National Water-Quality Assessment Program

Estimated Withdrawals from Stream-Valley Aquifers and Refined Estimated Withdrawals from Selected Aquifers in the United States, 2000
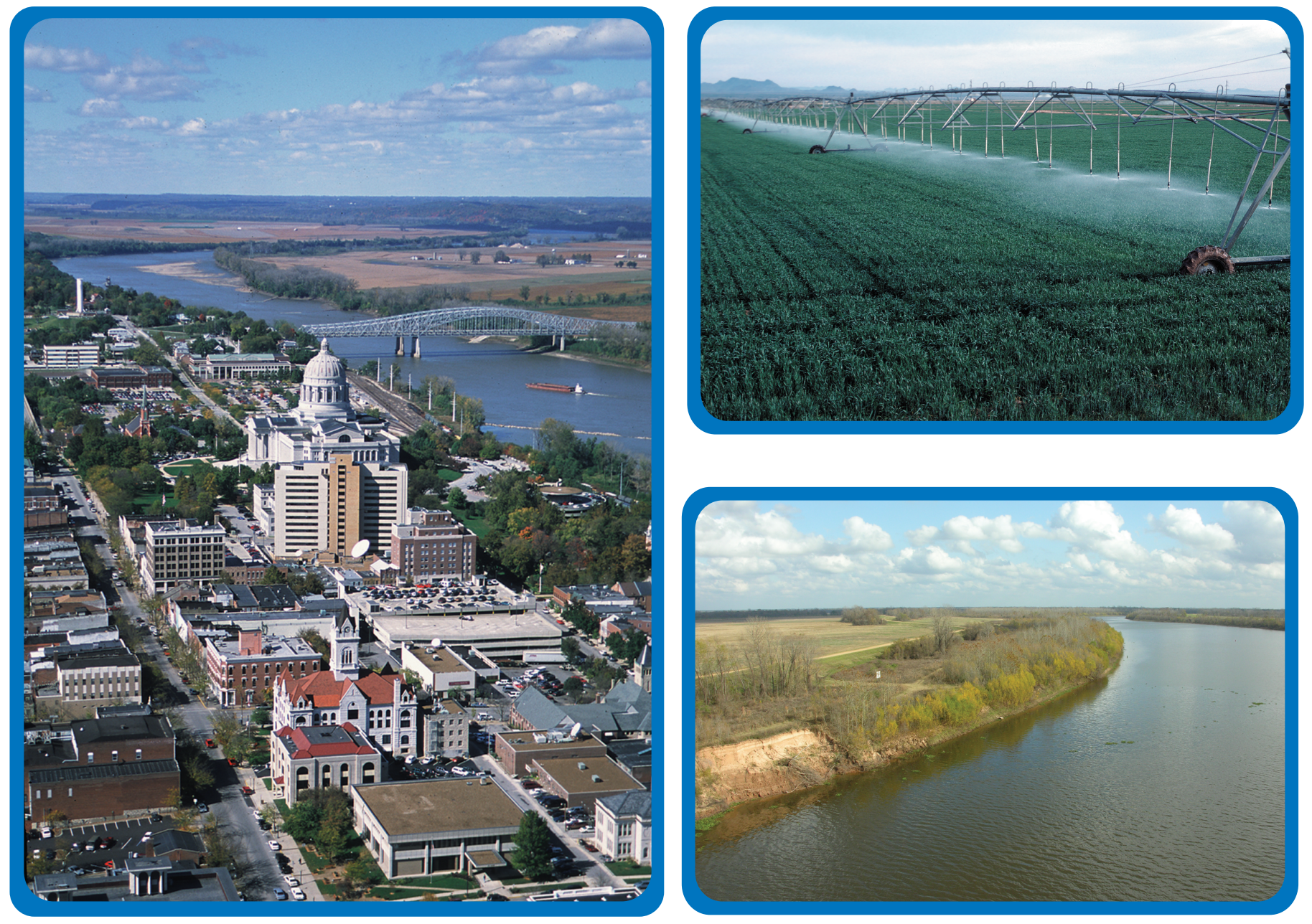

Scientific Investigations Report 2008-5003 


\section{Cover:}

Left: The Missouri River separates agriculture from the city life as it flows past the Missouri State Capitol in Jefferson City, Missouri (photograph by Sarah Minor, U.S. Department of Agriculture, Natural Resources Conservation Service, 2002).

Upper right: Center pivot irrigation on wheat growing in Yuma County, Colorado (photograph by Gene Alexander, U.S. Department of Agriculture, Natural Resources Conservation Service, 1987).

Lower right: View to the southwest showing the Red River alluvial valley at the Louisiana Highway 8 bridge near Boyce, Louisiana (photograph by Dennis K. Demcheck, U.S. Geological Survey, December 2007). 


\section{Estimated Withdrawals from Stream- Valley Aquifers and Refined Estimated Withdrawals from Selected Aquifers in the United States, 2000}

By B. Pierre Sargent, Molly A. Maupin, and Stephen R. Hinkle

National Water-Quality Assessment Program

Scientific Investigations Report 2008-5003 


\section{U.S. Department of the Interior DIRK KEMPTHORNE, Secretary}

\section{U.S. Geological Survey \\ Mark D. Myers, Director}

\section{U.S. Geological Survey, Reston, Virginia: 2008}

For product and ordering information:

World Wide Web: http://www.usgs.gov/pubprod

Telephone: 1-888-ASK-USGS

For more information on the USGS — the Federal source for science about the Earth, its natural and living resources, natural hazards, and the environment:

World Wide Web: http://www.usgs.gov

Telephone: 1-888-ASK-USGS

Any use of trade, product, or firm names is for descriptive purposes only and does not imply endorsement by the U.S. Government.

Although this report is in the public domain, permission must be secured from the individual copyright owners to reproduce any copyrighted materials contained within this report.

Suggested citation:

Sargent, B.P., Maupin, M.A., and Hinkle, S.R., 2008, Estimated withdrawals from stream-valley aquifers and refined estimated withdrawals from selected aquifers in the United States, 2000: U.S. Geological Survey Scientific Investigations Report 2008-5003, 71 p. 


\section{Foreword}

The U.S. Geological Survey (USGS) is committed to providing the Nation with credible scientific information that helps to enhance and protect the overall quality of life and that facilitates effective management of water, biological, energy, and mineral resources (http://www.usgs.gov/. Information on the Nation's water resources is critical to ensuring long-term availability of water that is safe for drinking and recreation and is suitable for industry, irrigation, and fish and wildlife. Population growth and increasing demands for water make the availability of that water, now measured in terms of quantity and quality, even more essential to the long-term sustainability of our communities and ecosystems.

The USGS implemented the National Water-Quality Assessment (NAWQA) Program in 1991 to support national, regional, State, and local information needs and decisions related to water-quality management and policy (http://water.usgs.gov/nawqa). The NAWQA Program is designed to answer: What is the condition of our Nation's streams and ground water? How are conditions changing over time? How do natural features and human activities affect the quality of streams and ground water, and where are those effects most pronounced? By combining information on water chemistry, physical characteristics, stream habitat, and aquatic life, the NAWQA Program aims to provide science-based insights for current and emerging water issues and priorities. From 1991-2001, the NAWQA Program completed interdisciplinary assessments and established a baseline understanding of water-quality conditions in 51 of the Nation's river basins and aquifers, referred to as Study Units (http://water.usgs.gov/nawqa/studyu.html).

In the second decade of the Program (2001-2012), a major focus is on regional assessments of water-quality conditions and trends. These regional assessments are based on major river basins and principal aquifers, which encompass larger regions of the country than the Study Units. Regional assessments extend the findings in the Study Units by filling critical gaps in characterizing the quality of surface water and ground water, and by determining status and trends at sites that have been consistently monitored for more than a decade. In addition, the regional assessments continue to build an understanding of how natural features and human activities affect water quality. Many of the regional assessments employ modeling and other scientific tools, developed on the basis of data collected at individual sites, to help extend knowledge of water quality to unmonitored, yet comparable areas within the regions. The models thereby enhance the value of our existing data and our understanding of the hydrologic system. In addition, the models are useful in evaluating various resource-management scenarios and in predicting how our actions, such as reducing or managing nonpoint and point sources of contamination, land conversion, and altering flow and (or) pumping regimes, are likely to affect water conditions within a region.

Other activities planned during the second decade include continuing national syntheses of information on pesticides, volatile organic compounds (VOCs), nutrients, selected trace elements, and aquatic ecology; and continuing national topical studies on the fate of agricultural chemicals, effects of urbanization on stream ecosystems, bioaccumulation of mercury in stream ecosystems, effects of nutrient enrichment on stream ecosystems, and transport of contaminants to public-supply wells.

The USGS aims to disseminate credible, timely, and relevant science information to address practical and effective water-resource management and strategies that protect and restore water quality. We hope this NAWQA publication will provide you with insights and information to meet your needs, and will foster increased citizen awareness and involvement in the protection and restoration of our Nation's waters.

The USGS recognizes that a national assessment by a single program cannot address all water-resource issues of interest. External coordination at all levels is critical for cost-effective management, regulation, and conservation of our Nation's water resources. The NAWQA Program, therefore, depends on advice and information from other agencies—Federal, State, regional, interstate, Tribal, and local—as well as nongovernmental organizations, industry, academia, and other stakeholder groups. Your assistance and suggestions are greatly appreciated.

Matthew C. Larsen Acting Associate Director for Water 


\section{Acknowledgments}

The authors gratefully acknowledge the cooperation of U.S. Geological Survey National Water Use Information Program contacts for state water-use information. They are identified, and contact information for them is listed on the World Wide Web at http://water.usgs.gov/watuse/wupersonnel. $h t m l$. Additional thanks are extended to personnel at state agencies who provided fresh groundwater withdrawal data or answered questions about aquifer extent and productivity, depth to water, or suitability of water quality for a specific water use. Wendy J. Danchuk, a cartographer at the U.S. Geological Survey, and Michael D. Kemppainen, a scientific illustrator at the U.S. Geological Survey, assisted with preparation of illustrations. 


\section{Contents}

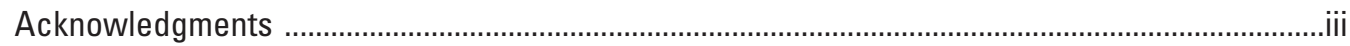

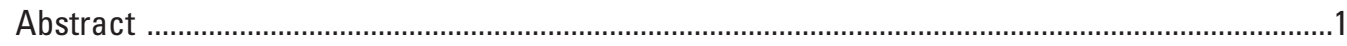

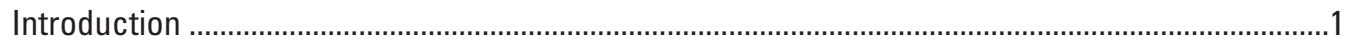

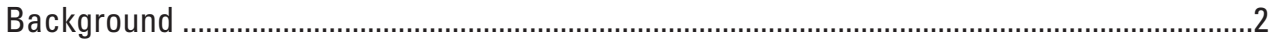

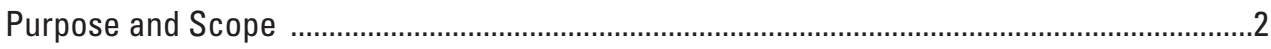

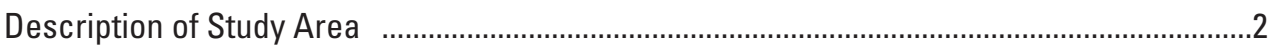

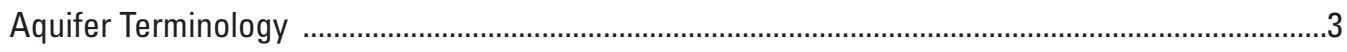

Approach and Estimation Methods ..........................................................................................5

Summary of Refined Estimated Withdrawals from Selected Aquifers in the United States,

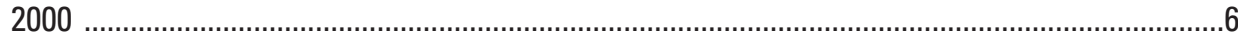

Estimated Withdrawals from Stream-Valley Aquifers ....................................................................6

States and the Commonwealth of Puerto Rico ....................................................................

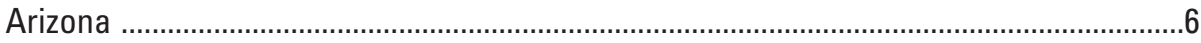

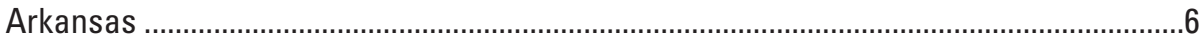

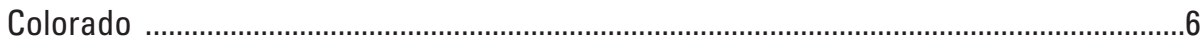

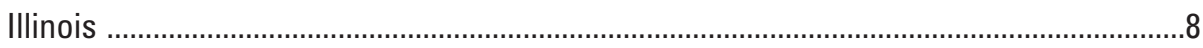

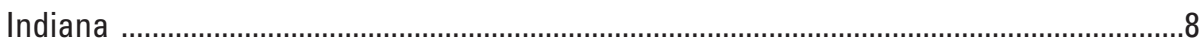

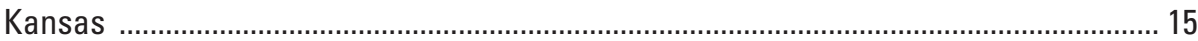

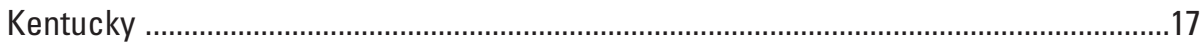

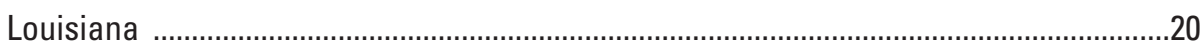

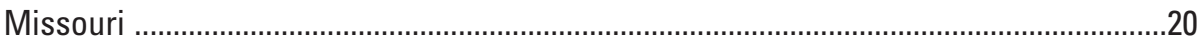

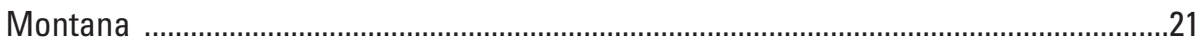

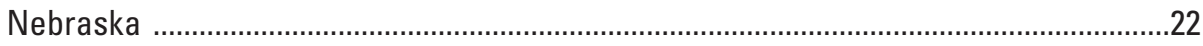

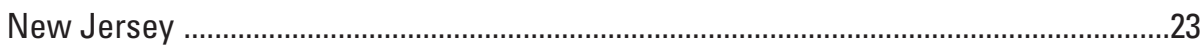

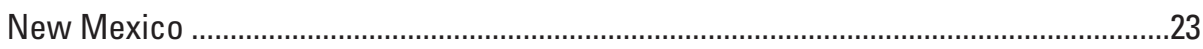

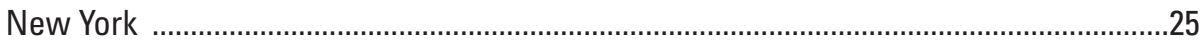

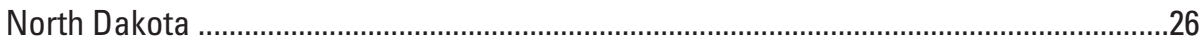

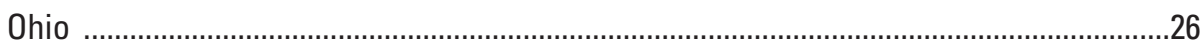

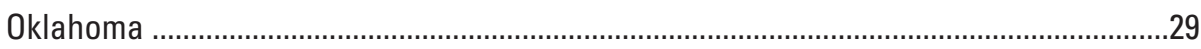

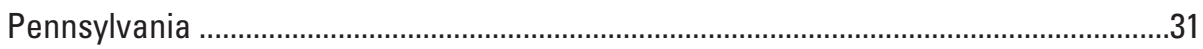

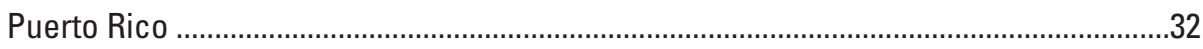

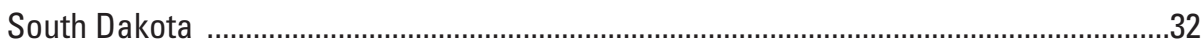

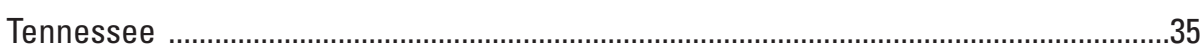

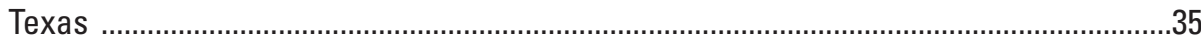

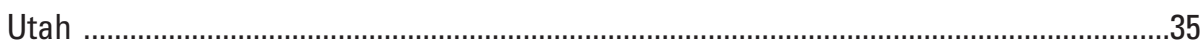

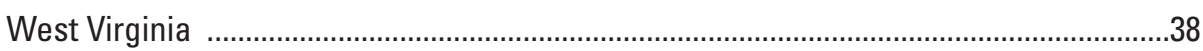

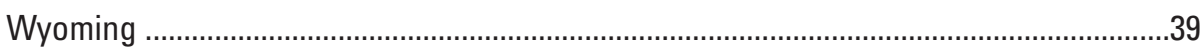

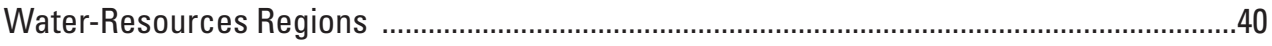

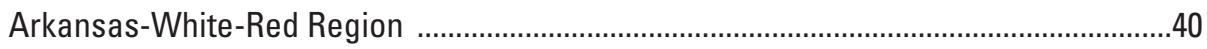

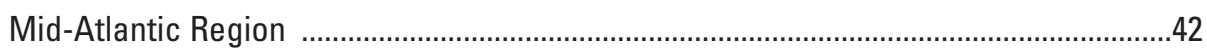

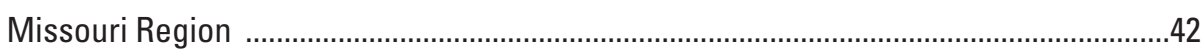

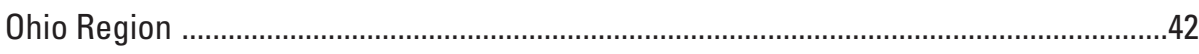




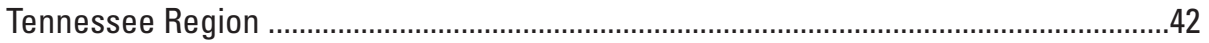

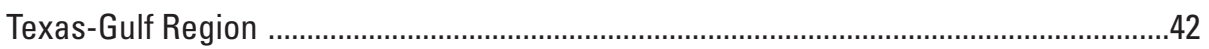

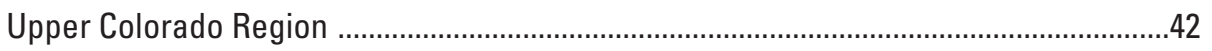

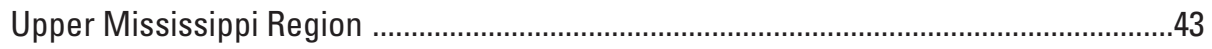

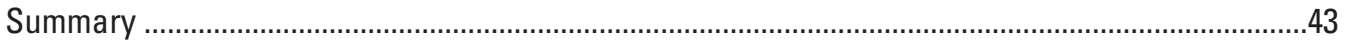

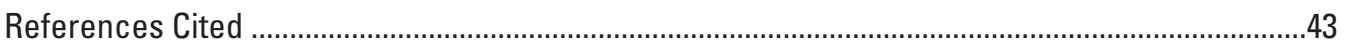

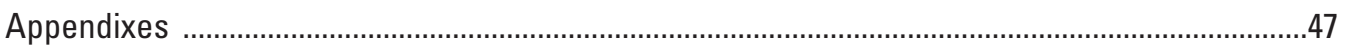

1. Sources of water-use and related information and methods of analysis, by state ........49

2. Estimated withdrawals for irrigation, public-supply, and self-supplied industrial uses from principal and Other aquifers in 24 States and the Commonwealth of Puerto Rico, 2000

3. Estimated withdrawals for irrigation, public-supply, and self-supplied industrial uses for aquifers and aquifer units disaggregated from withdrawals from Alluvial aquifers north of the extent of Quaternary continental glaciation in North Dakota, 2000

\section{Figures}

1. Map showing location of the study area in the contiguous United States and the Commonwealth of Puerto Rico

2. Diagrammatic section of hydrogeologic setting of two alluvial aquifers

3-22. Maps showing extent of:

3. Alluvial deposits in Arizona where stream-valley aquifer withdrawals were investigated

4. The Mississippi River Valley alluvial aquifer and other surficial alluvial aquifers along major rivers in Arkansas where withdrawals were associated with stream-valley aquifers

5. Alluvial deposits in Colorado where withdrawals from Alluvial and Other aquifers were associated with stream-valley aquifers

6. Alluvial deposits and the Mississippi River Valley alluvial aquifer in Illinois that were evaluated for possible withdrawals from stream-valley aquifers ..........18

7. Alluvial deposits in Indiana that were evaluated for possible withdrawals from stream-valley aquifers

8. Alluvial deposits in Kansas where withdrawals from Alluvial aquifers were associated with stream-valley aquifers

9. Alluvial deposits in Kentucky where withdrawals from Alluvial aquifers were associated with stream-valley aquifers

10. The Mississippi River Valley alluvial aquifer and the Red River alluvial aquifer in Louisiana where withdrawals from Alluvial aquifers were associated with stream-valley aquifers and other principal aquifers

11. Alluvial deposits in Missouri where withdrawals from Alluvial aquifers were associated with stream-valley aquifers

12. Alluvial deposits in Montana where withdrawals from Alluvial aquifers were associated with stream-valley aquifers

13. Alluvial deposits in Nebraska where withdrawals from Alluvial aquifers were associated with stream-valley aquifers 
14. Alluvial deposits in New Jersey where stream-valley aquifer withdrawals were investigated

15. Alluvial deposits in New Mexico where stream-valley aquifer withdrawals were investigated

16. Alluvial deposits in New York that were evaluated for possible withdrawals from stream-valley aquifers

17. Alluvial deposits in North Dakota where stream-valley aquifer withdrawals were investigated

18. Alluvial deposits in Ohio that were evaluated for possible withdrawals associated with stream-valley aquifers

19. Alluvial deposits along major streams in Oklahoma where withdrawals from Alluvial aquifers were associated with stream-valley aquifers

20. Alluvial deposits in Pennsylvania that were evaluated for possible withdrawals associated with stream-valley aquifers

21. Aquifers in the Commonwealth of Puerto Rico where stream-valley aquifer withdrawals were investigated

22. Coarse-grained glacial deposits, stream-valley alluvium, and basin fill in South Dakota where withdrawals from Alluvial aquifers were associated with stream-valley aquifers

23. Map showing the surficial aquifer system in Tennessee that consists mainly of the Mississippi River Valley alluvial aquifer.

24-27. Maps showing extent of:

24. Alluvial deposits along major streams in Texas where withdrawals from Alluvial aquifers were associated with stream-valley aquifers

25. Alluvial deposits in Utah where withdrawals from Alluvial aquifers were associated with stream-valley aquifers

26. Alluvial deposits in West Virginia where withdrawals from Alluvial aquifers were associated with stream-valley aquifers

27. Stream-valley alluvium and basin-fill deposits in Wyoming where withdrawals from Alluvial aquifers were associated with stream-valley aquifers

28. Map showing water-resources regions of the United States

\section{Tables}

1. Summary of original and revised estimated withdrawals from principal and Other aquifers, and estimated withdrawals attributed to stream-valley aquifers

2. Total estimated withdrawals from stream-valley aquifers associated with major rivers, by state, 2000

3. Estimated withdrawals for irrigation, public-supply, and self-supplied industrial uses from stream-valley aquifers associated with major rivers and principal aquifers in 20 States, 2000

4. Distribution of estimated withdrawals for irrigation, public-supply, and selfsupplied industrial uses from aquifers and water-bearing units disaggregated from withdrawals from Other aquifers in 10 States, 2000

5. Estimated withdrawals from stream-valley aquifers associated with major rivers, creeks, and areas by water-resources region, 2000 


\section{Conversion Factors and Datum}

\begin{tabular}{lcl}
\hline \multicolumn{1}{c}{ Multiply } & By & \multicolumn{1}{c}{ To obtain } \\
\hline mile $(\mathrm{mi})$ & Length & \\
\hline & 1.609 & kilometer $(\mathrm{km})$ \\
\hline acre & Area & \\
acre & 43,560 & square foot $\left(\mathrm{ft}^{2}\right)$ \\
acre & 4,047 & square meter $\left(\mathrm{m}^{2}\right)$ \\
\hline & 0.001562 & square mile $\left(\mathrm{mi}^{2}\right)$ \\
\hline gallon & Volume & \\
\hline & 3.785 & liter $(\mathrm{L})$ \\
\hline gallon per minute $(\mathrm{gal} / \mathrm{min})$ & Flow rate & \\
gallon per day $(\mathrm{gal} / \mathrm{d})$ & 0.06309 & liter per second $(\mathrm{L} / \mathrm{s})$ \\
million gallons per day $(\mathrm{Mgal} / \mathrm{d})$ & 3.785 & liter per day \\
& 1.121 & thousand acre-feet per year \\
& 0.001547 & thousand cubic feet per second \\
& 0.6944 & thousand gallons per minute \\
& 0.003785 & million cubic meters per day \\
& 1.3815 & million cubic meters per year \\
\hline
\end{tabular}

Horizontal coordinate information is referenced to the North American Datum of 1927 (NAD 27). 


\title{
Estimated Withdrawals from Stream-Valley Aquifers and Refined Estimated Withdrawals from Selected Aquifers in the United States, 2000
}

\author{
By B. Pierre Sargent, Molly A. Maupin, and Stephen R. Hinkle
}

\section{Abstract}

The U.S. Geological Survey National Water Use Information Program compiles estimates of fresh groundwater withdrawals in the United States on a 5-year interval. In the year-2000 compilation, withdrawals were reported from principal aquifers and aquifer systems including two general aquifers-Alluvial and Other aquifers. Withdrawals from a widespread aquifer group — stream-valley aquiferswere not specifically identified in the year-2000 compilation, but they are important sources of ground water. Stream-valley aquifers are alluvial aquifers located in the valley of major streams and rivers. Stream-valley aquifers are long but narrow aquifers that are in direct hydraulic connection with associated streams and limited in extent compared to most principal aquifers.

Based in large part on information published in U.S. Geological Survey reports, preliminary analysis of withdrawal data and hydrogeologic and surface-water information indicated areas in the United States where possible stream-valley aquifers were located. Further assessment focused on 24 states and the Commonwealth of Puerto Rico. Withdrawals reported from Alluvial aquifers and (or) Other aquifers in 22 states and the Commonwealth of Puerto Rico were investigated. Two additional States-Arkansas and New Jersey-were investigated because withdrawals reported from other principal aquifers in these two States may have been from stream-valley aquifers.

Withdrawals from stream-valley aquifers were identified in 20 States and were 1,560 Mgal/d (million gallons per day), a rate comparable to withdrawals from the 10th most productive principal aquifer in the United States. Of the $1,560 \mathrm{Mgal} / \mathrm{d}$ of withdrawals attributed to stream-valley aquifers, 1,240 $\mathrm{Mgal} / \mathrm{d}$ were disaggregated from Alluvial aquifers, $150 \mathrm{Mgal} / \mathrm{d}$ from glacial sand and gravel aquifers, $116 \mathrm{Mgal} / \mathrm{d}$ from Other aquifers, $28.1 \mathrm{Mgal} / \mathrm{d}$ from Pennsylvanian aquifers, and $24.9 \mathrm{Mgal} / \mathrm{d}$ from the Mississippi River Valley alluvial aquifer. Five States, including Colorado (552 Mgal/d), Kansas (384 Mgal/d), Oklahoma (126 Mgal/d), Kentucky (102 Mgal/d), and Ohio (100 Mgal/d), accounted for 81 per- cent of estimated stream-valley aquifer withdrawals identified in this report. Of the total withdrawals from stream-valley aquifers, about 63 percent $(984 \mathrm{Mgal} / \mathrm{d})$ were used for irrigation, 26 percent (400 Mgal/d) for public-supply, and 11 percent (177 Mgal/d) for self-supplied industrial uses. The largest estimated water withdrawals were from streamvalley aquifers associated with the South Platte (404 Mgal/d), Arkansas (395 Mgal/d), and Ohio (221 Mgal/d) Rivers.

\section{Introduction}

The U.S. Geological Survey (USGS) National Water Use Information Program (NWUIP) compiles estimates of fresh ground-water withdrawals in the United States on a 5-year interval. Water-use reports that present the compilations are accessible on the World Wide Web (online) at $h$ ttp:// water.usgs.gov/watuse/50years.html, and the compilation data grouped by county and watershed are accessible at $h t t p: / /$ water.usgs.gov/watuse/. In this report, the compilation of interest is for the year 2000 and is referred to as the 2000 compilation. As part of the 2000 compilation, the USGS estimated ground-water withdrawals for 66 principal aquifers and aquifer systems and an Other $^{1}$ aquifer group. The Other aquifer group includes withdrawals from aquifers that were not included in one of the principal aquifers. The resulting publication, "Estimated Withdrawals from Principal Aquifers in the United States, 2000" (Maupin and Barber, 2005), which is accessible online at http://pubs.usgs.gov/circ/2005/1279, includes estimated freshwater withdrawals for the water-use categories of irrigation, public supply, and self-supplied industrial. The three categories of use represented 92 percent of total groundwater use in the United States in 2000 (Maupin and Barber, 2005).

Most of the principal aquifers and aquifer systems are equivalent to major aquifers and aquifer systems described

\footnotetext{
${ }^{1}$ The specific term Other aquifers, denoted with italics, is used to refer to withdrawals from various miscellaneous aquifers and water-bearing units reported as "Other" aquifers by Maupin and Barber (2005).
} 
by Miller (2000) in the "Ground Water Atlas of the United States" (hereafter called the atlas) and are depicted on the map of the "Principal Aquifers of the 48 conterminous United States, Hawaii, Puerto Rico, and the U.S. Virgin Islands" (hereafter called the principal aquifer map) (U.S. Geological Survey, 2003). Although Alluvial ${ }^{2}$ and Other aquifers (Maupin and Barber, 2005) are not shown on the principal aquifer map, large withdrawals were assigned to these two general aquifers. Stream-valley aquifers were not specifically identified by Maupin and Barber (2005); however, the NWUIP recognized the importance of stream-valley aquifer withdrawals. The aquifer group, Alluvial aquifers, was expected to include withdrawals from stream-valley aquifers and other alluvial materials.

Withdrawals from the Alluvial (1,800 Mgal/d [million gallons per day]) and Other (1,160 Mgal/d) aquifers were the 10th and 11th largest, respectively, within the ranking of total withdrawals from the 67 aquifers and aquifer systems in the United States in 2000 (Maupin and Barber, 2005). Further investigation of withdrawals from Alluvial and Other aquifers was needed to (1) improve the knowledge of regional water availability and use, and (2) refine (disaggregate and redistribute) withdrawals assigned to Alluvial and Other aquifers to determine whether another potentially important aquifer group - stream-valley aquifers-provides substantial amounts of freshwater for irrigation, public-supply, and self-supplied industrial uses.

\section{Background}

Identification and compilation of withdrawals from stream-valley aquifers will provide information useful to water managers and the USGS water-resources monitoring and assessment programs. In particular, refined water-withdrawal data will assist the USGS National Water-Quality Assessment (NAWQA) Program in addressing its long-term goals: the description of the status and trends in the quality of a large, representative part of the Nation's surface and ground-water resources, and the identification of the major natural and human factors that affect the quality of these resources. In 2001, the NAWQA Program began ground-water investigations that focused on regional assessments based on a framework of principal aquifers that provide the majority of water used in the United States (Lapham and others, 2005). The studies included 19 of the principal aquifers (Lapham and others, 2005) shown on the principal aquifer map (U.S. Geological Survey, 2003). The criteria for selecting the 19 study sites included the analysis of withdrawals from aquifers described by the NWUIP, which provided a means to prioritize and rank principal aquifers and aquifer systems on the basis of total

\footnotetext{
${ }^{2}$ In this report, the general term "alluvial aquifers" refers to unconsolidated sand and gravel aquifers that typically consist of sediments deposited by rivers and streams. The term Alluvial aquifers denoted with italics, refers to withdrawals from alluvial-type deposits that were not represented in any other aquifer or aquifer system, as reported by Maupin and Barber (2005).
}

annual withdrawals. Withdrawal estimates from stream-valley aquifers will improve the knowledge of the nature and locations of the specific aquifers represented by Alluvial and Other aquifers in Maupin and Barber (2005), and will further assist the NAWQA Program in its overall evaluation of groundwater-quality assessments of aquifers that provide the largest withdrawals nationwide. In 2004, the NAWQA Program began a study of withdrawals from Alluvial and Other aquifers described in Maupin and Barber (2005) to determine whether any withdrawal amount could be reassigned to stream-valley aquifers or various other relatively less important (local or regional) aquifers.

\section{Purpose and Scope}

This report describes estimated fresh ground-water withdrawals for irrigation, public-supply, and self-supplied industrial uses from stream-valley aquifers in the United States for the year 2000, which were refined from estimated withdrawals from Alluvial aquifers, selected principal aquifers, and Other aquifers described by Maupin and Barber (2005). The report includes a summary of estimated stream-valley aquifer withdrawals at the state level and a brief national overview of the results of this investigation. Discussions, maps, and tables, grouped by states and water-resources regions, provide an understanding of the distribution of withdrawals from specific stream-valley aquifers. The section presented by states includes (for each state) a brief description of efforts to refine the data and tabulated withdrawals for the three water-use categories; supporting information on each state's sources of data for the 2000 compilation is included in appendix 1 . The relative importance of withdrawals from Alluvial and Other aquifers in comparison to withdrawals from other principal aquifers within a state is discussed. The section presented by water-resources regions includes tabulated withdrawals within the USGS two-digit hydrologic unit codes (HUC's) (Seaber and others, 1987).

The data presented represent the amount of water withdrawn from aquifers at the point of the well. There are no double-accounted withdrawals for a stream-valley aquifer. In this report, the amount of water withdrawn from a stream-valley aquifer and reported by a state is not included in a reported value for another state with a stream-valley aquifer of the same name. An interbasin transfer of water from stream-valley aquifers can not be determined from the data collected. The estimated withdrawals are rounded to three significant figures. All values are rounded independently; therefore, the sums of individual rounded numbers may not equal the totals. Appendix 2 lists selected water-withdrawal data from Maupin and Barber (2005) that are used in the current report.

\section{Description of Study Area}

Twenty-four states and the Commonwealth of Puerto Rico (Puerto Rico) are included in the study area (fig. 1). 


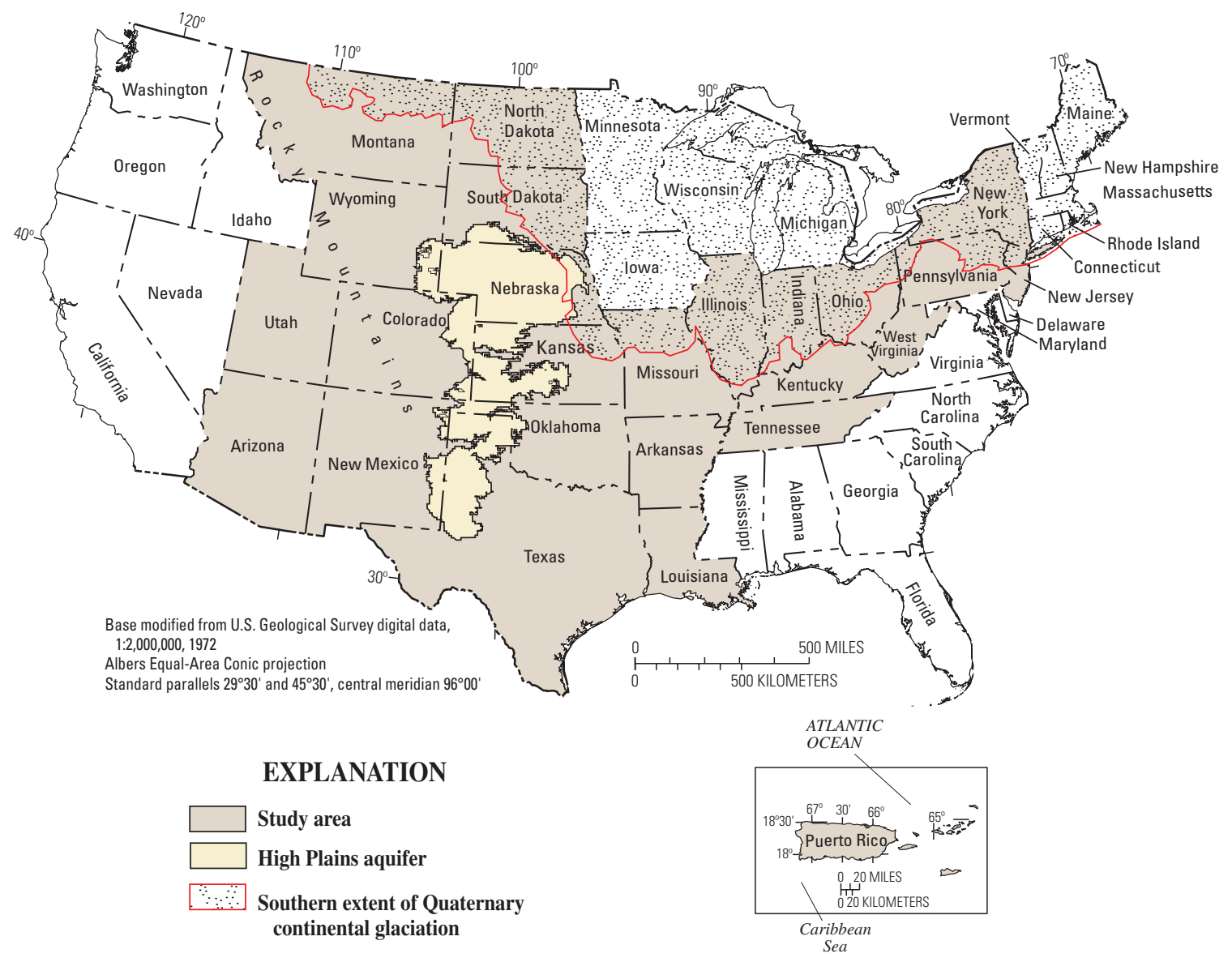

Figure 1. Location of the study area in the contiguous United States and the Commonwealth of Puerto Rico.

These states and Puerto Rico were identified as areas where stream-valley aquifer withdrawals could be present based in large part on the atlas (Miller, 2000). Many of these states and Puerto Rico reported withdrawals for Alluvial and/or Other aquifers in 2000 (Maupin and Barber, 2005). Withdrawals from Alluvial aquifers were reported for 16 States-Colorado, Kansas, Kentucky, Louisiana, Missouri, Montana, North Dakota, Nebraska, Ohio, Oklahoma, South Dakota, Tennessee, Texas, Utah, West Virginia, and Wyoming. Six additional States-Arizona, Illinois, Indiana, New Mexico, New York, and Pennsylvania and Puerto Rico-reported 2000 withdrawals from Other aquifers (Maupin and Barber, 2005). Two States-Arkansas and New Jersey-were investigated because information presented in the atlas (Miller, 2000) indicated the possible presence of stream-valley aquifers.

The study area generally excluded areas that lie completely within the maximum extent of Quaternary continental glaciation, areas west of the Rocky Mountain/Colorado Plateau region, and areas coincident with the North Atlantic Coastal Plain aquifer systems, Basin and Range basin-fill aquifers, and Northern Rocky Mountains Intermontane Basins aquifer system (U.S. Geological Survey, 2003). Within the study area, the areal extent of the High Plains aquifer and glaciated areas also were excluded from the investigation (fig. 1). In these excluded areas, stream-valley aquifers and their withdrawals typically cannot be differentiated from other principal aquifers consisting of the same types of lithologic materials.

\section{Aquifer Terminology}

A principal aquifer, as used in this report and in the principal aquifer map of the National Atlas of the United States (U.S. Geological Survey, 2003), is defined as a regionally extensive aquifer or aquifer system that has the potential to be used as a source of potable water. Alluvial aquifers and glacial sand and gravel aquifers are considered principal aquifers (U.S. Geological Survey, 2003; Maupin and Barber, 2005). Alluvial aquifers consist of sediments deposited by rivers and streams that are present in or near existing major streams (Maupin and Barber, 2005), but the aquifers also include terrace deposits and unconsolidated sediments deposited by ancient streams. Some eolian deposits or 
wind-blown sediments in Colorado were included in Alluvial aquifers (Maupin and Barber, 2005). For the purpose of this report, stream-valley aquifers are alluvial sand and gravel aquifers that are in direct hydraulic connection with an existing stream or river. Stream-valley aquifers are similar to alluvial-valley aquifers described by Rosenshein (1988, p. 174) and alluvial valleys described by Heath (1984, p. 59). Rosenshein (1988) defined alluvial-valley aquifers to be long but narrow aquifers that "are in hydraulic connection with associated streams," and that "are of limited areal extent in comparison to most aquifer systems, [but] they are among the most intensively used." Heath (1984, p. 58) defined alluvial valleys as "thick sand and gravel deposits beneath floodplains and terraces of streams." Heath (1984, p. 59) used three criteria to distinguish alluvial valleys. These criteria are as follows:

1. The valleys contain sand and gravel deposits thick enough to supply water to wells at moderate to large rates. [Commonly, the water-transmitting capacity of the sand and gravel is at least 10 times larger than that of the adjacent (enclosing) rocks.]

2. The sand and gravel deposits are in hydraulic contact with a perennial stream which serves as a source of recharge and whose flow normally far exceeds the demand from any typical well field.

3. The sand and gravel deposit occurs in a clearly defined band ('channel') that normally does not extend beyond the floodplain and adjacent terraces. (In other words, the width of the deposit is small or very small compared with its length.)
Figure 2 shows two hydrogeologic settings that illustrate the nature of stream-valley aquifers. On the left side of the figure, the sand and gravel aquifer is clearly defined within the alluvial floodplain and in hydraulic contact with the river. Recharge to wells screened in the alluvial floodplain is provided directly by precipitation or by infiltration from the river. This setting meets some of the criteria for stream-valley aquifer designation. On the right side of figure 2, the sand and gravel deposits in a buried river valley may have watertransmitting capacity greater than adjacent rocks, but recharge is reduced to the volume that passes through the overlying clay and silt. There is no direct hydraulic connection to an existing river. The setting on the right side of the figure does not meet the criteria for stream-valley aquifer designation but the sediments deposited by ancient streams may transmit sufficient water to wells to be classified as an alluvial aquifer.

In the atlas, stream-valley aquifers are defined as alluvial aquifers "located beneath channels, floodplains, and terraces in the valleys of major streams" (Miller, 2000, p. A6). Miller (2000) further states that, "stream-valley aquifers are not shown [on the principal aquifer map] because they are too small to map accurately at the scale of the figure." However, the most important stream-valley aquifers are mapped in the further descriptive atlas chapters and provide a guide for this investigation.

Glacial sand and gravel aquifers are unconsolidated deposits of sand, gravel, and silt and clay located north of the limit of Quaternary continental glaciation and east of the Rocky Mountains. Large areas of North America were subjected to episodes of continental glacial advances and retreats over millions of years. After each retreat, the glaciers left thick sequences of sediments (collectively called glacial

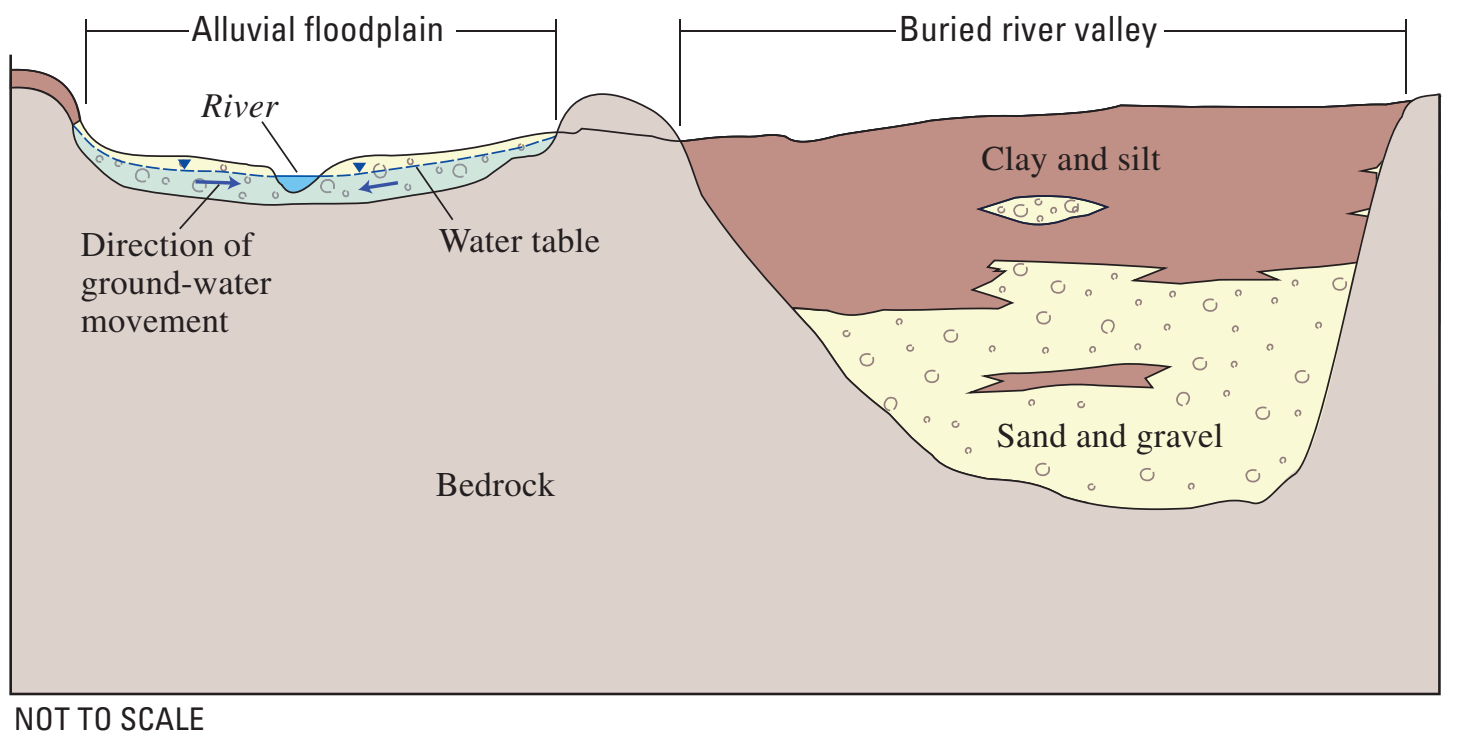

Figure 2. Diagrammatic section of hydrogeologic setting of two alluvial aquifers. The alluvial aquifer on the left meets the definition of a stream-valley aquifer, but the alluvial aquifer on the right does not. 
drift) in basins and valleys. Materials deposited by the glacial ice may vary in size from clay to boulders and be unsorted and unstratified. Vast amounts of fluvial material (glacial outwash) were carried away from the glaciers by streams and rivers originating from the melting glaciers. Over time, more recent (Holocene) alluvial deposits were deposited and reworked. Glacial sand and gravel aquifers often are not distinguishable from overlying stream-valley aquifers that are present beneath and along rivers and streams.

\section{Approach and Estimation Methods}

In this report, ground-water withdrawals reported from Alluvial and Other aquifers in Maupin and Barber (2005) that meet the definition of stream-valley aquifers are identified. Residual Alluvial aquifer withdrawals from deposits that do not fit the definition of a stream-valley aquifer also are identified. Elevated terrace deposits in Oklahoma and eolian sand and isolated terrace deposits in Colorado are examples of deposits that do not meet the definition of a stream-valley aquifer although they are considered Alluvial aquifers in this report.

There are instances where withdrawals were reclassified based upon this analysis. For example, some year-2000 withdrawals from counties south of the extent of Quaternary continental glaciation previously assigned to glacial sand and gravel aquifers (Maupin and Barber, 2005) were reclassified as stream-valley aquifer withdrawals. If withdrawals from Alluvial or Other aquifers could not be disaggregated and assigned to a specific aquifer or aquifer system, the withdrawals remained assigned to Alluvial or Other aquifers. Thus estimated withdrawals from stream-valley aquifers associated with specific rivers, creeks, or areas represent a minimum estimate. Nevertheless, this estimate provides a quantitative assessment on their importance and, as such, this estimate may be useful for researchers evaluating ground-water resources at regional and national scales.

All data and supporting information were gathered from USGS offices or state agencies. Supporting information includes, for example, owner name, county, aquifer extent, eight-digit HUC, well location, well depth, and well diameter. Water-use and ground-water data used to assign withdrawals to aquifers were obtained from USGS water-use specialists in states in the study area. Sources and details of the data provided by the specialists are listed in appendix 1. Additional data for selected states were obtained from the USGS National Water Information System Ground-Water Site-Inventory System (GWSI) data base (U.S. Geological Survey, 1998). Potential sources of water-use information and guidelines for estimating water use for the 2000 compilation are described by Kenny (2004).

Maps in the atlas show the areal extent of streamvalley aquifers from which withdrawals could be estimated. USGS HUC maps (Seaber and others, 1987) and state watershed maps were used to assign stream-valley aquifer withdrawals to river basins and water-resources regions. In general, if the information was available, the smallestsize tributary name was used to designate a stream-valley aquifer.

The estimation of stream-valley aquifer withdrawals required the collecting, assessing, and joining of water-use, ground-water, and surface-water data. Water-use data typically included withdrawal rate, water source (ground water or surface water), category (irrigation, public supply, or self-supplied industrial), and Standard Industrial Classification (SIC) code (Office of Management and Budget, 1987). Ground-water data typically included well identifier, well location, aquifer unit of the screened interval, well use, well owner, well depth, well status, and well permit number. Surface-water data typically included river name, HUC's, and state watershed name. Because this was a multistate study, all data characterization had to be equivalent across state lines. In states where water-use data were assigned a SIC code, the SIC code was used to separate industrial from commercial water use, and to make comparable the self-supplied industrial water use throughout the study area.

A combination of site-specific and aggregate (non-site specific) data were available. Site-specific data include locations of individual wells or facilities where water is withdrawn. Aggregate data do not include specific locations of wells or facilities. Data are grouped by area, such as a county or watershed. In some states, water-use data (withdrawal rate, source, and use) were aggregated at the county level, but ground-water data (wells and associated data) were site specific.

Two analytical methods were used to estimate streamvalley aquifer withdrawals. The site-specific method was used to link water-use, ground-water, and surface-water data sets to specific locations. Using this method, withdrawals from each well can be grouped by location or other attributes, and totaled to estimate stream-valley aquifer withdrawals. The locations of some wells were compared with maps of watersheds and aquifers to determine stream-valley aquifer withdrawals.

An aggregate method was applied when site specific data were not available. The aggregate method typically was used to estimate withdrawals by making an assumption about the data and using knowledge of an area. In some states, a combination of both methods (aggregate and site specific) was used to estimate withdrawals. For example, withdrawal rates at individual irrigation wells in a county were not known, but ground-water withdrawals for irrigation were estimated based on county crop acreage and irrigation application rates (aggregate data) (Kenny, 2004). If the atlas indicates that only one stream-valley aquifer is present and no other alluvial deposits are present in the county, and well data indicate all irrigation wells are shallow and screened in alluvial material, the decision was made to assign all irrigation withdrawals in the county to the stream-valley aquifer. 


\section{Summary of Refined Estimated Withdrawals from Selected Aquifers in the United States, 2000}

The analysis and disaggregation of ground-water withdrawals from Alluvial aquifers, selected principal aquifers, and Other aquifers as published in Maupin and Barber (2005) resulted in the identification of withdrawals of $1,560 \mathrm{Mgal} / \mathrm{d}$ from stream-valley aquifers in 20 states (table 1). This withdrawal rate is comparable to withdrawals from the 10th most productive principal aquifer in the United States (Maupin and Barber, 2005). Of the withdrawals attributed to streamvalley aquifers, 1,240 Mgal/d were disaggregated from Alluvial aquifers, $150 \mathrm{Mgal} / \mathrm{d}$ from glacial sand and gravel aquifers, $116 \mathrm{Mgal} / \mathrm{d}$ from Other aquifers, $28.1 \mathrm{Mgal} / \mathrm{d}$ from Pennsylvanian aquifers, and $24.9 \mathrm{Mgal} / \mathrm{d}$ from the Mississippi River Valley alluvial aquifer.

Ground-water withdrawals from stream-valley aquifers for each state are listed in table 2, which indicates that Colorado (552 Mgal/d), Kansas (384 Mgal/d), Oklahoma (126 Mgal/d), Kentucky (102 Mgal/d), and Ohio (100 Mgal/d) accounted for most (81 percent) of the total withdrawals from stream-valley aquifers. Of this total, $984 \mathrm{Mgal} / \mathrm{d}$ (63 percent) was for irrigation, $400 \mathrm{Mgal} / \mathrm{d}$ (26 percent) for public supply, and $177 \mathrm{Mgal} / \mathrm{d}$ (11 percent) for self-supplied industrial uses. The largest estimated water withdrawals were from streamvalley aquifers associated with the South Platte (404 Mgal/d), Arkansas (395 Mgal/d), and Ohio (221 Mgal/d) Rivers.

\section{Estimated Withdrawals from Stream- Valley Aquifers}

\section{States and the Commonwealth of Puerto Rico}

Withdrawals for irrigation, public supply, and selfsupplied industrial uses from Alluvial and Other aquifers in each state in the study area were analyzed and, where applicable, assigned to stream-valley aquifers (table 3 ). Twenty states were determined to have withdrawals from stream-valley aquifers. In some states, such as Louisiana, a portion of withdrawals from Alluvial aquifers were determined to be attributable to other principal aquifers, and the withdrawals were reassigned (table 1). Where possible, withdrawals from Other aquifers were disaggregated to withdrawals from specific aquifers or aquifer systems. The results of the disaggregation of Other aquifers are tabulated in table 4 , by state, aquifer or waterbearing unit, and water-use category.

\section{Arizona}

In 2000, total ground-water withdrawals for all categories of use in Arizona were about 3,420 Mgal/d (Hutson and others, 2004). About 95 percent of the withdrawals (3,240 Mgal/d) were for public-supply, self-supplied industrial, and irrigation uses, and were assigned to three principal and Other aquifers (Maupin and Barber, 2005) (appendix 2). No withdrawals were assigned to Alluvial aquifers in Arizona in 2000. Withdrawals from Other aquifers (88.2 Mgal/d) accounted for about 3 percent of the withdrawals from principal and Other aquifers in Arizona and were used for public supply (58.3 Mgal/d) and irrigation (29.9 Mgal/d) (appendix 2). No withdrawals from Other aquifers could be attributed to stream-valley aquifers in Arizona. All Other aquifer withdrawals were attributed to withdrawals in the Central Highlands Province (fig. 3).

\section{Arkansas}

In 2000, total ground-water withdrawals for all categories of use in Arkansas were 6,920 Mgal/d (Hutson and others, 2004). About 97 percent $(6,710 \mathrm{Mgal} / \mathrm{d})$ of the withdrawals were for public-supply, self-supplied industrial, and irrigation uses, and were assigned to four principal aquifers, including the Mississippi River Valley alluvial aquifer (Maupin and Barber, 2005) (fig. 4, appendix 2). Estimated withdrawals from the Mississippi River Valley alluvial aquifer were $6,370 \mathrm{Mgal} / \mathrm{d}$, including $6,320 \mathrm{Mgal} / \mathrm{d}$ for irrigation, $40.5 \mathrm{Mgal} / \mathrm{d}$ for public-supply, and $5.74 \mathrm{Mgal} / \mathrm{d}$ for selfsupplied industrial uses (appendix 2). No withdrawals were assigned to Alluvial or Other aquifers in Arkansas in 2000 (Maupin and Barber, 2005).

Withdrawals of $24.9 \mathrm{Mgal} / \mathrm{d}$ in Arkansas were reassigned from the Mississippi River Valley alluvial aquifer to stream-valley aquifers associated with the Red (17.5 Mgal/d), Arkansas (7.22 Mgal/d), and Ouachita-Saline Rivers (0.21 Mgal/d) (fig. 4, table 3). About 77 percent (19.1 Mgal/d) of the withdrawals were for irrigation. The reassignment reduced withdrawals from the Mississippi River Valley alluvial aquifer for the three water-use categories by less than 1 percent to 6,350 Mgal/d (table 1).

\section{Colorado}

In 2000, total ground-water withdrawals for all categories of use in Colorado were about 2,320 Mgal/d (Hutson and others, 2004). About 96 percent $(2,230 \mathrm{Mgal} / \mathrm{d})$ of the withdrawals were for public-supply, self-supplied industrial, and irrigation uses, and were assigned to five principal and Other aquifers (Maupin and Barber, 2005) (appendix 2). Withdrawals from Alluvial (496 Mgal/d) and Other (114 Mgal/d) aquifers accounted for 27 percent of the withdrawals from principal aquifers and Other aquifers (appendix 2). Withdrawals were mostly for irrigation from Alluvial aquifers (482 Mgal/d), and to a lesser degree from Other aquifers (89.4 Mgal/d) (appendix 2).

A total of $552 \mathrm{Mgal} / \mathrm{d}, 478 \mathrm{Mgal} / \mathrm{d}$ from Alluvial aquifers and about 73.9 Mgal/d from Other aquifers (table 1), were 
Table 1. Summary of original (Maupin and Barber, 2005) and revised estimated withdrawals from principal and Other aquifers, and estimated withdrawals attributed to stream-valley aquifers.

[Values have been rounded]

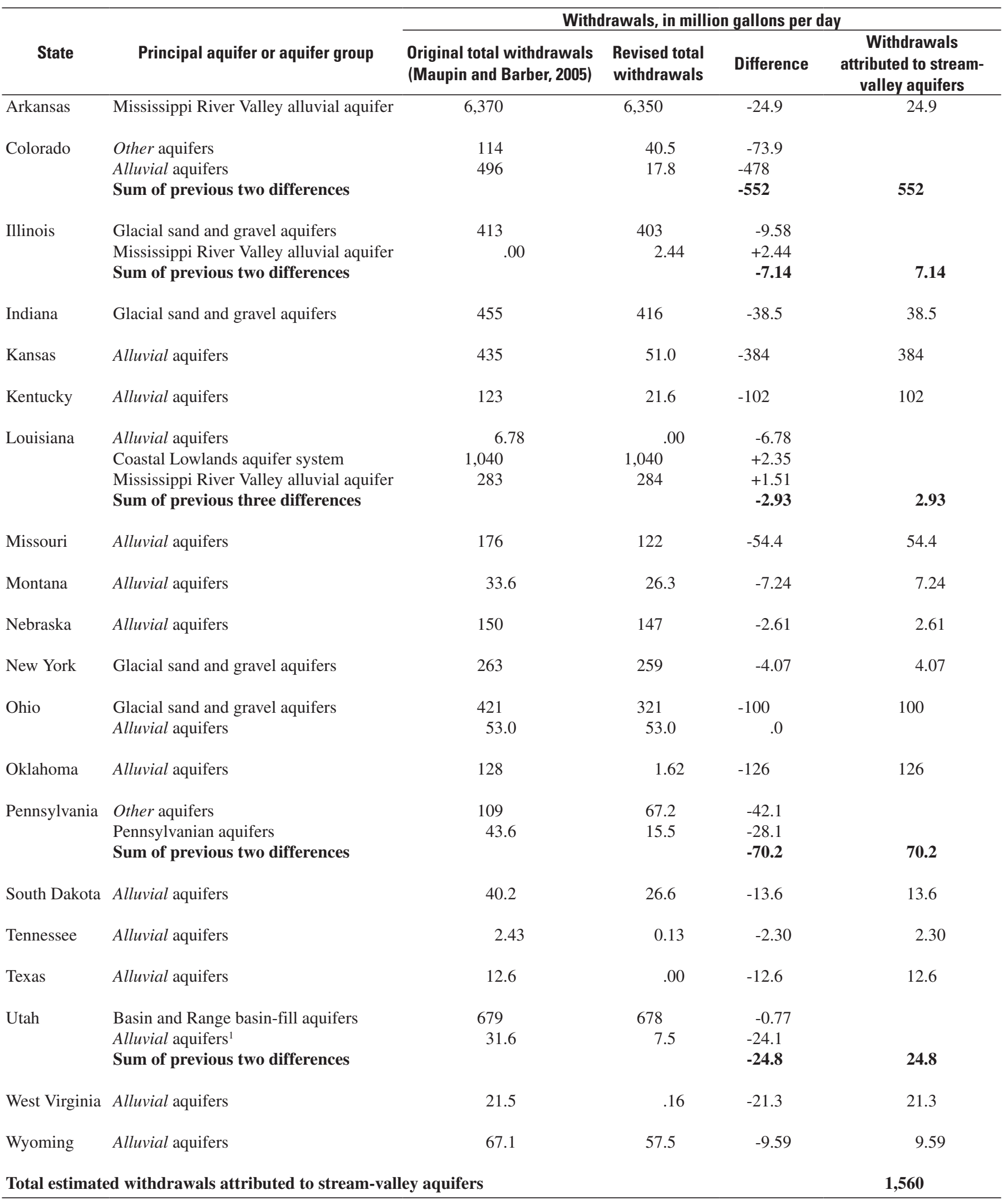

\footnotetext{
${ }^{1}$ Withdrawals of $0.77 \mathrm{Mgal} / \mathrm{d}$ from Basin and Range basin-fill aquifers were reassigned to Alluvial aquifers in Utah.
} 
Table 2. Total estimated withdrawals from stream-valley aquifers associated with major rivers, by state, 2000.

[Values have been rounded]

\begin{tabular}{|lc}
\hline State & $\begin{array}{c}\text { Total estimated withdrawals, } \\
\text { in million gallons per day }\end{array}$ \\
\hline Arkansas & 24.9 \\
\hline Colorado & 552 \\
\hline Illinois & 7.14 \\
\hline Indiana & 38.5 \\
\hline Kansas & 384 \\
\hline Kentucky & 102 \\
\hline Louisiana & 2.93 \\
\hline Missouri & 54.4 \\
\hline Montana & 7.24 \\
\hline Nebraska & 2.61 \\
\hline New York & 4.07 \\
\hline Ohio & 100 \\
\hline Oklahoma & 126 \\
\hline Pennsylvania & 70.2 \\
\hline South Dakota & 13.6 \\
\hline Tennessee & 2.30 \\
\hline Texas & 12.6 \\
\hline Utah & 24.8 \\
\hline West Virginia & 21.3 \\
\hline Wyoming & 9.59 \\
\hline Total & $\mathbf{1 6 0}$ \\
\hline & \\
\hline
\end{tabular}

attributed to stream-valley aquifers associated with the South Platte (404 Mgal/d) and Arkansas (134 Mgal/d) Rivers, and miscellaneous rivers in mountainous areas (14.6 Mgal/d) (fig. 5, table 3). The withdrawals were used mostly for irrigation (526 Mgal/d). The revised total Alluvial aquifers withdrawals (17.8 Mgal/d, table 1) were attributed to eolian sands and isolated terrace deposits, and were used mostly for irrigation (15.2 Mgal/d, table 3).

The reassignment reduced withdrawals from Other aquifers by about 65 percent to $40.5 \mathrm{Mgal} / \mathrm{d}$ (table 1). The withdrawals were attributed to seven bedrock aquifers and were used mostly for irrigation (30.1 Mgal/d, table 4).

\section{Illinois}

In 2000, total ground-water withdrawals for all categories of use in Illinois were about $813 \mathrm{Mgal} / \mathrm{d}$ (Hutson and others, 2004). About 78 percent (634 Mgal/d) of the withdrawals were for public-supply, self-supplied industrial, and irrigation uses, and were assigned to five principal aquifers, including glacial sand and gravel aquifers and Other aquifers (Maupin and Barber, 2005) (appendix 2). Withdrawals from glacial sand and gravel aquifers (413 Mgal/d) accounted for 65 percent of total withdrawals from principal and Other aquifers, and included $181 \mathrm{Mgal} / \mathrm{d}$ for public-supply, $140 \mathrm{Mgal} / \mathrm{d}$ for irrigation, and 91.9 Mgal/d for self-supplied industrial uses (appendix 2). No withdrawals were assigned to the Mississippi River Valley alluvial aquifer (fig. 6) or Alluvial aquifers in Illinois in 2000 (Maupin and Barber, 2005). Total withdrawals from Other aquifers were $10.9 \mathrm{Mgal} / \mathrm{d}$ (appendix 2). No withdrawals from Other aquifers could be attributed to stream-valley aquifers.

Withdrawals of $7.14 \mathrm{Mgal} / \mathrm{d}$ for irrigation and publicsupply uses in Illinois were reassigned from glacial sand and gravel aquifers to stream-valley aquifers (table 3 ). The withdrawals were 5.52, 1.19, and $0.43 \mathrm{Mgal} / \mathrm{d}$ from stream-valley aquifers associated with the Ohio River, the Mississippi River below St. Louis, and the Wabash River, respectively (fig. 6, table 3).

Withdrawals of $2.44 \mathrm{Mgal} / \mathrm{d}$ were reassigned from glacial sand and gravel aquifers to the Mississippi River Valley alluvial aquifer (fig. 6, table 1). The withdrawals included 1.63 Mgal/d for irrigation and $0.81 \mathrm{Mgal} / \mathrm{d}$ for public-supply uses (table 3). The reassignments of withdrawals reduced total withdrawals from glacial sand and gravel aquifers in Illinois by $9.58 \mathrm{Mgal} / \mathrm{d}$, about 2 percent (table 1 ).

\section{Indiana}

In 2000, total ground-water withdrawals for all categories of use in Indiana were $656 \mathrm{Mgal} / \mathrm{d}$ (Hutson and others, 2004). About 76 percent (500 Mgal/d) of the withdrawals were for public-supply, self-supplied industrial, and irrigation uses, and were assigned to four principal and Other aquifers (Maupin and Barber, 2005) (appendix 2). No withdrawals were assigned to Alluvial aquifers in Indiana in 2000. Withdrawals from glacial sand and gravel aquifers (455 Mgal/d) accounted for 91 percent of total withdrawals from principal and Other aquifers, and included $309 \mathrm{Mgal} / \mathrm{d}$ for public-supply, 94.9 Mgal/d for self-supplied industrial, and 50.6 Mgal/d for irrigation uses. Total withdrawals from Other aquifers were $0.10 \mathrm{Mgal} / \mathrm{d}$. No withdrawals from Other aquifers were attributed to stream-valley aquifers.

Withdrawals of $38.5 \mathrm{Mgal} / \mathrm{d}$ were reassigned from glacial sand and gravel aquifers to stream-valley aquifers in Indiana (table 1). The withdrawals were 37.0, 1.19, and $0.37 \mathrm{Mgal} / \mathrm{d}$ from stream-valley aquifers associated with the Ohio River, the Lower East Fork White River, and the Wabash River, respectively (fig. 7, table 3). The withdrawals included 33.0 Mgal/d for public-supply, $4.98 \mathrm{Mgal} / \mathrm{d}$ for self-supplied industrial, and $0.51 \mathrm{Mgal} / \mathrm{d}$ for irrigation uses. The reassignment of withdrawals reduced withdrawals from glacial sand and gravel aquifers in Indiana by about 8 percent, to $416 \mathrm{Mgal} / \mathrm{d}$ (table 1). 
Table 3. Estimated withdrawals for irrigation, public-supply, and self-supplied industrial uses from stream-valley aquifers associated with major rivers and principal aquifers in 20 States, 2000.

[Values have been rounded]

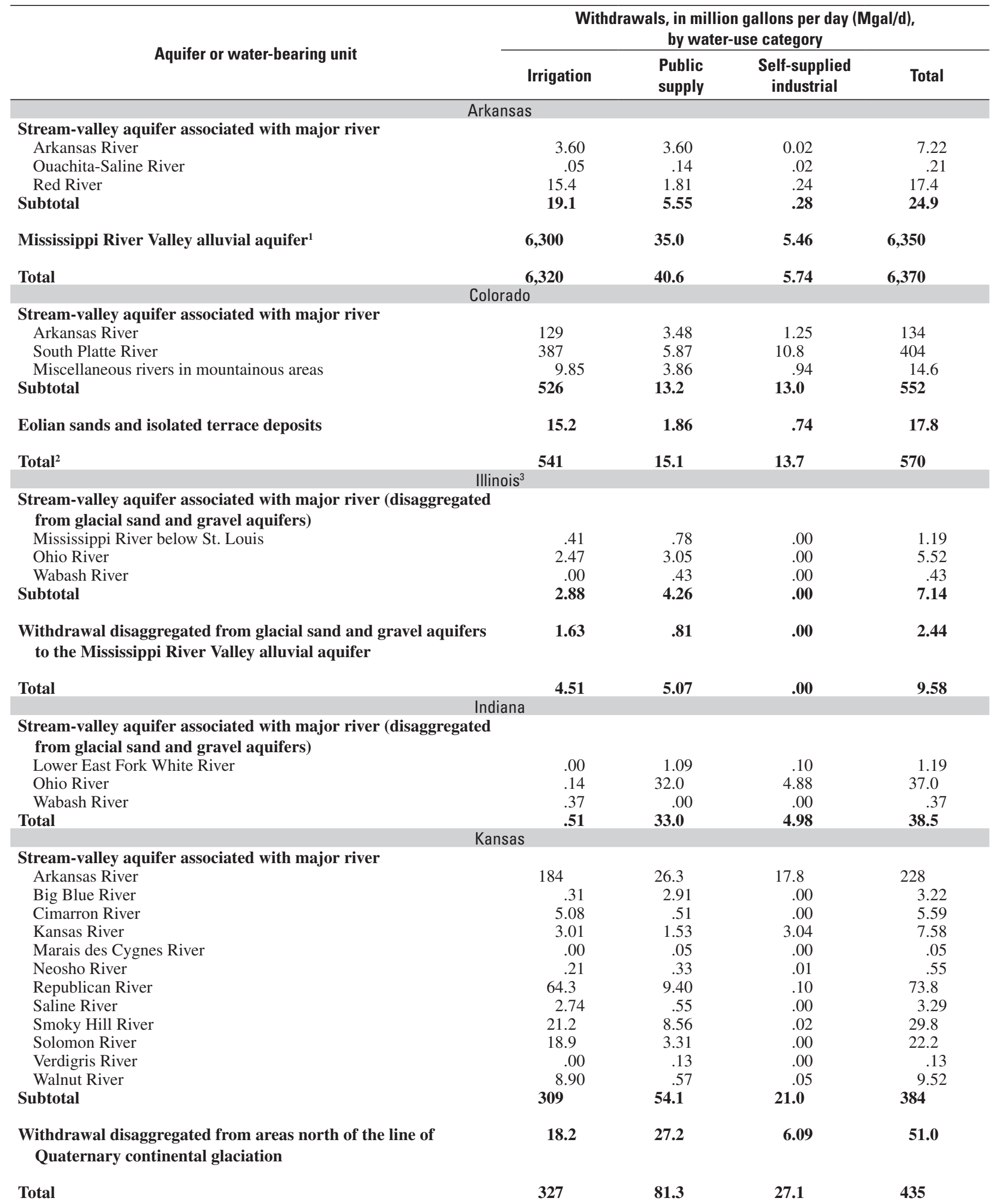


Table 3. Estimated withdrawals for irrigation, public-supply, and self-supplied industrial uses from stream-valley aquifers associated with major rivers and principal aquifers in 20 States, 2000-Continued.

[Values have been rounded]

\begin{tabular}{|c|c|c|c|c|}
\hline \multirow{2}{*}{ Aquifer or water-bearing unit } & \multicolumn{4}{|c|}{$\begin{array}{l}\text { Withdrawals, in million gallons per day (Mgal/d), } \\
\text { by water-use category }\end{array}$} \\
\hline & Irrigation & $\begin{array}{l}\text { Public } \\
\text { supply }\end{array}$ & $\begin{array}{l}\text { Self-supplied } \\
\text { industrial }\end{array}$ & Total \\
\hline \multicolumn{5}{|l|}{$\begin{array}{l}\text { Stream-valley aquifer associated with major river (disaggregated } \\
\text { from Alluvial aquifers) }\end{array}$} \\
\hline Ohio River & 0.00 & 40.8 & 60.9 & 102 \\
\hline Total & .00 & 47.2 & 76.1 & 123 \\
\hline \multicolumn{5}{|c|}{ Louisiana } \\
\hline \multicolumn{5}{|l|}{ Stream-valley aquifer associated with major river } \\
\hline \multicolumn{5}{|l|}{ Alluvial aquifers withdrawals reassigned to a principal aquifer } \\
\hline Subtotal & 3.85 & .00 & .00 & 3.85 \\
\hline Total & 6.62 & .16 & .00 & 6.78 \\
\hline \multicolumn{5}{|c|}{ Missouri } \\
\hline \multicolumn{5}{|l|}{ Stream-valley aquifer associated with major river } \\
\hline Mississippi River below St. Louis & .00 & 3.24 & .29 & 3.53 \\
\hline Missouri River & 1.23 & 46.6 & 2.27 & 50.1 \\
\hline South Grand River & .21 & .19 & .00 & .40 \\
\hline Osage River & .33 & .07 & .00 & .40 \\
\hline Subtotal & 1.77 & 50.1 & 2.56 & 54.4 \\
\hline $\begin{array}{l}\text { Withdrawal disaggregated from areas north of the line of Qua- } \\
\text { ternary continental glaciation }\end{array}$ & 57.2 & 55.8 & 8.52 & 122 \\
\hline Alluvial aquifers, withdrawal not disaggregated & 16.2 & 9.48 & .67 & 26.3 \\
\hline Total & 21.7 & 11.1 & .77 & 33.6 \\
\hline \multicolumn{5}{|c|}{ Nebraska } \\
\hline \multicolumn{5}{|l|}{ Stream-valley aquifer associated with major river } \\
\hline Big Blue River & .00 & .00 & 1.67 & 1.67 \\
\hline Missouri River & .07 & .80 & .07 & .94 \\
\hline Subtotal & .07 & .80 & 1.74 & 2.61 \\
\hline Alluvial aquifers, withdrawal not disaggregated & 92.1 & 49.2 & 5.94 & 147 \\
\hline Total & 92.2 & 50.0 & 7.68 & 150 \\
\hline \multicolumn{5}{|c|}{ New York } \\
\hline Stream-valley aquifer associated with the following river & & & & \\
\hline Allegheny River & .00 & 4.07 & .00 & 4.07 \\
\hline Withdrawal from Cattarougus County not disaggregated & .00 & 3.37 & 2.68 & 6.05 \\
\hline Total & .00 & 7.44 & 2.68 & 10.1 \\
\hline
\end{tabular}


Table 3. Estimated withdrawals for irrigation, public-supply, and self-supplied industrial uses from stream-valley aquifers associated with major rivers and principal aquifers in 20 States, 2000-Continued.

[Values have been rounded]

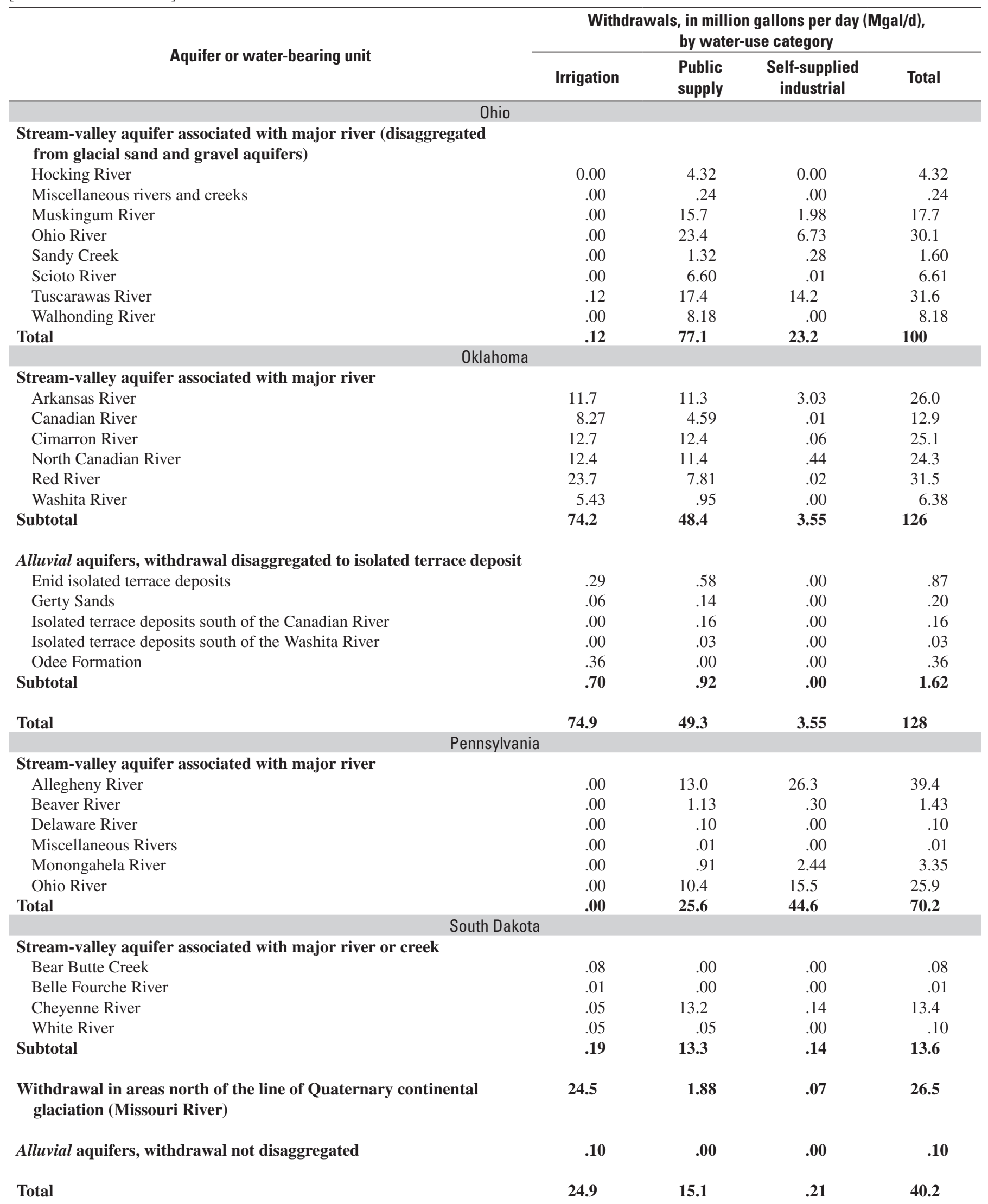


Table 3. Estimated withdrawals for irrigation, public-supply, and self-supplied industrial uses from stream-valley aquifers associated with major rivers and principal aquifers in 20 States, 2000-Continued.

[Values have been rounded]

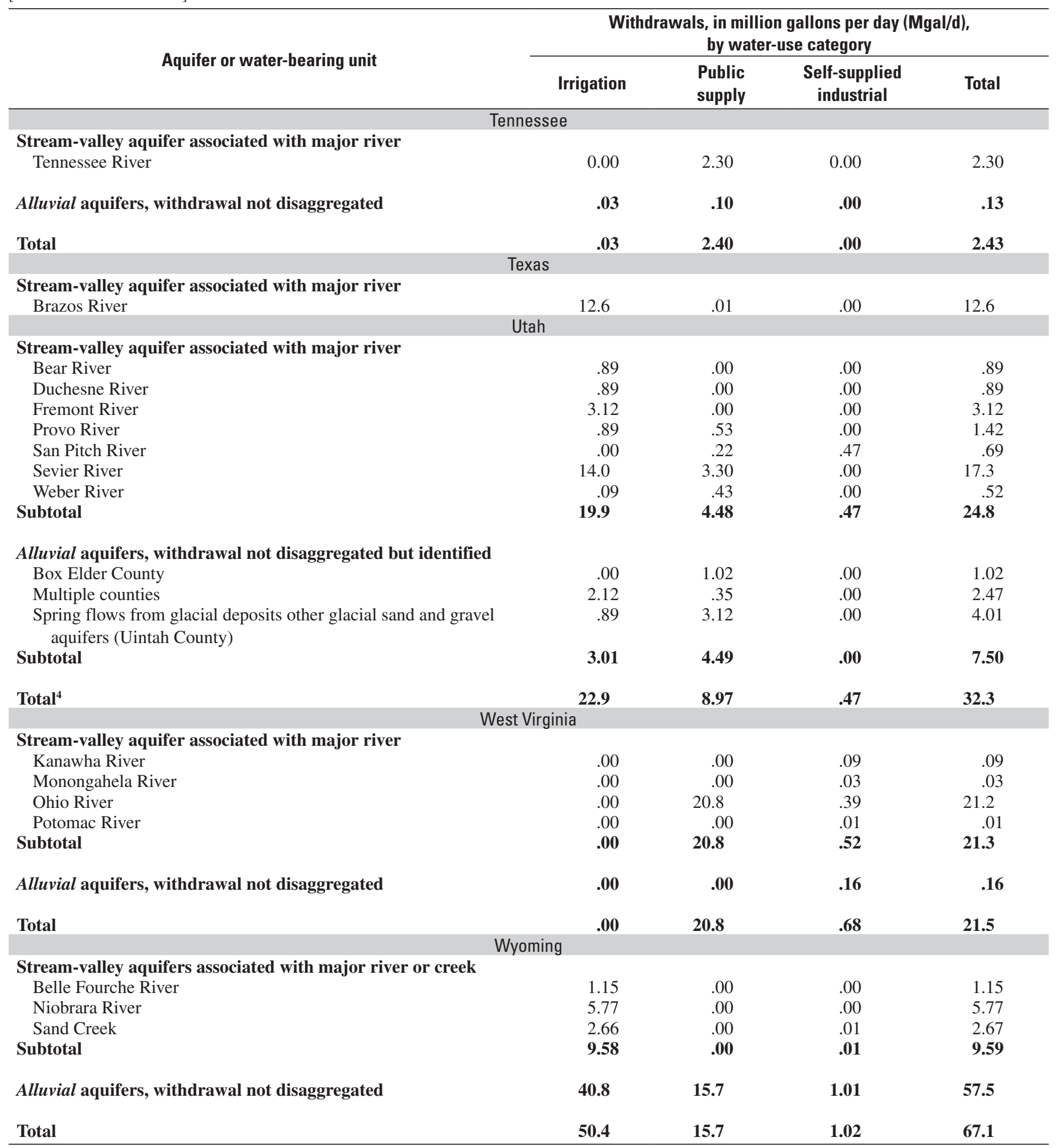

${ }^{1}$ Total withdrawals from Mississippi River Valley alluvial aquifer do not equal total in appendix 1 because about $25 \mathrm{Mgal} / \mathrm{d}$ were identified to be from streamvalley aquifers associated with the listed rivers.

${ }^{2}$ Total withdrawals are greater than total Alluvial aquifers withdrawals in appendix 2 because withdrawals from Other aquifers are assigned to stream-valley aquifers associated with rivers or eolian sand and isolated terrace deposits.

${ }^{3}$ Illinois State Water Survey's Public-Industrial-Commercial Database was a source of water-use data.

${ }^{4}$ Total public-supply withdrawals in this table are greater than total public-supply withdrawals from Alluvial aquifers (appendix 2) because $0.77 \mathrm{Mgal} / \mathrm{d}$ from Basin and Range basin-fill aquifers were assigned to Alluvial aquifers. Total withdrawals also are greater. 
Table 4. Distribution of estimated withdrawals for irrigation, public-supply, and self-supplied industrial uses from aquifers and waterbearing units disaggregated from withdrawals from Other aquifers in 10 States, 2000.

[Values have been rounded. Names and descriptions of aquifers and geologic units listed in this table are those used by various U.S. Geological Survey offices or supplied by other agencies for water-use accounting purposes and do not necessarily correspond to officially recognized names or denote any official acceptances of these names and descriptions. However, the names and descriptions are included here to provide more detailed information of aquifers and aquifer units disaggregated from $O$ ther]

\begin{tabular}{|c|c|c|c|c|c|}
\hline \multirow{2}{*}{ State } & \multirow{2}{*}{ Aquifer or water-bearing unit } & \multicolumn{4}{|c|}{$\begin{array}{c}\text { Withdrawals, in million gallons per day, } \\
\text { by water-use category }\end{array}$} \\
\hline & & Irrigation & $\begin{array}{l}\text { Public } \\
\text { supply }\end{array}$ & $\begin{array}{c}\text { Self-supplied } \\
\text { industrial }\end{array}$ & Total \\
\hline \multirow{6}{*}{ Colorado $^{1}$} & Dakota-Cheyenne aquifer & 11.4 & 1.93 & .20 & 13.5 \\
\hline & Fractured crystalline-rock aquifers & 4.08 & 4.92 & .47 & 9.50 \\
\hline & Leadville Limestone group & 1.30 & .78 & .20 & 2.30 \\
\hline & North, Middle, and South Park Basins & .57 & .33 & .08 & 1.00 \\
\hline & Raton Basin & 1.92 & .55 & .39 & 2.90 \\
\hline & Total & 30.1 & 8.90 & 1.50 & 40.5 \\
\hline \multirow{15}{*}{ Kansas } & Carlile Shale & .00 & .02 & .01 & .03 \\
\hline & Chase Group & .04 & .12 & .00 & .16 \\
\hline & Cheyenne-Jurassic-Triassic & .78 & .00 & .00 & .78 \\
\hline & Colorado Group & .44 & .00 & .00 & .44 \\
\hline & Council Grove Group & .00 & .03 & .00 & .03 \\
\hline & Cretaceous System & .00 & .06 & .00 & .06 \\
\hline & Douglas Group & .00 & .01 & .00 & .01 \\
\hline & Glacial Deposits (State defined) & 12.3 & .49 & .00 & 12.8 \\
\hline & Kansas Stage & .21 & .29 & .00 & .50 \\
\hline & Meade Formation & .00 & .54 & .00 & .54 \\
\hline & Stranger Formation & .00 & .18 & .00 & .18 \\
\hline & Sumner Group & .11 & .00 & .00 & .11 \\
\hline & Unknown & 65.7 & 2.87 & .38 & 69.0 \\
\hline & Wellington Formation & .13 & .00 & .07 & .20 \\
\hline & Total & 83.5 & 5.10 & .48 & 89.0 \\
\hline Nebraska & Pliocene-Pleistocene aquifers & 4.12 & 10.3 & 1.08 & 15.5 \\
\hline North Dakota & $\begin{array}{l}\text { Variously named aquifers, some in counties coincident with } \\
\text { glaciated regions }\end{array}$ & 2.34 & 4.28 & .44 & 7.06 \\
\hline Ohio & Cambrain-Ordovician and unknown aquifers & .06 & 4.35 & 1.40 & 5.81 \\
\hline \multirow[t]{6}{*}{ Oklahoma } & Atoka Formation & .00 & .26 & .00 & .26 \\
\hline & Bison Shale & .00 & .13 & .00 & .13 \\
\hline & Boggy Formation & .04 & .35 & .00 & .39 \\
\hline & Cambrian System & .00 & .05 & .00 & .05 \\
\hline & Cedar Hills Sandstone & .23 & .98 & .00 & 1.21 \\
\hline & Chickasha Formation & .01 & .18 & .00 & .19 \\
\hline
\end{tabular}


Table 4. Distribution of estimated withdrawals for irrigation, public-supply, and self-supplied industrial uses from aquifers and waterbearing units disaggregated from withdrawals from Other aquifers in 10 States, 2000—Continued.

[Values have been rounded. Names and descriptions of aquifers and geologic units listed in this table are those used by various U.S. Geological Survey offices or supplied by other agencies for water-use accounting purposes and do not necessarily correspond to officially recognized names or denote any official acceptances of these names and descriptions. However, the names and descriptions are included here to provide more detailed information of aquifers and aquifer units disaggregated from $O t h e r$ ]

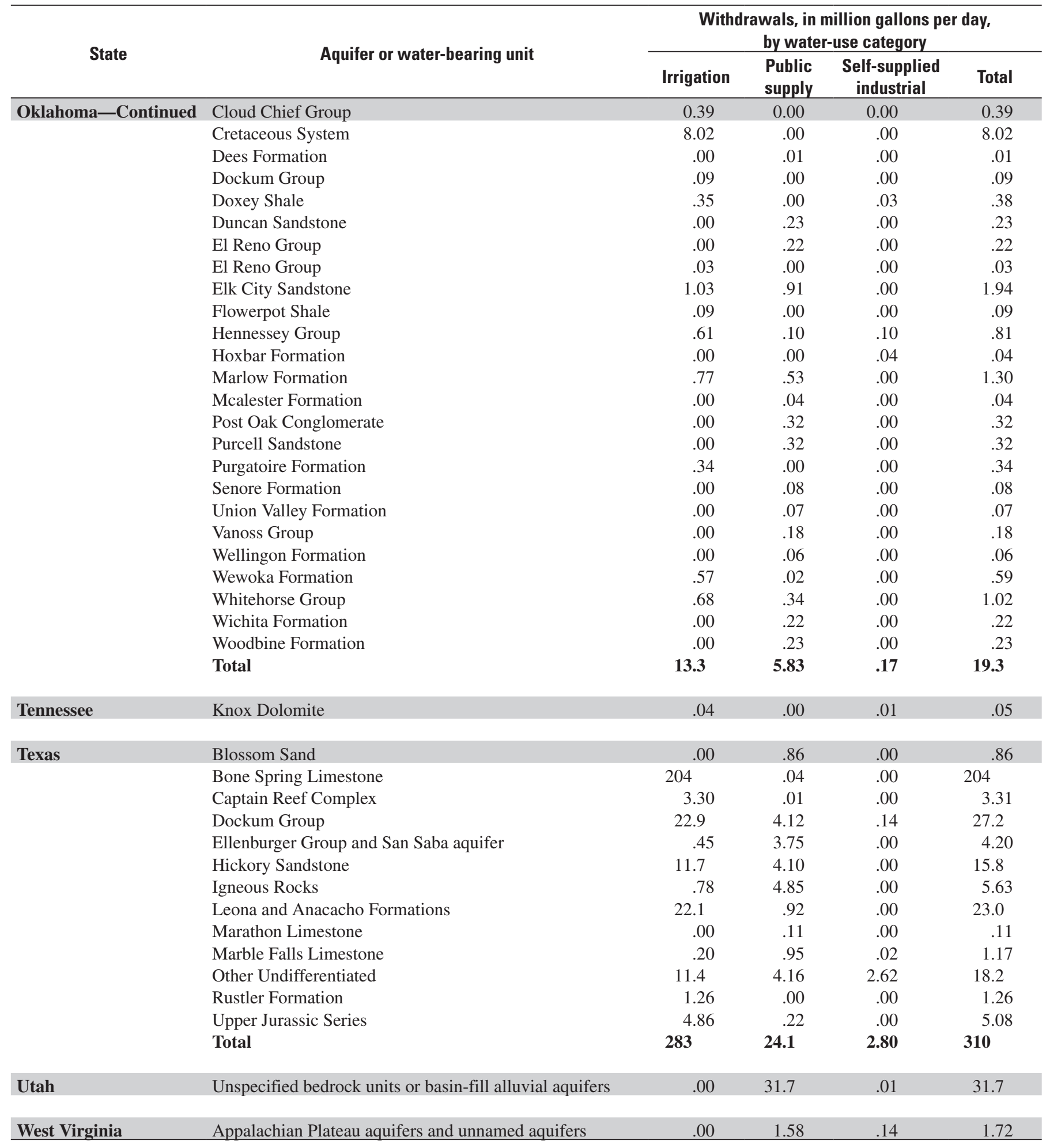

${ }^{1}$ Total withdrawals from Other aquifers in Colorado do not equal Other aquifers in appendix 1 because some withdrawals were assigned to stream-valley aquifers (see tables 1 and 3). 


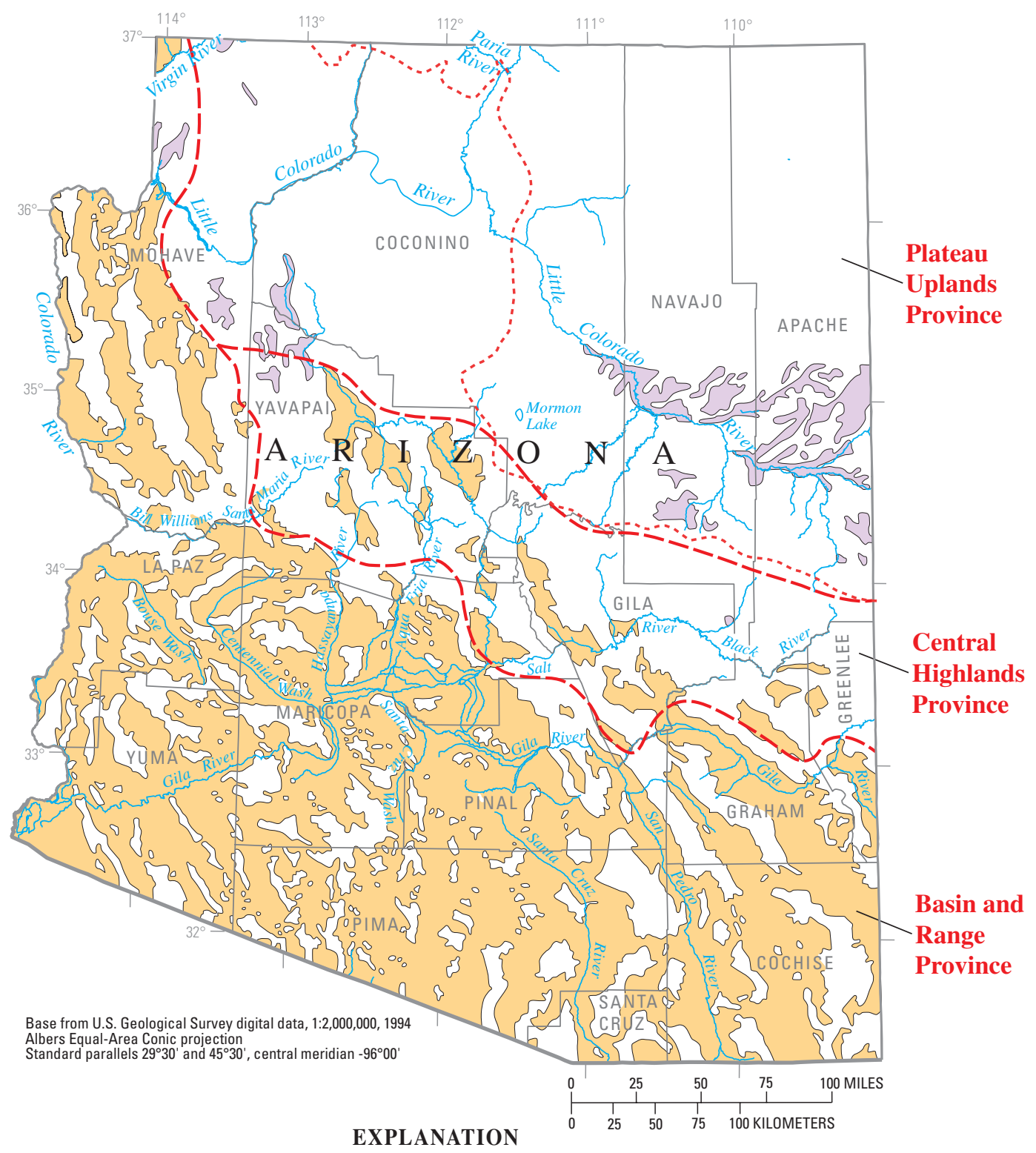

Extent of alluvial or eolian deposits

Mountainous area

Basin and range area

- - Boundary of geographic province

- . - - Approximate southwestern extent of Colorado Plateaus aquifers

Figure 3. Extent of alluvial deposits in Arizona where stream-valley aquifer withdrawals were investigated (source: Miller, 2000, fig. 18, p. C7).

\section{Kansas}

In 2000, total ground-water withdrawals for all categories of use in Kansas were 3,790 Mgal/d (Hutson and others, 2004). More than 96 percent $(3,650 \mathrm{Mgal} / \mathrm{d})$ of the withdrawals were for public-supply, self-supplied industrial, and irrigation uses, and were assigned to five principal and
Other aquifers (Maupin and Barber, 2005) (appendix 2). Withdrawals from Alluvial (435 Mgal/d) and Other (89.0 Mgal/d) aquifers accounted for 14 percent of the withdrawals from principal aquifers and Other aquifers (appendix 2). Withdrawals were used mostly for irrigation from Alluvial (327 Mgal/d) and Other (83.5 Mgal/d) aquifers. 


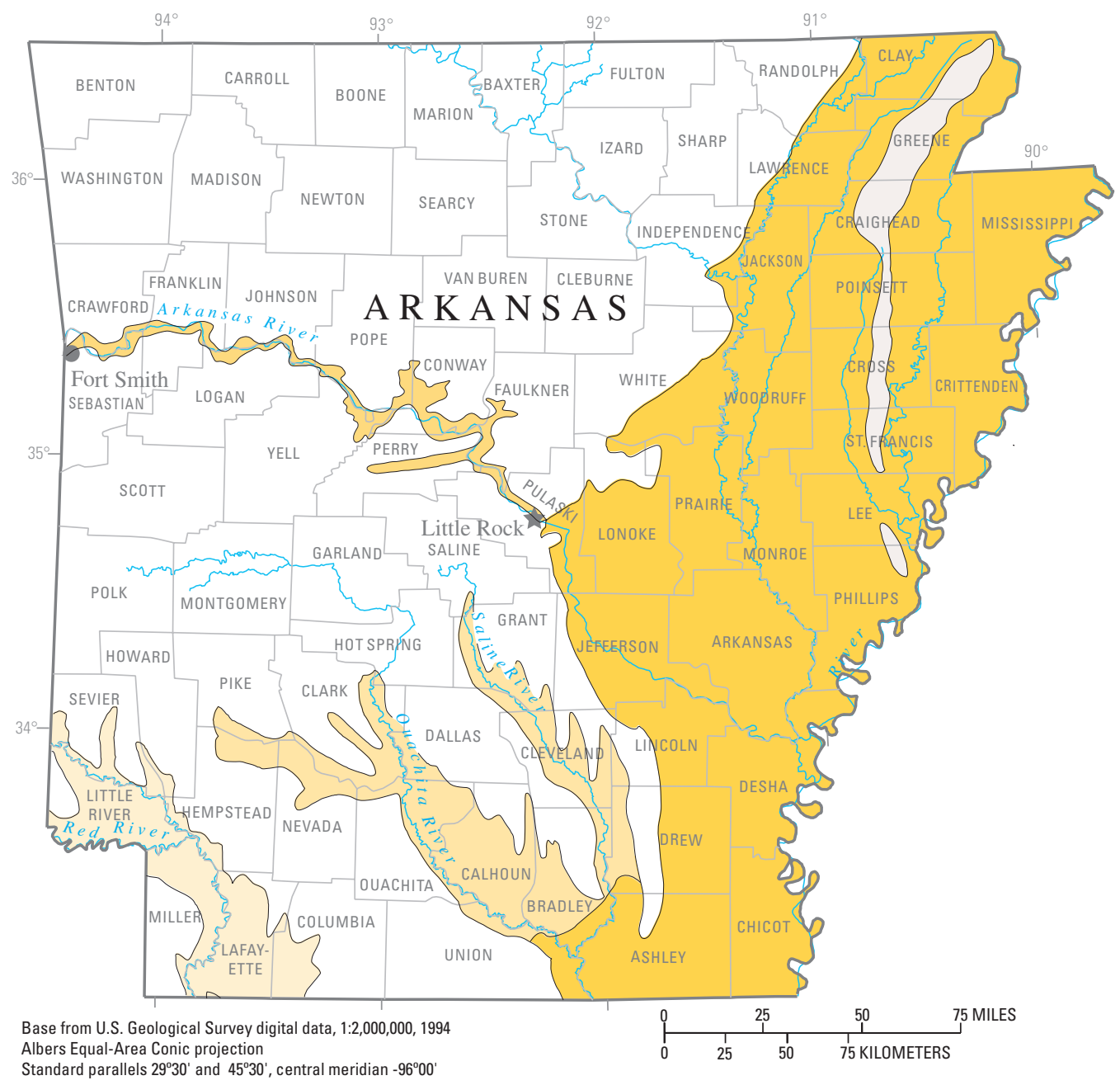

EXPLANATION

Surficial aquifer system

Mississippi River Valley alluvial aquifer

Arkansas River alluvial aquifer

Ouachita-Saline Rivers alluvial aquifer

Red River alluvial aquifer

Figure 4. Extent of the Mississippi River Valley alluvial aquifer and other surficial alluvial aquifers along major rivers in Arkansas where withdrawals were associated with stream-valley aquifers (source: Miller, 2000, fig. 23, p. F8). Withdrawals from stream-valley aquifers were identified from a subset of the alluvial deposits along the Red, Arkansas, and Ouachita-Saline Rivers. These withdrawals had been attributed to the Mississippi River Valley alluvial aquifer.

Withdrawals of $384 \mathrm{Mgal} / \mathrm{d}$ from Alluvial aquifers in Kansas were attributed to stream-valley aquifers associated with 12 major rivers (table 3). Withdrawals from a streamvalley aquifer associated with the Arkansas River (228 Mgal/d, fig. 8) accounted for more than half of the total stream-valley aquifer withdrawals. About 80 percent of withdrawals from stream-valley aquifers in Kansas were used for irrigation (309 Mgal/d). The revised total Alluvial aquifers withdrawals
(51.0 Mgal/d, table 1) were attributed to withdrawals disaggregated from areas north of the line of Quaternary continental glaciation, and were used mostly for public supply (27.2 Mgal/d, table 3).

Withdrawals from Other aquifers could not be attributed to stream-valley aquifers. The withdrawals were attributed to (1) various bedrock units, (2) deposits that are locally recognized as glacial deposits, but are located south of the 


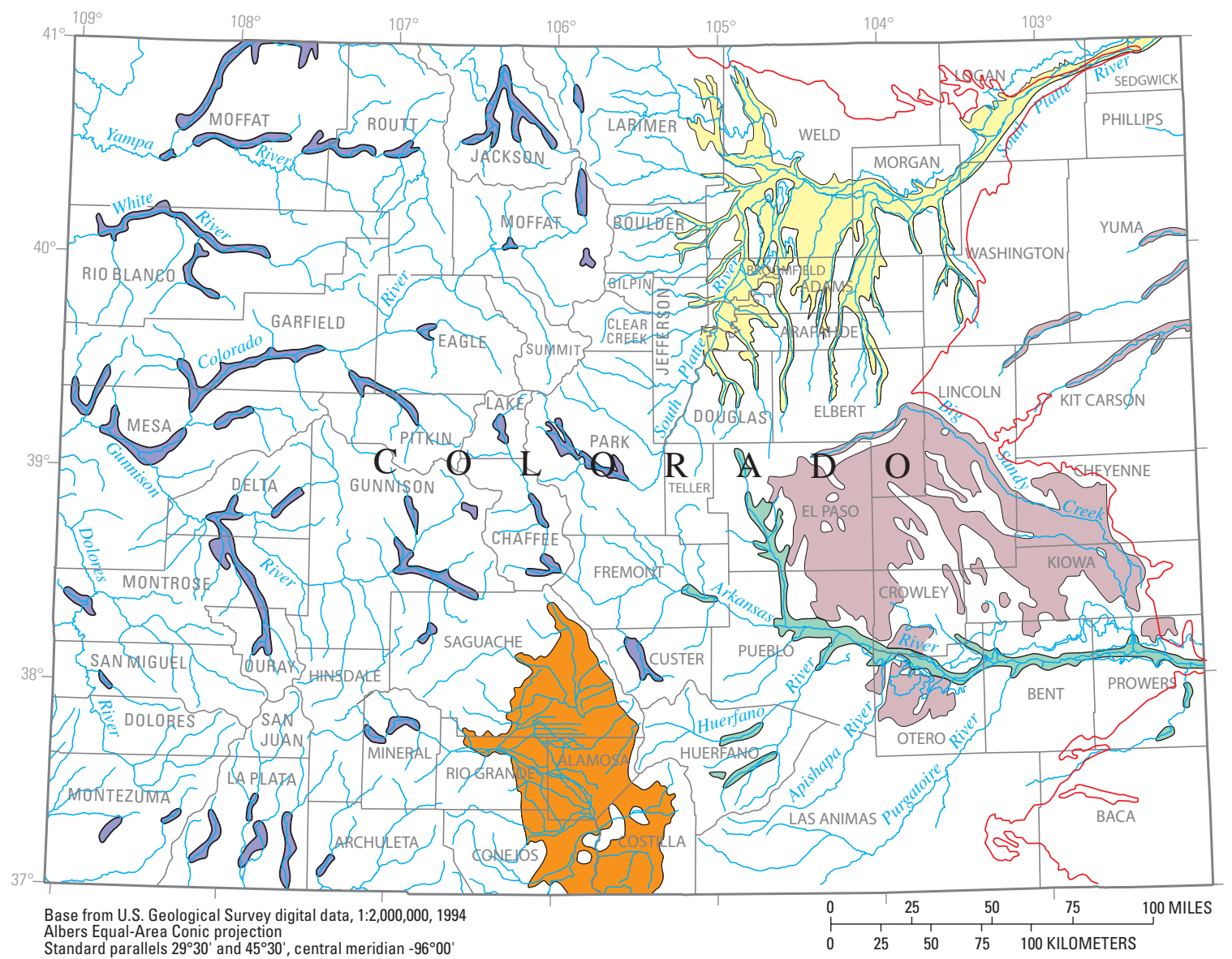

EXPLANATION

Extent of alluvial or eolian deposits

Mountainous area

South Platte River Valley area

Arkansas River Valley area

Upland plains area

Rio Grande basin area

Extent of High Plains aquifer in Colorado

Figure 5. Extent of alluvial deposits in Colorado where withdrawals from Alluvial and Other aquifers were associated with streamvalley aquifers (source: Miller, 2000, fig. 18, p. C7). Withdrawals from stream-valley aquifers were identified from a subset of the alluvial deposits. (See fig. 1 for full extent of the High Plains aquifer.)

extent of Quaternary continental glaciation (fig. 8), and (3) unknown (table 4). No withdrawals from Other aquifers were attributed to stream-valley aquifers.

\section{Kentucky}

In 2000, total ground-water withdrawals for all categories of use in Kentucky were about $189 \mathrm{Mgal} / \mathrm{d}$ (Hutson and others, 2004). About 88 percent (167 Mgal/d) were for public-supply, self-supplied industrial, and irrigation uses, and were assigned to five principal and Other aquifers (Maupin and Barber, 2005) (appendix 2). Withdrawals from Alluvial aquifers totaled $123 \mathrm{Mgal} / \mathrm{d}$, mostly for self-supplied industrial (76.1 Mgal/d) and public-supply (47.1 Mgal/d) uses. Withdrawals from Other aquifers were $1.24 \mathrm{Mgal} / \mathrm{d}$ and used for irrigation (appendix 2). 


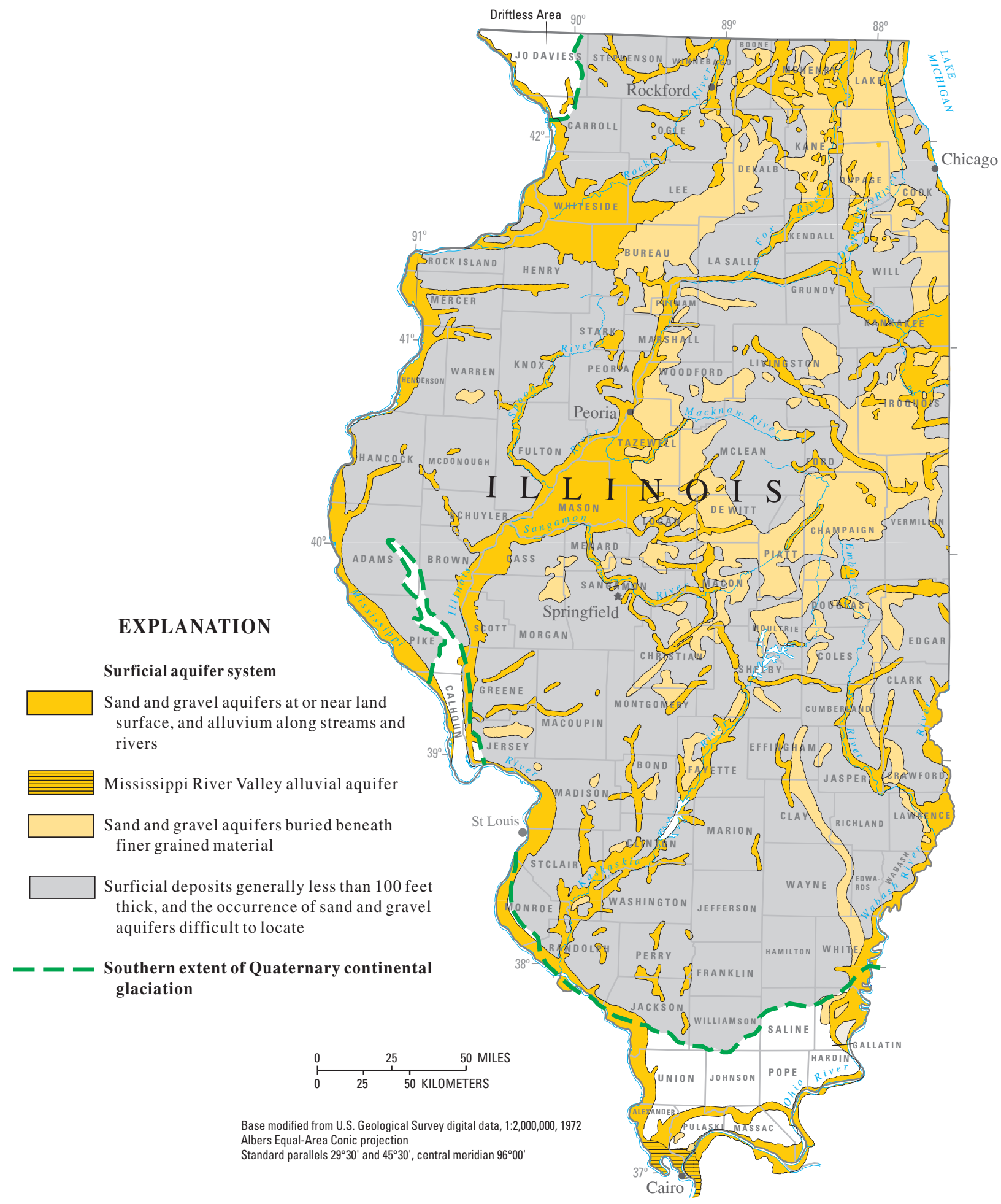

Figure 6. Extent of alluvial deposits and the Mississippi River Valley alluvial aquifer in Illinois that were evaluated for possible withdrawals from stream-valley aquifers (source: Miller, 2000, fig. 4, p. K3). Some of the withdrawals from glacial sand and gravel aquifers were attributed to stream-valley aquifers in a subset of the sediments in the non-glaciated area. 


\section{EXPLANATION}

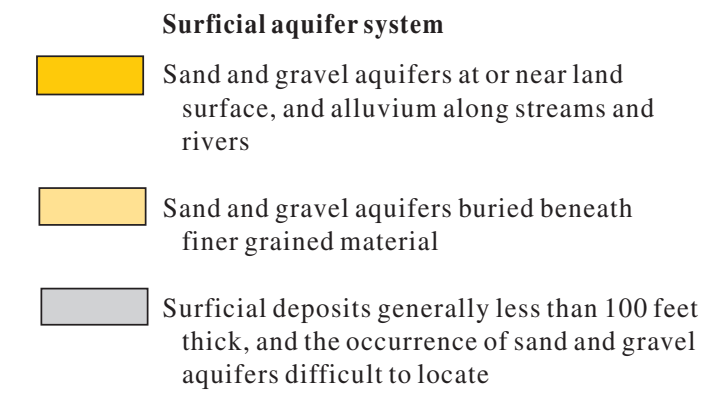

- Southern extent of Quaternary continental glaciation

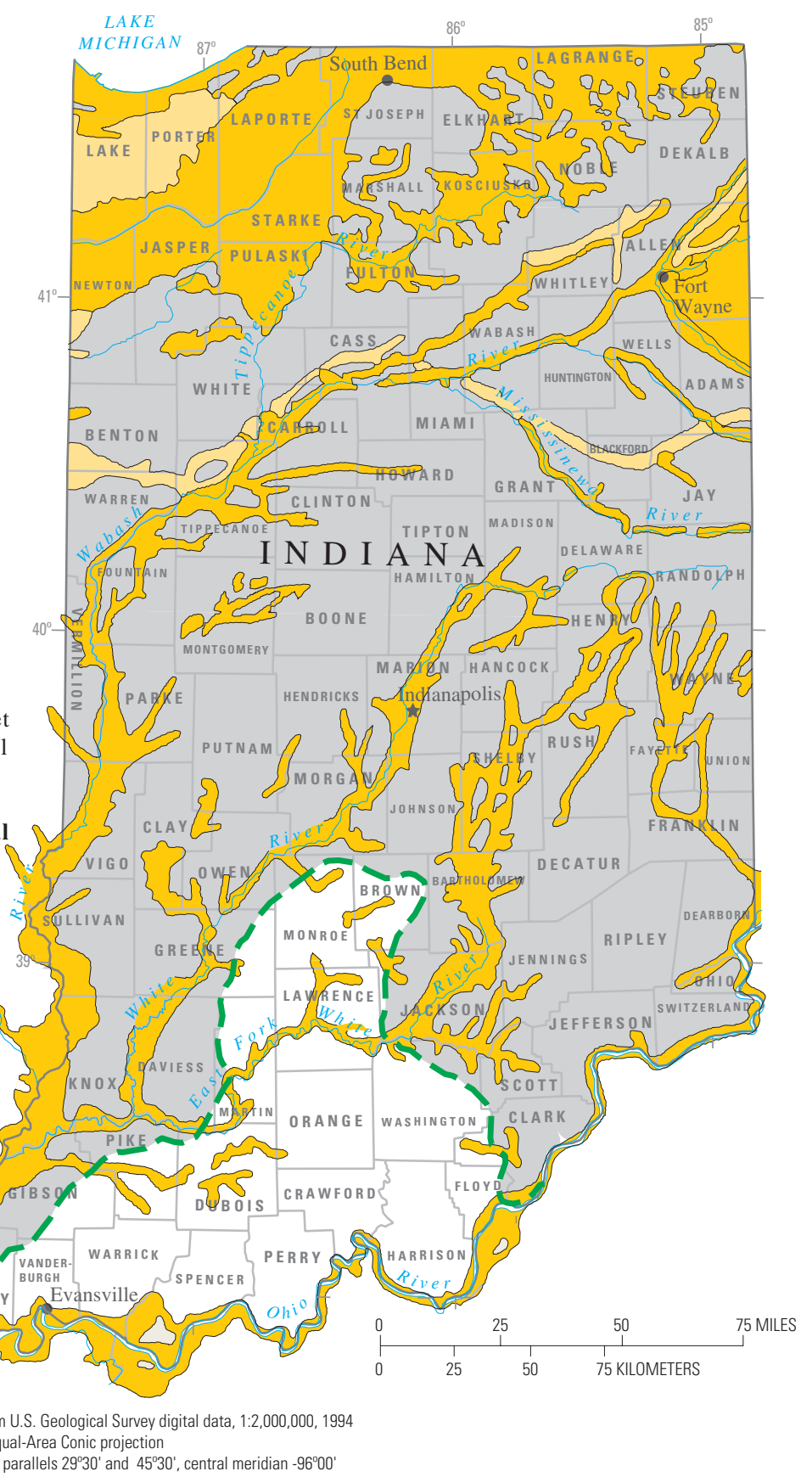

Figure 7. Extent of alluvial deposits in Indiana that were evaluated for possible withdrawals from stream-valley aquifers (source: Miller, 2000, fig. 4, p. K3). Some of the withdrawals from glacial sand and gravel aquifers were attributed to stream-valley aquifers in a subset of the sediments in the non-glaciated area.

Alluvial aquifers withdrawals of $102 \mathrm{Mgal} / \mathrm{d}$ in counties south of the extent of Quaternary continental glaciation were assigned to stream-valley aquifers associated with the Ohio River (fig. 9, table 3). The withdrawals were for selfsupplied industrial uses (60.9 Mgal/d) and public-supply uses (40.8 Mgal/d). The revised total Alluvial aquifers with- drawals (21.6 Mgal/d, table 1) were attributed to Alluvial aquifer withdrawals that may be from areas north of the southern extent of Quaternary continental glaciation, and were used mostly for self-supplied industrial use (15.2 Mgal/d, table 3). Withdrawals from Other aquifers could not be attributed to stream-valley aquifers in Kentucky. 


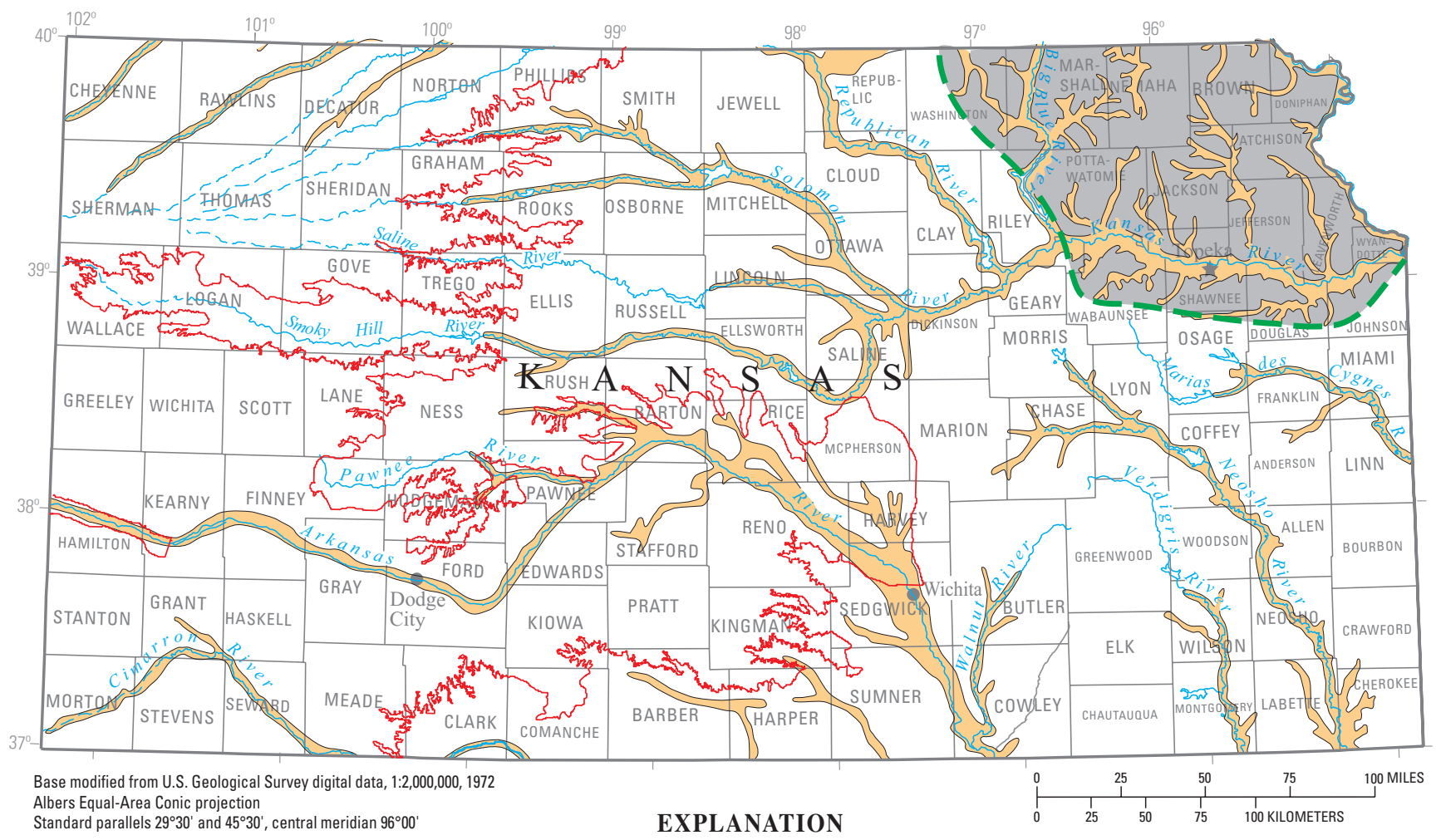

Coarse-grained glacial deposits, and streamvalley alluvium

Till, loess, and fine-grained glacial-lake deposits

- Southern extent of Quaternary continental glaciation

Extent of High Plains aquifer in Kansas

Figure 8. Extent of alluvial deposits in Kansas where withdrawals from Alluvial aquifers were associated with stream-valley aquifers (source: Miller, 2000, fig. 4, p. D3). Withdrawals from stream-valley aquifers were identified from a subset of the alluvial deposits east of the High Plains aquifer and outside the glaciated region. (See fig. 1 for full extent of the High Plains aquifer.)

\section{Louisiana}

In 2000, total ground-water withdrawals for all categories of use in Louisiana were about 1,630 Mgal/d (Hutson and others, 2004). About 88 percent (1,430 Mgal/d) of the withdrawals were for public-supply, self-supplied industrial, and irrigation uses, and were assigned to four principal aquifers, including Alluvial aquifers, the Coastal lowlands aquifer system, the Mississippi embayment aquifer system, and the Mississippi River Valley alluvial aquifer (Maupin and Barber, 2005) (fig. 10, appendix 2). No withdrawals were from Other aquifers in Louisiana in 2000 (Maupin and Barber, 2005). Withdrawals from the Coastal lowlands aquifer system accounted for about 73 percent of the water withdrawals from principal aquifers in Louisiana.

Withdrawals of $2.93 \mathrm{Mgal} / \mathrm{d}$ from Alluvial aquifers were attributed to a stream-valley aquifer associated with the Red River (fig. 10, table 3). The withdrawals were for irrigation (2.77 Mgal/d) and public-supply (0.16 Mgal/d). Additional withdrawals of $3.85 \mathrm{Mgal} / \mathrm{d}$ from Alluvial aquifers were reas- signed to the Coastal lowlands aquifer system (2.35 Mgal/d) and the Mississippi River Valley alluvial aquifer $(1.51 \mathrm{Mgal} / \mathrm{d})$ (fig. 10, table 1). All the reassigned withdrawals were for irrigation (table 3 ).

\section{Missouri}

In 2000, total ground-water withdrawals for all categories of use in Missouri were 1,780 Mgal/d (Hutson and others, 2004). About 95 percent $(1,690 \mathrm{Mgal} / \mathrm{d})$ of the withdrawals were for public-supply, self-supplied industrial, and irrigation uses, and were assigned to six principal aquifers (Maupin and Barber, 2005) (appendix 2). Withdrawals from Alluvial aquifers were $176 \mathrm{Mgal} / \mathrm{d}$, accounting for 10 percent of withdrawals from principal aquifers. Withdrawals from Alluvial aquifers were for public-supply (106 Mgal/d), irrigation (59.0 Mgal/d), and self-supplied industrial (11.1 Mgal/d) uses (appendix 2). No withdrawals were from Other aquifers in Missouri in 2000 (Maupin and Barber, 2005). 


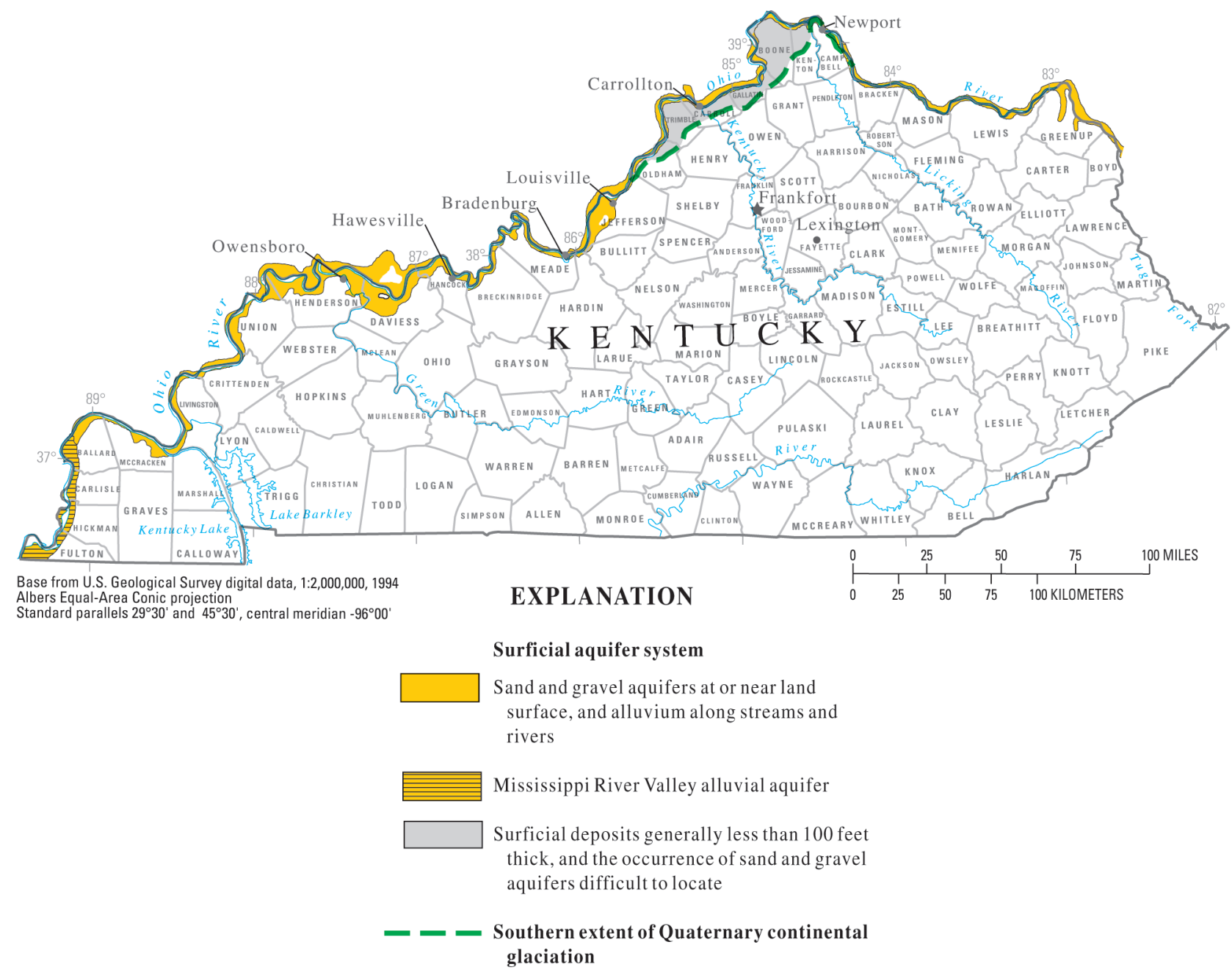

Figure 9. Extent of alluvial deposits in Kentucky where withdrawals from Alluvial aquifers were associated with stream-valley aquifers (source: Miller, 2000, fig. 4, p. K3). Withdrawals from stream-valley aquifers were identified from a subset of the alluvial deposits along the Ohio River.

Withdrawals of $54.4 \mathrm{Mgal} / \mathrm{d}$ from Alluvial aquifers were attributed to stream-valley aquifers associated with the Missouri (50.1 Mgal/d), Mississippi (3.53 Mgal/d), Osage $(0.40 \mathrm{Mgal} / \mathrm{d})$, and South Grand $(0.40 \mathrm{Mgal} / \mathrm{d})$ Rivers (fig. 11, table 3). About 92 percent (50.1 Mgal/d) of the withdrawals were for public-supply. The revised total Alluvial aquifers withdrawals (122 Mgal/d, table 1) were attributed to withdrawals disaggregated from areas north of the line of Quaternary continental glaciation, and were used mostly for irrigation (57.2 Mgal/d) and public supply (55.8 Mgal/d, table 3).

\section{Montana}

In 2000, total ground-water withdrawals for all categories of use in Montana were $188 \mathrm{Mgal} / \mathrm{d}$ (Hutson and others, 2004). About 91 percent (171 Mgal/d) of the withdrawals were for public-supply, self-supplied industrial, and irrigation uses and were assigned to five principal aquifers, including Alluvial aquifers (Maupin and Barber, 2005) (appendix 2). Alluvial aquifers withdrawals (33.6 Mgal/d) accounted for about 20 percent of total principal aquifer withdrawals. Most of the Alluvial aquifers withdrawals (21.7 Mgal/d), which originated in alluvium in the eastern half of the state, were used for irrigation purposes. No withdrawals were from Other aquifers in Montana in 2000 (Maupin and Barber, 2005) (appendix 2).

Withdrawals of 7.24 Mgal/d from Alluvial aquifers were attributed to stream-valley aquifers associated with the Yellowstone River (6.84 Mgal/d) and the Little Missouri River $(0.40 \mathrm{Mgal} / \mathrm{d})$ in southeastern Montana (fig. 12, table 3). Most of the withdrawals (5.52 Mgal/d) from the stream-valley aquifers were for irrigation. Withdrawals of $26.3 \mathrm{Mgal} / \mathrm{d}$ from Alluvial aquifers could not be disaggregated and assigned to a specific aquifer or aquifer system; therefore, the withdrawals remained assigned to Alluvial aquifers (table 1). 


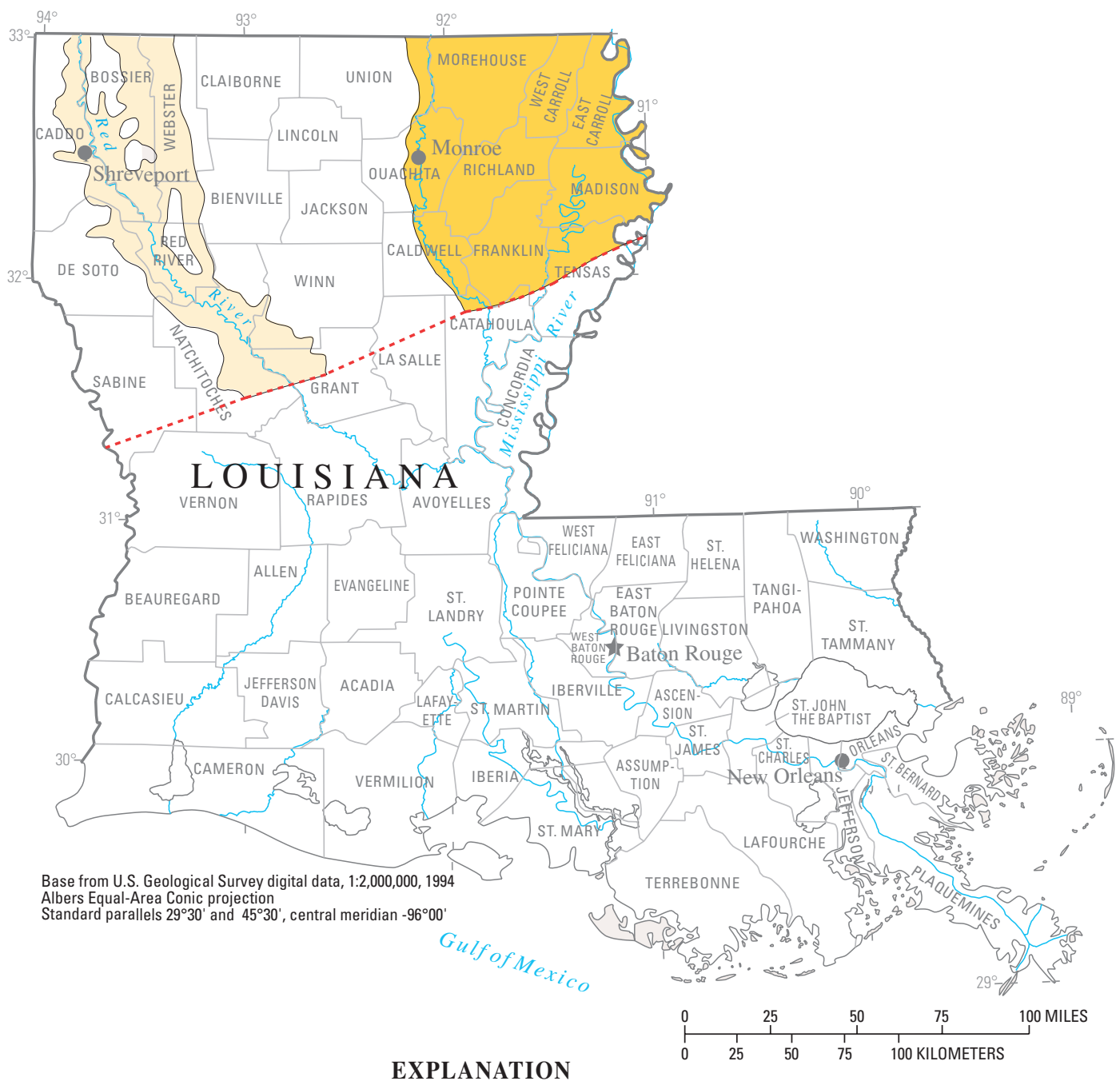

EXPLANATION

Surficial aquifer system

Mississippi River Valley alluvial aquifer

Red River alluvial aquifer

Approximate northern extent of the Coastal lowlands aquifer system

Figure 10. Extent of the Mississippi River Valley alluvial aquifer and the Red River alluvial aquifer in Louisiana where withdrawals from Alluvial aquifers were associated with stream-valley aquifers and other principal aquifers (source: Miller, 2000, fig. 23, p. F8). Withdrawals from stream-valley aquifers were identified from a subset of the alluvial deposits along the Red River.

\section{Nebraska}

In 2000, total ground-water withdrawals in Nebraska were about 7,860 Mgal/d (Hutson and others, 2004). About 98 percent $(7,720 \mathrm{Mgal} / \mathrm{d})$ of the withdrawals were for public-supply, self-supplied industrial, and irrigation uses, and assigned to four principal and Other aquifers (Maupin and Barber, 2005) (appendix 2). Withdrawals from Alluvial (150 Mgal/d) and Other (15.5 Mgal/d) aquifers accounted for about 2 percent of withdrawals from principal and Other aquifers (appendix 2). Most of the withdrawals from Alluvial aquifers were used for irrigation $(92.2 \mathrm{Mgal} / \mathrm{d})$; most of the withdrawals from Other aquifers $(10.3 \mathrm{Mgal} / \mathrm{d})$ were for public-supply use (appendix 2).

Only about 2 percent $(2.61 \mathrm{Mgal} / \mathrm{d})$ of the withdrawals from Alluvial aquifers in Nebraska were disaggregated and assigned to a specific stream-valley aquifer. The other approximately 98 percent of withdrawals (147 Mgal/d) remained assigned to Alluvial aquifers (table 1). Withdrawals from stream-valley aquifers were associated with the Big Blue (1.67 Mgal/d) and the Missouri (0.94 Mgal/d) Rivers (fig. 13, table 3). Most of the withdrawals were for 


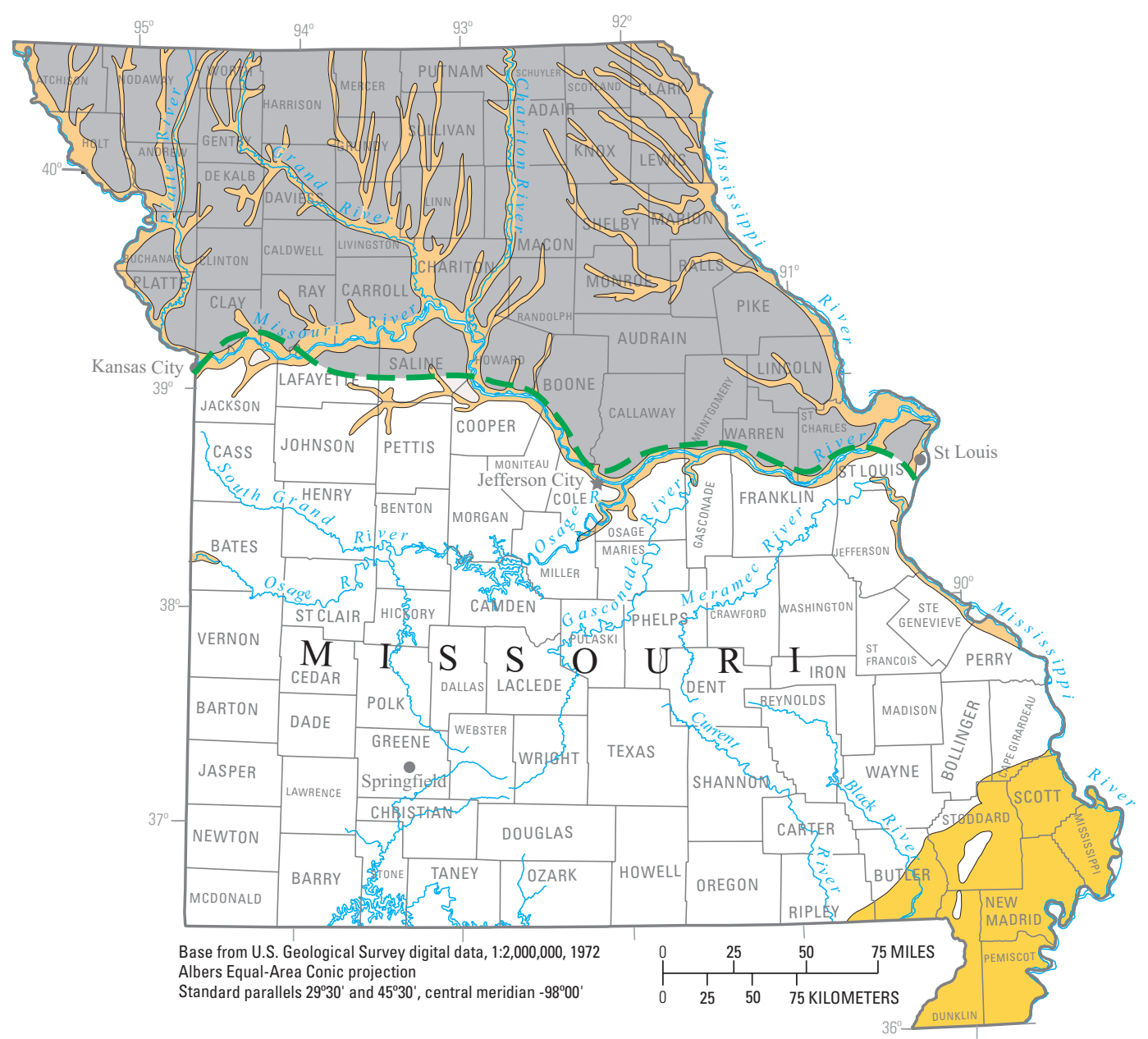

EXPLANATION

Coarse-grained glacial deposits, and streamvalley alluvium

Mississippi River Valley alluvial aquifer

Till, loess, and fine-grained glacial-lake deposits

Southern extent of Quaternary continental glaciation

Figure 11. Extent of alluvial deposits in Missouri where withdrawals from Alluvial aquifers were associated with stream-valley aquifers (source: Miller, 2000, fig. 4, p. D3). Withdrawals from stream-valley aquifers were identified from a subset of the alluvial deposits in the non-glaciated area north of the Mississippi River Valley alluvial aquifer, and also from small, unmapped stream-valley aquifers in Henry and St. Clair Counties.

self-supplied industrial (1.74 Mgal/d) and public-supply (0.80 Mgal/d) uses. No withdrawals from Other aquifers were attributed to stream-valley aquifers. All Other aquifer withdrawals (15.5 Mgal/d) were attributed to undifferentiated Pliocene-Pleistocene aquifers in southeastern Nebraska (table 4).

\section{New Jersey}

In 2000, total ground-water withdrawals for all categories of use in New Jersey were $584 \mathrm{Mgal} / \mathrm{d}$ (Hutson and others, 2004). About 84 percent ( $489 \mathrm{Mgal} / \mathrm{d}$ ) of the withdrawals were for public-supply, self-supplied industrial, and irrigation uses, and were assigned to seven principal aquifers (Maupin and Barber, 2005) (fig. 14, appendix 2). No withdrawals were assigned to Alluvial or Other aquifers in New Jersey in 2000 (Maupin and Barber, 2005), and no withdrawals were attributed to stream-valley aquifers.

\section{New Mexico}

In 2000, total ground-water withdrawals for all categories of use in New Mexico were 1,540 Mgal/d (Hutson and others, 2004). About 97 percent (1,500 Mgal/d) of the withdrawals 


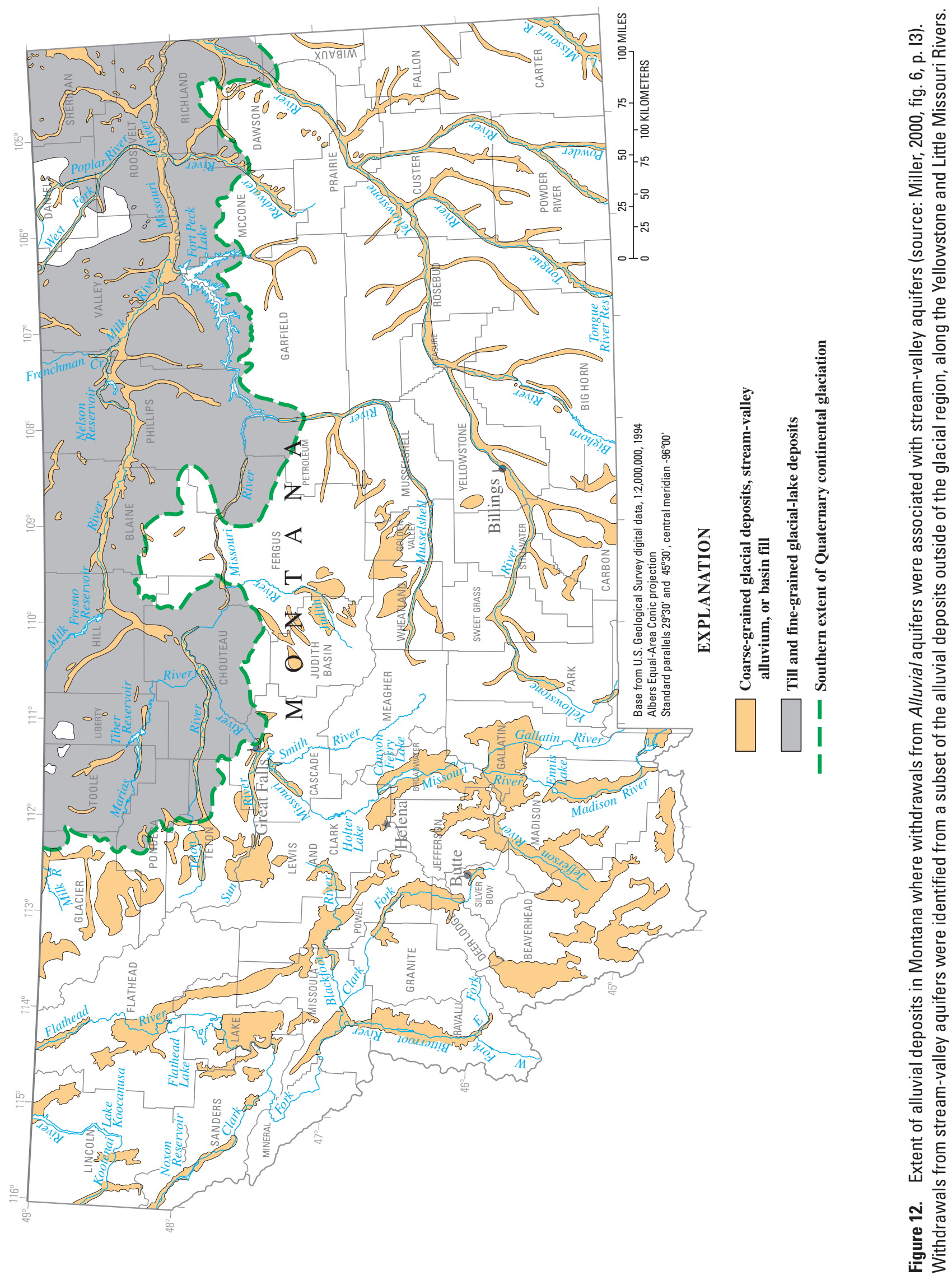




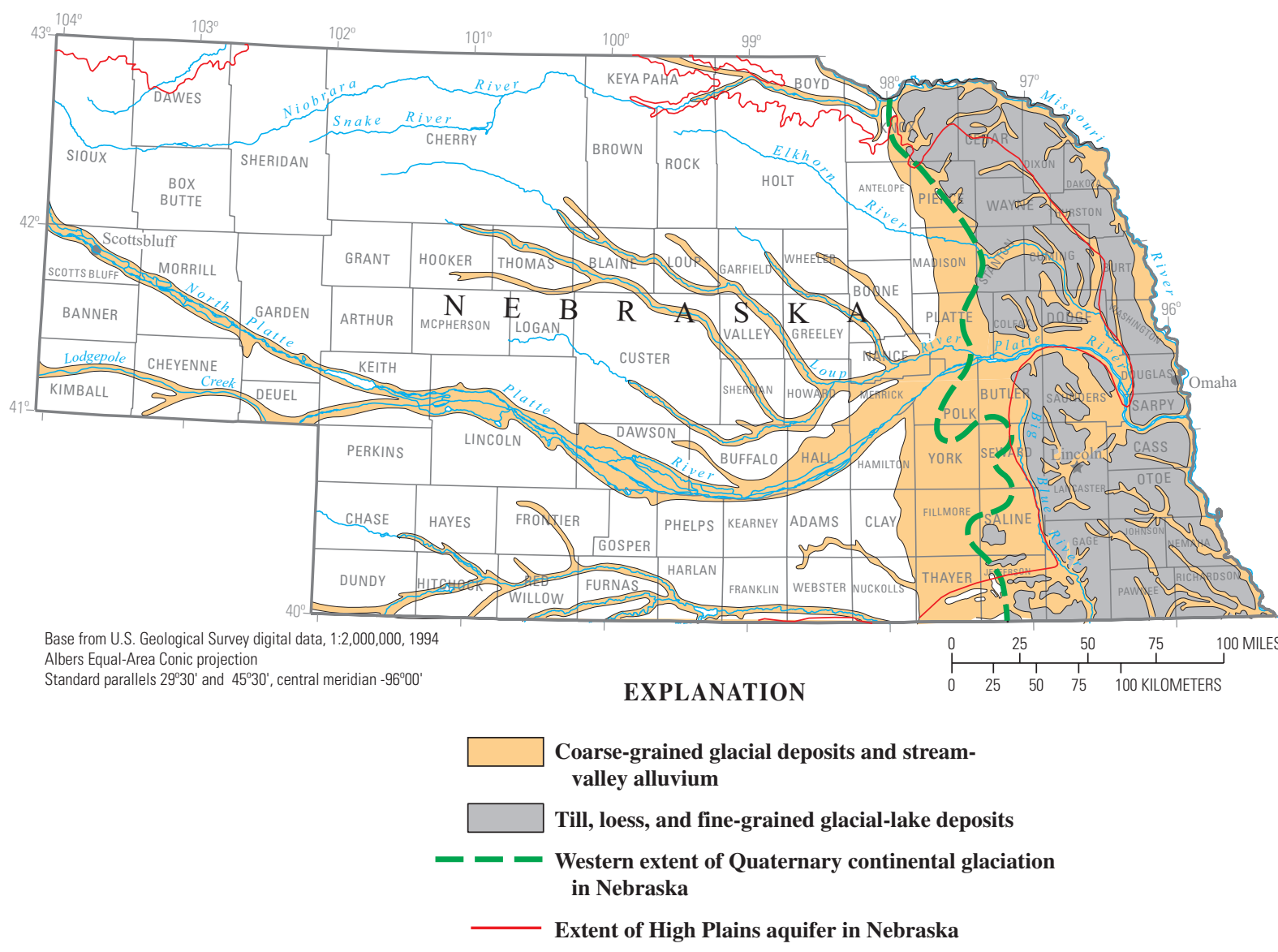

Figure 13. Extent of alluvial deposits in Nebraska where withdrawals from Alluvial aquifers were associated with stream-valley aquifers (source: Miller, 2000, fig. 4, p. D3). Stream-valley aquifer withdrawals were identified from a subset of the alluvial deposits east of the High Plains aquifer and outside the glaciated region. (See fig. 1 for full extent of the High Plains aquifer.)

were for public-supply, self-supplied industrial, and irrigation uses, and were assigned to six principal and Other aquifers (Maupin and Barber, 2005) (appendix 2). The use category with the largest withdrawals was irrigation $(1,230 \mathrm{Mgal} / \mathrm{d})$, mostly from the High Plains aquifer system (498 Mgal/d), the Roswell Basin aquifer system (364 Mgal/d), the Basin and Range basin-fill aquifers (164 Mgal/d), and the Rio Grande aquifer system (136 Mgal/d) (fig. 15, appendix 2). No withdrawals were assigned to Alluvial aquifers in New Mexico in 2000 (Maupin and Barber, 2005). Withdrawals from Other aquifers were $83.9 \mathrm{Mgal} / \mathrm{d}$ and accounted for about 6 percent of withdrawals from principal and Other aquifers for the three uses. No withdrawals from Other aquifers could be attributed to stream-valley aquifers in New Mexico.

\section{New York}

In 2000, total ground-water withdrawals for all categories of use in New York were $893 \mathrm{Mgal} / \mathrm{d}$ (Hutson and others,
2004). About 84 percent ( $752 \mathrm{Mgal} / \mathrm{d})$ of the withdrawals were for public-supply, self-supplied industrial, and irrigation uses and were assigned to five principal and Other aquifers (Maupin and Barber, 2005) (appendix 2). No withdrawals were assigned to Alluvial aquifers in New York in 2000 (Maupin and Barber, 2005). Withdrawals from Other aquifers $(25.2 \mathrm{Mgal} / \mathrm{d})$ accounted for about 3 percent of total withdrawals from principal and Other aquifers (appendix 2). Withdrawals from Other aquifers were mostly for self-supplied industrial (15.8 Mgal/d) and public-supply $(9.20 \mathrm{Mgal} / \mathrm{d})$ uses (appendix 2).

In Cattaraugus County, New York, withdrawals of 4.07 Mgal/d in an area of glacial sand and gravel aquifers were assigned to a stream-valley aquifers associated with the Allegheny River (fig. 16). All of the withdrawals were for public-supply uses (table 3 ) and resulted in an estimated reduction of withdrawals from glacial sand and gravel aquifers by less than 2 percent, to $259 \mathrm{Mgal} / \mathrm{d}$ (table 1). No withdrawals from $O$ ther aquifers were attributed to stream-valley aquifers. 


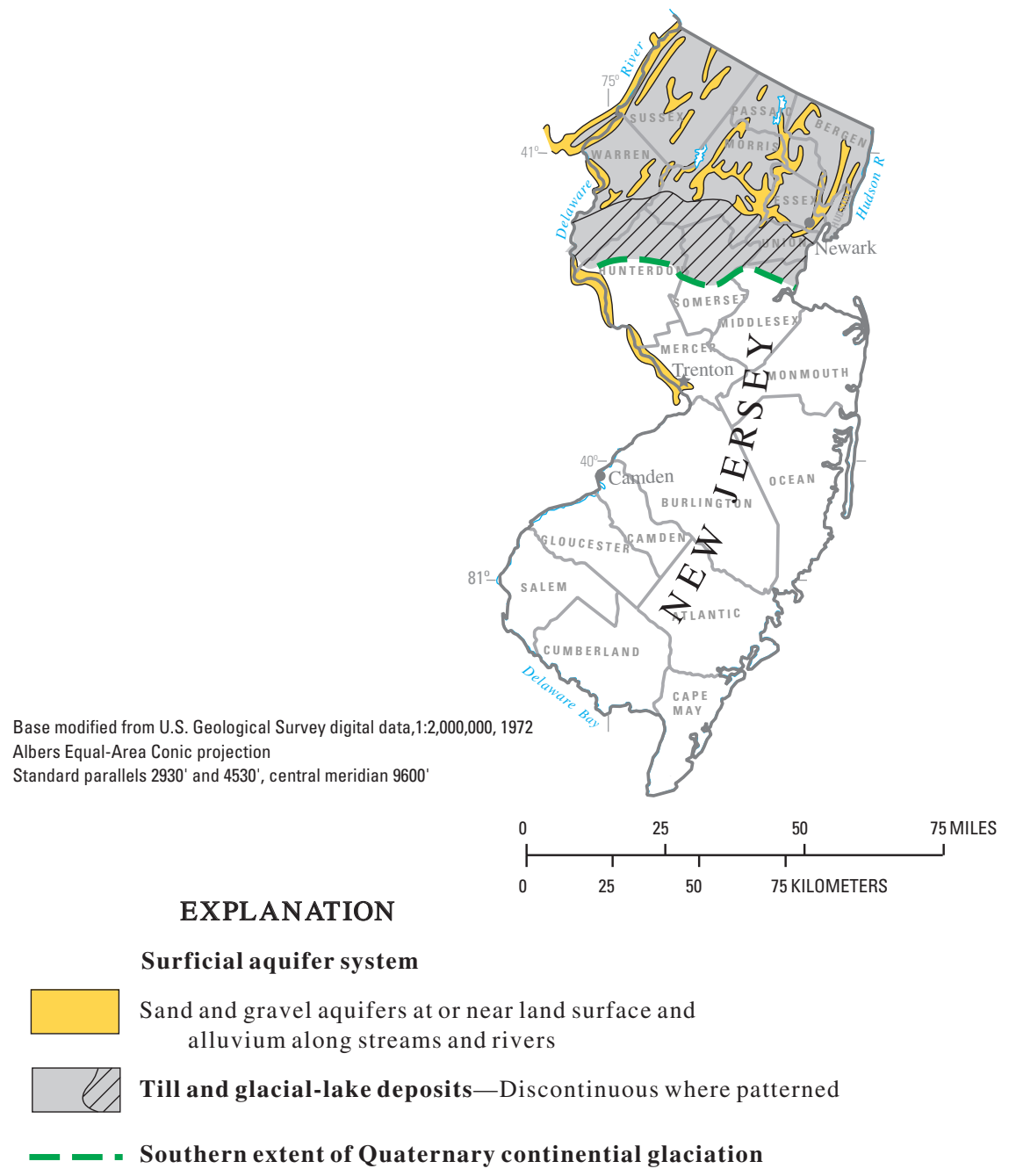

Figure 14. Extent of alluvial deposits in New Jersey where stream-valley aquifer withdrawals were investigated (source: Miller, 2000, fig. 6, p. L3).

\section{North Dakota}

In 2000, total ground-water withdrawals for all categories of use in North Dakota were $123 \mathrm{Mgal} / \mathrm{d}$ (Hutson and others, 2004). About 91 percent (112 Mgal/d) of the withdrawals were for public-supply, self-supplied industrial, and irrigation uses, and were assigned to three principal and Other aquifers (Maupin and Barber, 2005) (appendix 2). Most of the withdrawals $(76.0 \mathrm{Mgal} / \mathrm{d})$ in North Dakota were derived from glacial sand and gravel aquifers (appendix 2). Withdrawals from Alluvial (23.2 Mgal/d) and Other (7.06 Mgal/d) aquifers accounted for approximately 27 percent of withdrawals from principal aquifers and Other aquifers (appendix 2). Alluvial aquifer withdrawals were used mostly for irrigation (15.6 Mgal/d), and Other aquifer withdrawals were used mostly for public supply (4.28 Mgal/d).

Withdrawals from Alluvial aquifers in North Dakota could not be attributed to stream-valley aquifers. However, all withdrawals from Alluvial aquifers were disaggregated to aquifers and aquifer units that were north of the extent of Quaternary continental glaciation and, in some instances, identified as being a buried stream channel (appendix 3). The relatively small amount of withdrawals attributed to Other aquifers (7.06 Mgal/d) was attributed to aquifers and aquifer units in areas north of the southern extent of Quaternary continental glaciation (fig. 17, appendix 2). No withdrawals from Other aquifers were assigned to stream-valley aquifers.

\section{Ohio}

In 2000, total ground-water withdrawals for all categories of use in Ohio for 2000 were $878 \mathrm{Mgal} / \mathrm{d}$ (Hutson and others, 2004). About 77 percent (676 Mgal/d) of the withdrawals were for public-supply, self-supplied industrial, and irrigation uses, and were assigned to five principal and Other 


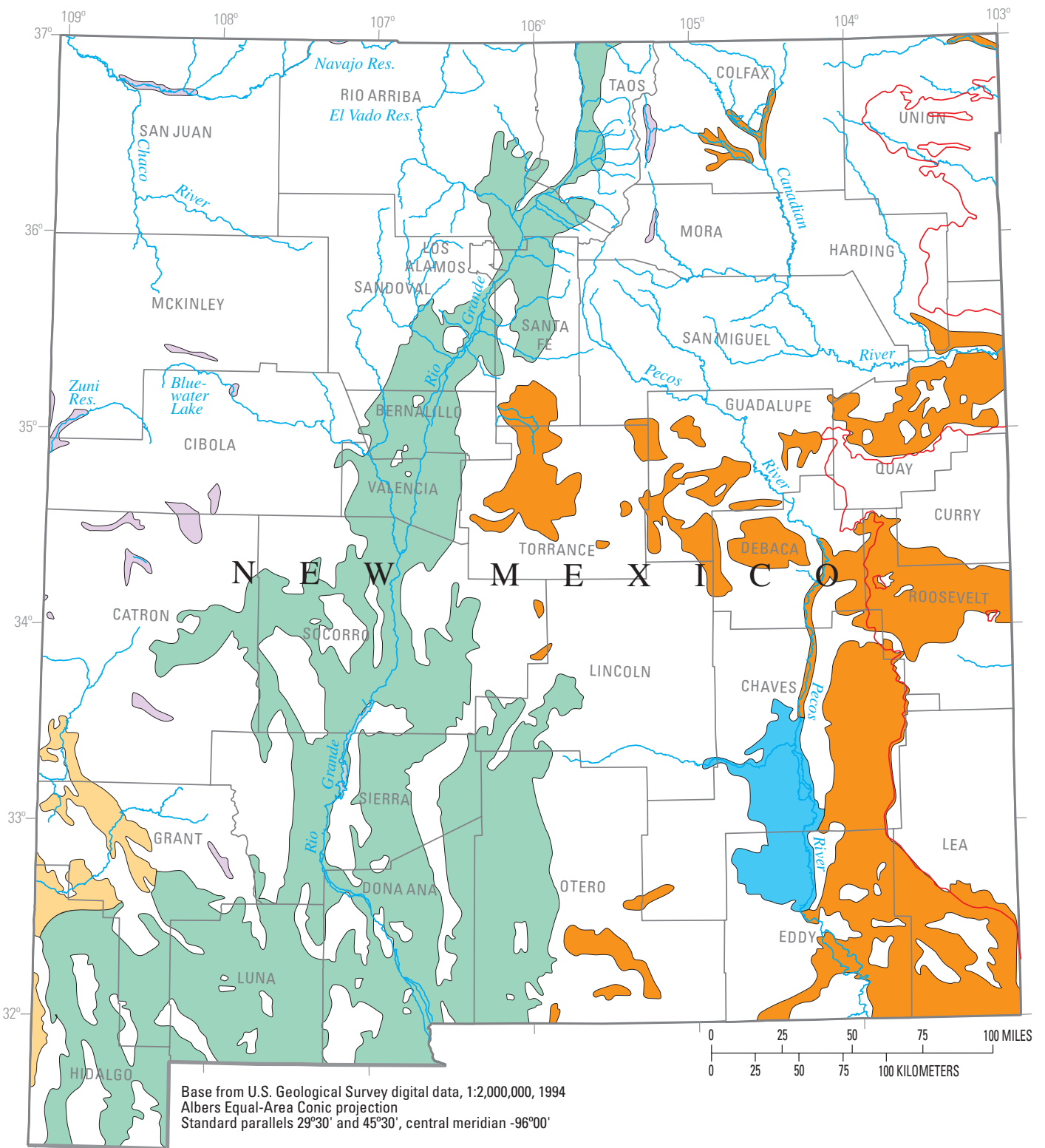

EXPLANATION

Extent of alluvial or eolian deposits

Mountainous area

Upland plains area

Basin and Range area

Rio Grande basin area

Roswell Basin area

Extent of High Plains aquifer in New Mexico

Figure 15. Extent of alluvial deposits in New Mexico where stream-valley aquifer withdrawals were investigated (source: Miller, 2000, fig. 18, p. C7). (See fig. 1 for full extent of the High Plains aquifer.) 


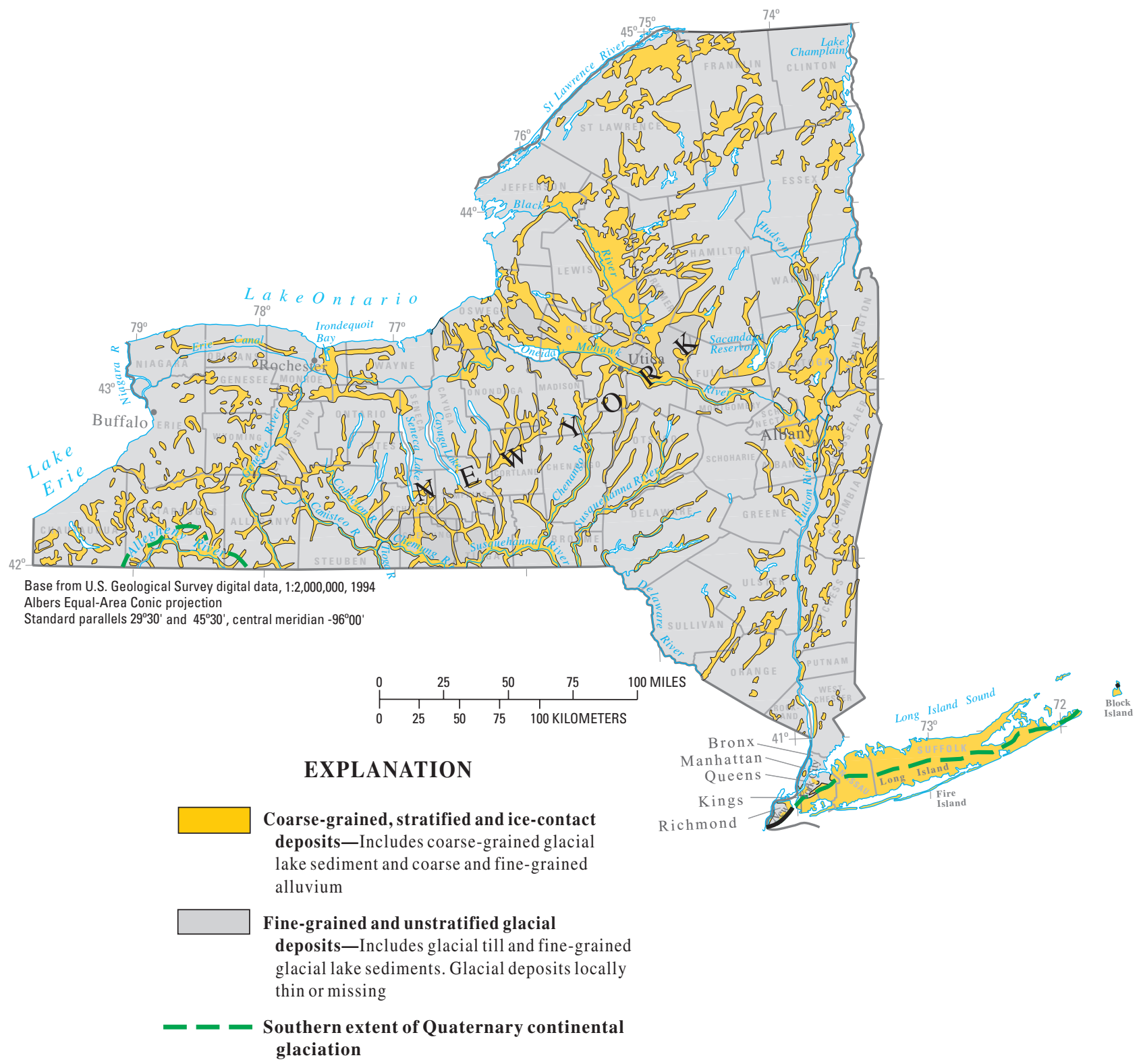

Figure 16. Extent of alluvial deposits in New York that were evaluated for possible withdrawals from stream-valley aquifers (source: Miller, 2000, fig. 9, p. M4). Some of the withdrawals from glacial sand and gravel aquifers were attributed to stream-valley aquifers in a subset of the sediments in the non-glaciated area.

aquifers (Maupin and Barber, 2005) (appendix 2). Withdrawals from Alluvial (53.0 Mgal/d) and Other (5.81 Mgal/d) aquifers accounted for about 9 percent of the total withdrawals from principal and $O$ ther aquifers. Withdrawals were used mostly for public supply from Alluvial aquifers (39.4 Mgal/d), and to a similar degree from Other aquifers $(4.35 \mathrm{Mgal} / \mathrm{d})$ (appendix 2). About 62 percent (421 Mgal/d) of withdrawals from principal and Other aquifers in Ohio were attributed to the glacial sand and gravel aquifers (appendix 2).

Alluvial aquifers withdrawals $(53.0 \mathrm{Mgal} / \mathrm{d})$ could not be attributed to stream-valley aquifers in Ohio (table 1).
Withdrawals of $100 \mathrm{Mgal} / \mathrm{d}$ from glacial sand and gravel aquifers were disaggregated to stream-valley aquifers associated with various streams south of the extent of Quaternary continental glaciation (fig. 18, table 3). The reassignment reduced withdrawals from glacial sand and gravel aquifers in Ohio about 24 percent, from 421 to $321 \mathrm{Mgal} / \mathrm{d}$ (table 1). No withdrawals from Other aquifers were attributed to stream-valley aquifers in Ohio. Total withdrawals of $5.81 \mathrm{Mgal} / \mathrm{d}$ from the Other aquifers were attributed to Cambrian-Ordovician and unknown aquifers in Ohio (table 4). 


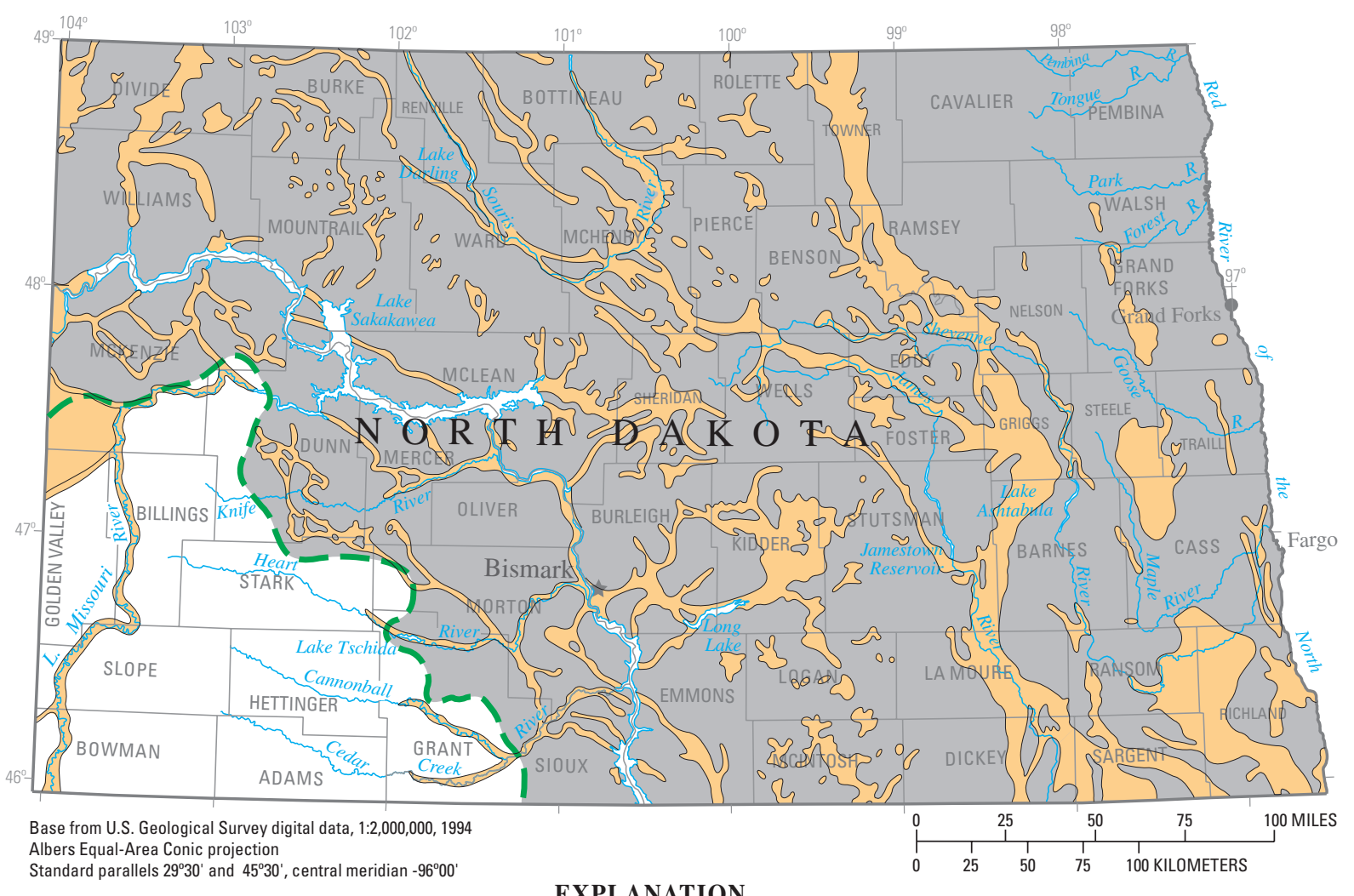

EXPLANATION

Coarse-grained glacial deposits, streamvalley alluvium, or basin fill

Till, loess, and fine-grained glacial-lake deposits

- Southern extent of Quaternary continental glaciation

Figure 17. Extent of alluvial deposits in North Dakota where stream-valley aquifer withdrawals were investigated (source: Miller, 2000, fig. 6, p. 13). These sediments were evaluated for possible withdrawals associated with stream-valley aquifers. Although withdrawals from stream-valley aquifers may occur in North Dakota, no withdrawals could be definitively attributed to stream-valley aquifers.

\section{Oklahoma}

In 2000, total fresh ground-water withdrawals for all categories of use in Oklahoma were $771 \mathrm{Mgal} / \mathrm{d}$ (Hutson and others, 2004). About 89 percent (686 Mgal/d) of the withdrawals were for public-supply, self-supplied industrial, and irrigation uses, and were assigned to nine principal and Other aquifers (Maupin and Barber, 2005) (appendix 2). Withdrawals from Alluvial (128 Mgal/d) and Other (19.3 Mgal/d) aquifers accounted for about 21 percent of withdrawals from principal aquifers and Other in Oklahoma in 2000 (appendix 2). Withdrawals were used mostly for irrigation from Alluvial aquifers (74.9 Mgal/d), and to a greater degree from Other aquifers (13.3 Mgal/d) (appendix 2).

All the withdrawals assigned to Alluvial aquifers in Oklahoma were disaggregated (tables 1 and 3). Withdrawals of $126 \mathrm{Mgal} / \mathrm{d}$ from Alluvial aquifers were attributed to six stream-valley aquifers associated with the Red (31.5 Mgal/d),
Arkansas (26.0 Mgal/d), Cimarron (25.1 Mgal/d), North Canadian (24.3 Mgal/d), Canadian (12.9 Mgal/d), and Washita (6.38 Mgal/d) Rivers (fig. 19, table 3). About 97 percent of the withdrawals were for irrigation $(74.2 \mathrm{Mgal} / \mathrm{d})$ and publicsupply (48.4 Mgal/d) uses (fig. 19, table 3). Withdrawals of $1.62 \mathrm{Mgal} / \mathrm{d}$ from Alluvial aquifers were disaggregated to five isolated, elevated terrace deposits that are disconnected from surface-water features but are still classified as Alluvial aquifers (table 3 ).

No withdrawals from Other aquifers in Oklahoma were attributed to stream-valley aquifers, but withdrawals were disaggregated to 31 aquifers or water-bearing units (table 4). Most of the withdrawals from Other aquifers were for public-supply (5.83 Mgal/d) and irrigation (13.3 Mgal/d) uses (table 4). About 42 percent (8.02 Mgal/d) of withdrawals from $O$ ther aquifers were attributed to the water-bearing unit, Cretaceous System. 


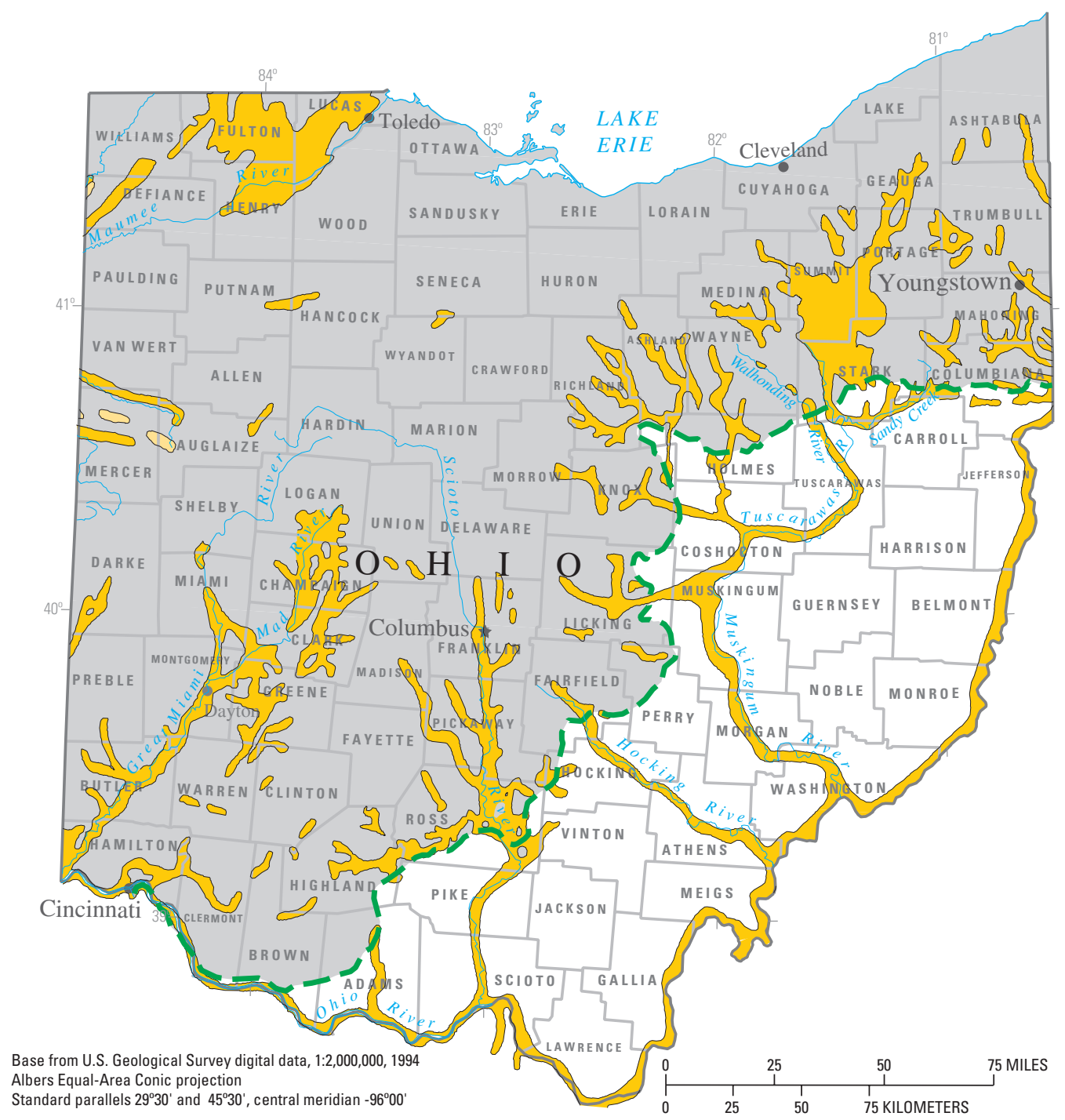

EXPLANATION

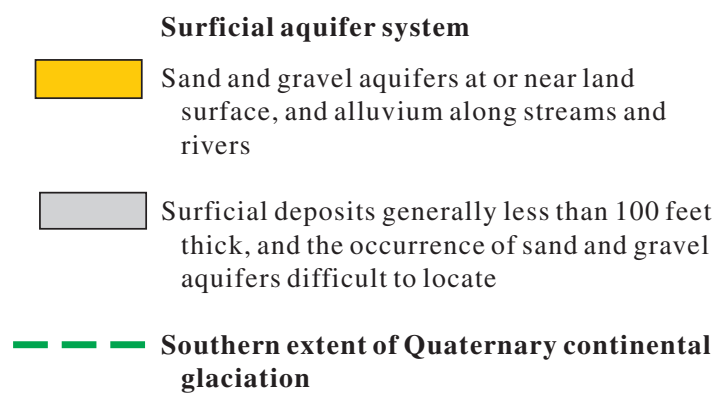

Figure 18. Extent of alluvial deposits in Ohio that were evaluated for possible withdrawals associated with stream-valley aquifers (source: Miller, 2000, fig. 4, p. K3). Some of the withdrawals from glacial sand and gravel aquifers were attributed to stream-valley aquifers in a subset of the sediments in the non-glaciated area. 


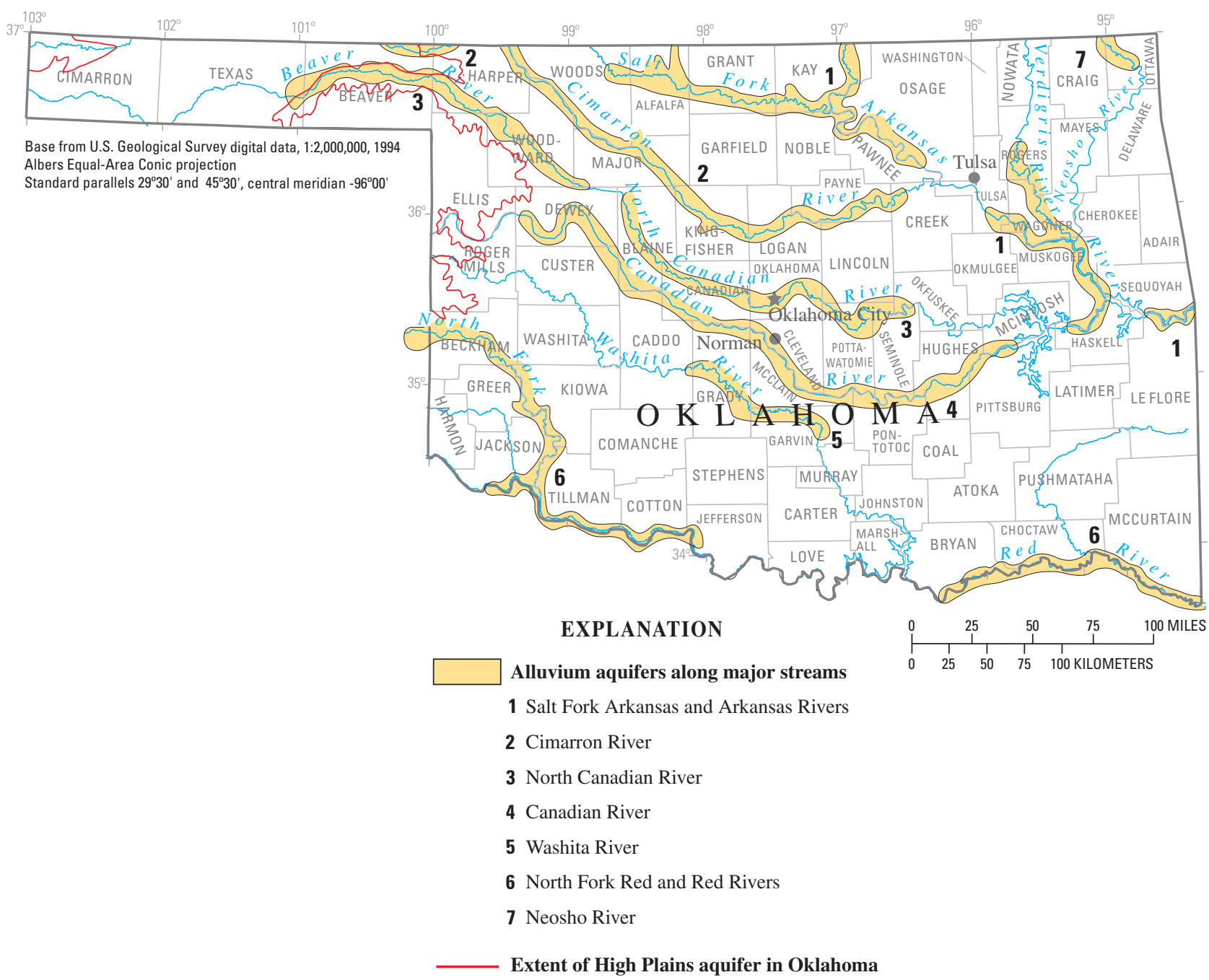

Figure 19. Extent of alluvial deposits along major streams in Oklahoma where withdrawals from Alluvial aquifers were associated with stream-valley aquifers (source: Miller, 2000, fig. 11, p. E6). Withdrawals from stream-valley aquifers were identified from a subset of the alluvial deposits east of the High Plains aquifer. (See fig. 1 for full extent of the High Plains aquifer.)

\section{Pennsylvania}

In 2000, total ground-water withdrawals for all categories of use in Pennsylvania were $666 \mathrm{Mgal} / \mathrm{d}$ (Hutson and others, 2004). About 55 percent (368 Mgal/d) of the withdrawals were for public-supply, self-supplied industrial, and irrigation uses, and were assigned to nine principal aquifers, including Pennsylvanian aquifers and Other aquifers (Maupin and Barber (2005) (appendix 2). No withdrawals were assigned to Alluvial aquifers in Pennsylvania in 2000. Withdrawals from Other aquifers were about 30 percent (109 Mgal/d) of total withdrawals from principal and $O$ ther aquifers, and were $81.0 \mathrm{Mgal} / \mathrm{d}$ for public-supply, 28.2 Mgal/d for self-supplied industrial, and $0.10 \mathrm{Mgal} / \mathrm{d}$ for irrigation uses (appendix 2).
Withdrawals from Pennsylvanian (28.1 Mgal/d) and Other (42.1 Mgal/d) aquifers were disaggregated to streamvalley aquifers associated with the Allegheny (39.4 Mgal/d), Ohio (25.9 Mgal/d), Monongahela (3.35 Mgal/d), Beaver $(1.43 \mathrm{Mgal} / \mathrm{d})$, and Delaware $(0.1 \mathrm{Mgal} / \mathrm{d})$ Rivers, and other miscellaneous rivers (0.01 Mgal/d) (fig. 20, table 3). Withdrawals from all of these rivers were mostly for self-supplied industrial (44.6 Mgal/d) and public-supply (25.6 Mgal/d) uses. The disaggregation of withdrawals to stream-valley aquifers reduced withdrawals from the Pennsylvanian aquifers in Pennsylvania by 64 percent to $15.5 \mathrm{Mgal} / \mathrm{d}$, and withdrawals from Other aquifers in Pennsylvania by 39 percent to $67.2 \mathrm{Mgal} / \mathrm{d}$ (table 1). 


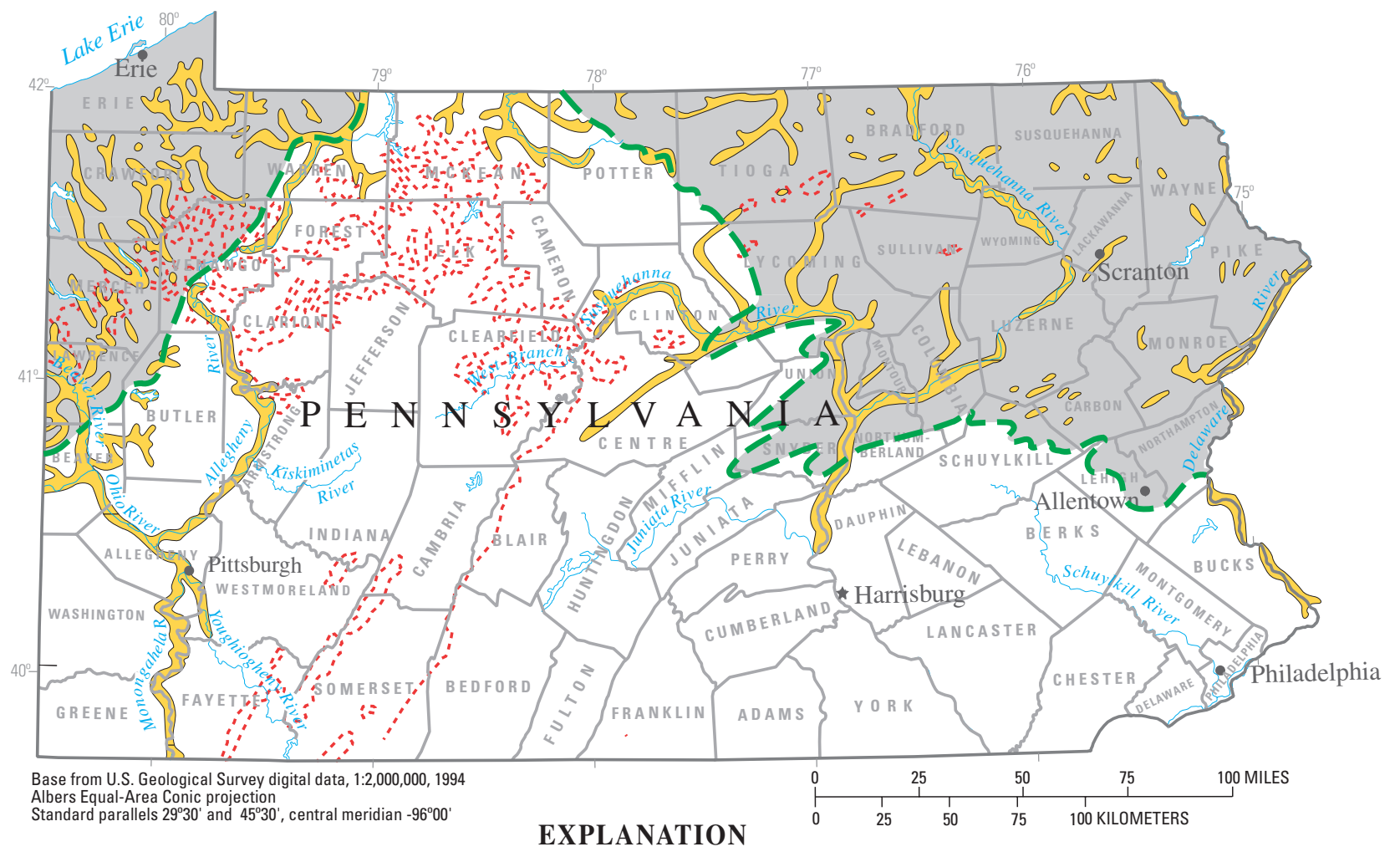

EXPLANATION

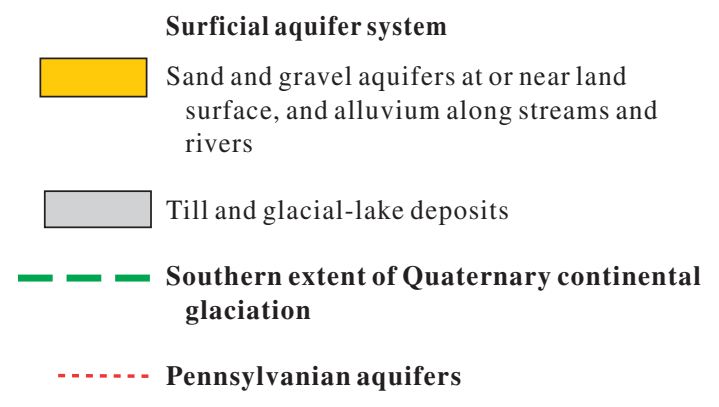

Figure 20. Extent of alluvial deposits in Pennsylvania that were evaluated for possible withdrawals associated with stream-valley aquifers (source: Miller, 2000, fig. 6, p. L3). Some of the withdrawals previously associated with Other and Pennsylvanian aquifers in the non-glaciated area were attributed to stream-valley aquifers.

\section{Puerto Rico}

In 2000, total ground-water withdrawals for all categories of use in Puerto Rico were $137 \mathrm{Mgal} / \mathrm{d}$ (Hutson and others, 2004). About 99 percent (135 Mgal/d) of the withdrawals were for public-supply, self-supplied industrial, and irrigation uses, and were assigned to two principal (fig. 21) and Other aquifers (Maupin and Barber, 2005) (appendix 2). No withdrawals were assigned to Alluvial aquifers in Puerto Rico in 2000. Withdrawals from Other aquifers were $33.2 \mathrm{Mgal} / \mathrm{d}$, which accounted for about 25 percent of withdrawals from principal and Other aquifers for the three uses (appendix 2). Withdrawals from Other aquifers included 16.2 Mgal/d for public-supply, 14.4 Mgal/d for irrigation, and $2.60 \mathrm{Mgal} / \mathrm{d}$ for self-supplied industrial uses. No withdrawals could be attributed to stream-valley aquifers in Puerto Rico (fig. 21).

\section{South Dakota}

In 2000, total ground-water withdrawals for all categories of use in South Dakota were $222 \mathrm{Mgal} / \mathrm{d}$ (Hutson and others, 2004). About 88 percent (195 Mgal/d) of the withdrawals were for public-supply, self-supplied industrial, and irrigation uses, and were assigned to five principal aquifers, including glacial sand and gravel aquifers, Alluvial aquifers, and Other aquifers (Maupin and Barber, 2005) (appendix 2). Withdrawals from Alluvial aquifers accounted for 21 percent (40.2 Mgal/d) of the withdrawals from principal aquifers and 


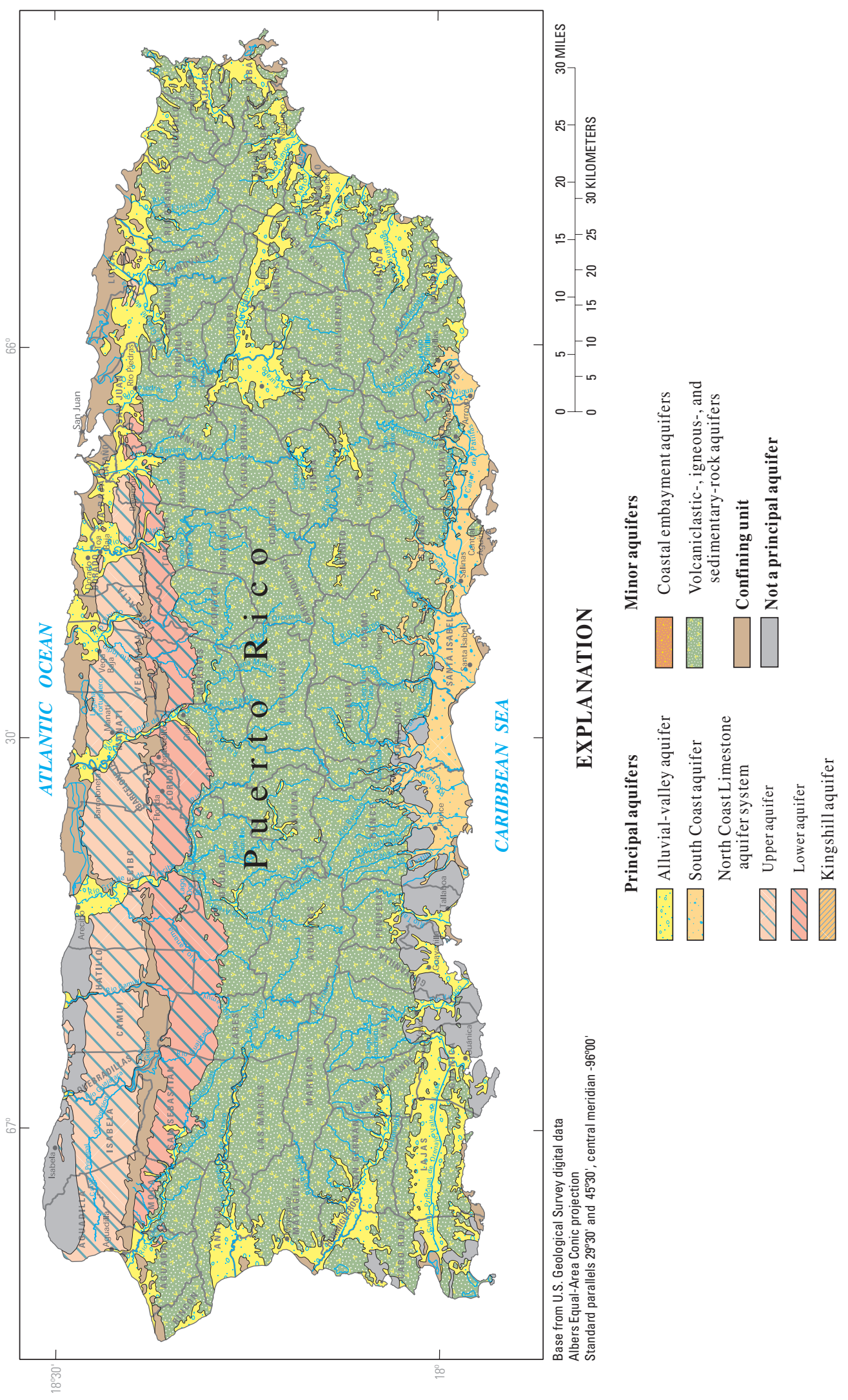


Other aquifers (appendix 2). About 62 percent (24.9 Mgal/d) of withdrawals from Alluvial aquifers were for irrigation uses. Glacial sand and gravel aquifers provided about 60 percent $(118 \mathrm{Mgal} / \mathrm{d})$ of the withdrawals from principal and Other aquifers for the three uses. Withdrawals from Other aquifers were only $1.90 \mathrm{Mgal} / \mathrm{d}$ in South Dakota in 2000 (appendix 2).

Withdrawals of $13.6 \mathrm{Mgal} / \mathrm{d}$ from Alluvial aquifers were disaggregated to stream-valley aquifers associated with the Cheyenne River (13.4 Mgal/d), White River (0.10 Mgal/d), Bear Butte Creek (0.08 Mgal/d), and Belle Fourche River (0.01 Mgal/d) (fig. 22, table 3). Most of the withdrawals were from stream-valley aquifers associ- ated with the Cheyenne River, mostly for public-supply (13.2 Mgal/d) and self-supplied industrial (0.14 Mgal/d) uses (table 3).

About 66 percent of Alluvial aquifers withdrawals (26.6 Mgal/d) remained assigned to Alluvial aquifers (table 1). Nearly all of the revised total Alluvial aquifers withdrawals (26.5 Mgal/d) were attributed to Alluvial aquifer withdrawals in areas north of the line of Quaternary continental glaciation which generally follows the Missouri River (fig. 22, table 3). Most of these withdrawals $(24.5 \mathrm{Mgal} / \mathrm{d})$ were for irrigation. Irrigation withdrawals of $0.1 \mathrm{Mgal} / \mathrm{d}$ from Alluvial aquifers could not be disaggregated and assigned to a specific aquifer or aquifer system (table 3 ).

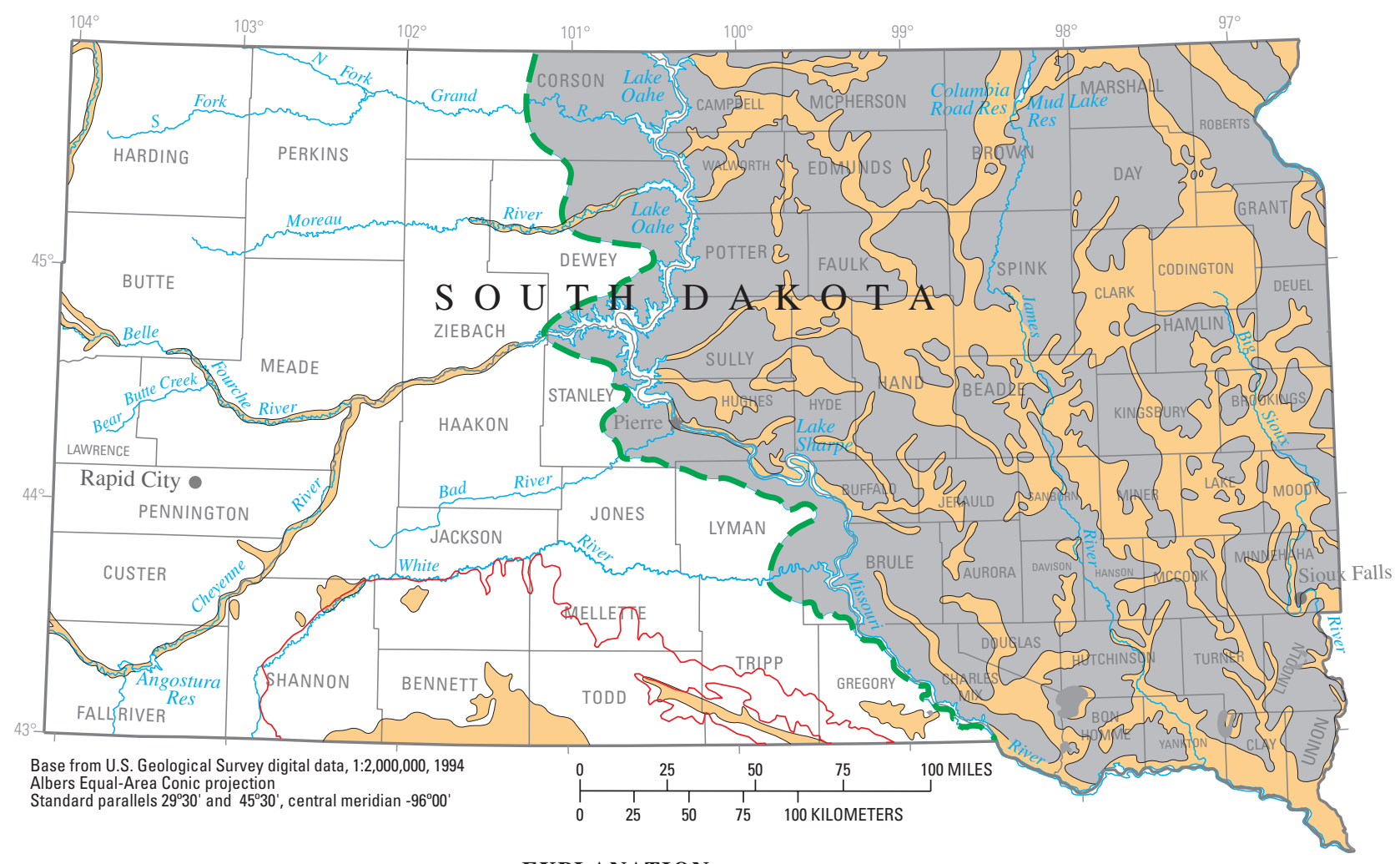

EXPLANATION

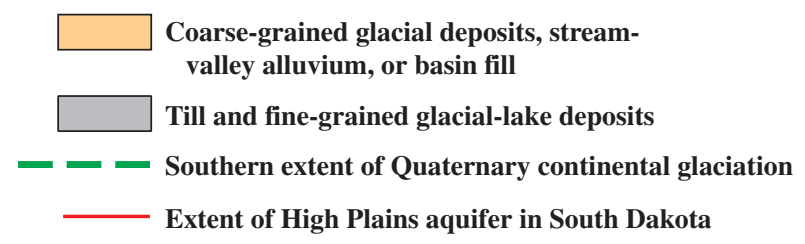

Figure 22. Extent of coarse-grained glacial deposits, stream-valley alluvium, and basin fill in South Dakota where withdrawals from Alluvial aquifers were associated with stream-valley aquifers (source: Miller, 2000, fig. 6, p. I3). Withdrawals from stream-valley aquifers were identified from a subset of the alluvial deposits north of the High Plains aquifer and outside of the glaciated region. (See fig. 1 for full extent of the High Plains aquifer.) 


\section{Tennessee}

In 2000, total ground-water withdrawals for all categories of use in Tennessee were $417 \mathrm{Mgal} / \mathrm{d}$ (Hutson and others, 2004). About 92 percent ( $385 \mathrm{Mgal} / \mathrm{d}$ ) of the withdrawals were for public-supply, self-supplied industrial, and irrigation uses, and were assigned to eight principal and Other aquifers (Maupin and Barber, 2005) (appendix 2). Withdrawals from Alluvial and Other aquifers totaled $2.48 \mathrm{Mgal} / \mathrm{d}$, representing less than 1 percent of total withdrawals from principal and Other aquifers (appendix 2). Withdrawals were used mostly for public supply (2.40 Mgal/d) from Alluvial aquifers and mostly for irrigation $(0.04 \mathrm{Mgal} / \mathrm{d})$ from Other aquifers (appendix 2).

Public supply withdrawals of $2.30 \mathrm{Mgal} / \mathrm{d}$ from Alluvial aquifers were attributed to a stream-valley aquifer associated with the Tennessee River (fig. 23, table 3). Withdrawals of $0.13 \mathrm{Mgal} / \mathrm{d}$ from Alluvial aquifers could not be disaggregated and assigned to a specific aquifer or aquifer system (tables 1 and 3). No withdrawals from Other aquifers could be assigned to stream-valley aquifers, but withdrawals were attributed to the Knox Dolomite (table 4).

\section{Texas}

In 2000, total fresh ground-water withdrawals for all categories of use in Texas were 8,470 Mgal/d (Hutson and others, 2004). About 95 percent (8,010 Mgal/d) of the withdrawals were for public-supply, self-supplied industrial, and irrigation uses, and were assigned to nine principal and Other aquifers (Maupin and Barber, 2005) (appendix 2). Withdrawals from Alluvial (12.6 Mgal/d) and Other (310 Mgal/d) aquifers accounted for about 4 percent of withdrawals from principal and Other aquifers. Withdrawals were used mostly for irrigation from Alluvial aquifers (12.6 Mgal/d) and, to a lesser degree, from Other aquifers (283 Mgal/d) (appendix 2).

Alluvial aquifers supplied a small fraction ( 0.16 percent $)$ of total withdrawals from aquifers in Texas (appendix 2). All withdrawals from Alluvial aquifers in Texas (12.6 Mgal/d) were attributed to a stream-valley aquifer associated with the Brazos River (fig. 24, table 1), and were used mostly for irrigation (table 3). No withdrawals from Other aquifers were attributed to stream-valley aquifers, but all withdrawals from Other aquifers were disaggregated to 13 aquifers and waterbearing units, (table 4). About 66 percent of the withdrawals from Other aquifers were attributed to the Bone Spring Limestone (204 Mgal/d). About 91 percent $(283 \mathrm{Mgal} / \mathrm{d})$ of withdrawals from Other aquifers were for irrigation use.

\section{Utah}

In 2000, total fresh ground-water withdrawals for all categories of use in Utah were 1,020 Mgal/d (Hutson and others, 2004). About 85 percent ( $868 \mathrm{Mgal} / \mathrm{d}$ ) of the withdrawals were for public-supply, self-supplied industrial, and irrigation uses, and were assigned to five principal aquifers, including Alluvial aquifers, Basin and Range basin-fill aquifers, and Other aquifers (Maupin and Barber, 2005). Withdrawals from Alluvial and Other aquifers accounted for 7 percent $(63.3 \mathrm{Mgal} / \mathrm{d})$ of withdrawals from principal and Other aquifers for the three categories of use (appendix 2). About 78 percent (679 Mgal/d) of the withdrawals were from Basin and Range basin-fill aquifers and were mostly for irrigation (439 Mgal/d) and publicsupply (208 Mgal/d) uses. Withdrawals from Alluvial aquifers

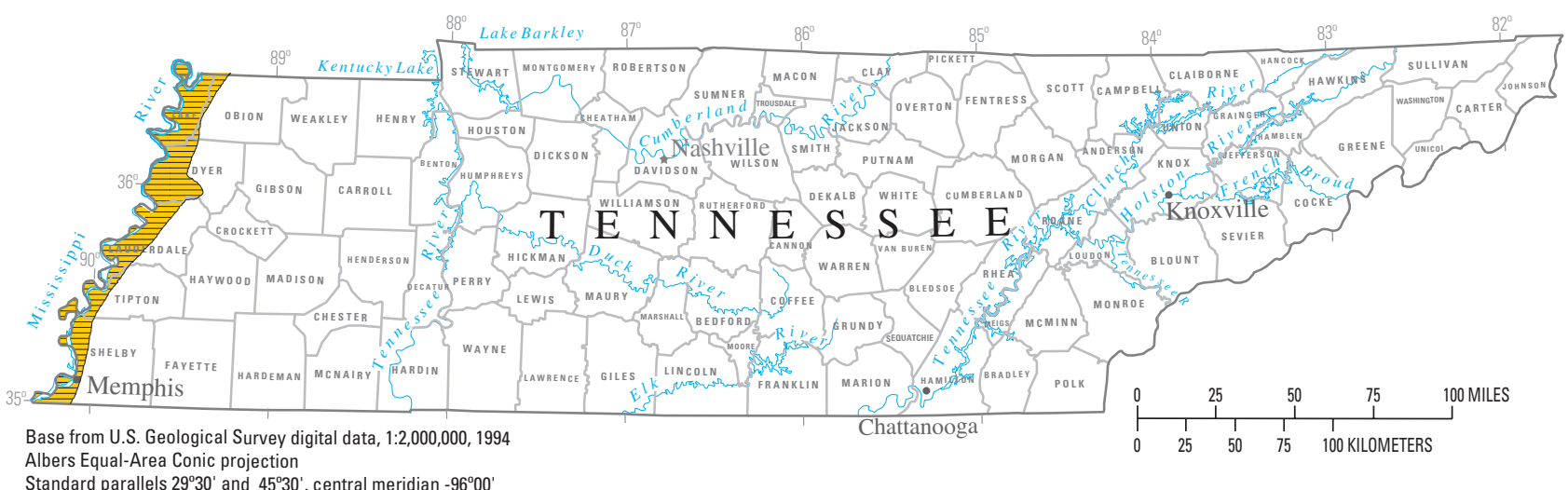

Standard parallels $29^{\circ} 30^{\prime}$ and $45^{\circ} 30^{\prime}$, central meridian $-96^{\circ} 00^{\prime}$

\section{EXPLANATION}

Surficial aquifer system

Mississippi River Valley alluvial aquifer

Figure 23. The surficial aquifer system in Tennessee that consists mainly of the Mississippi River Valley alluvial aquifer. No withdrawals from the Mississippi River Valley alluvial aquifer were disaggregated to stream-valley aquifers. Some withdrawals from Alluvial aquifers were disaggregated to stream-valley aquifers associated with the Tennessee River (source: Miller, 2000, fig. 4, p. K3). 


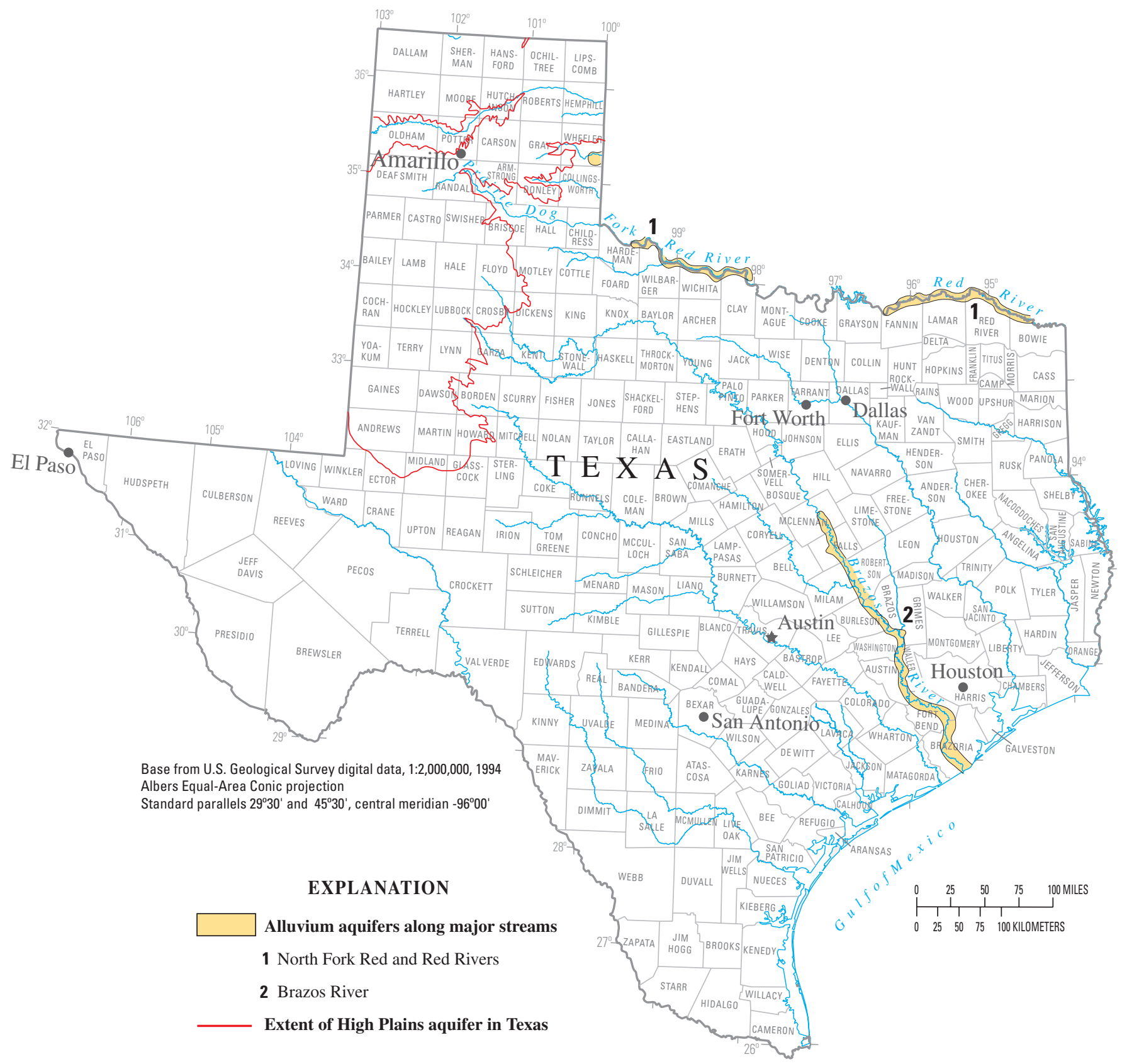

Figure 24. Extent of alluvial deposits along major streams in Texas where withdrawals from Alluvial aquifers were associated with stream-valley aquifers (source: Miller, 2000, fig. 11, p. E6). Withdrawals from stream-valley aquifers were identified from a subset of the alluvial deposits east of the High Plains aquifer. (See fig. 1 for full extent of the High Plains aquifer.)

were used mostly for irrigation (22.9 Mgal/d). Withdrawals from Other aquifers were used mostly for public-supply (31.7 Mgal/d) (appendix 2).

Withdrawals of $24.8 \mathrm{Mgal} / \mathrm{d}$ from Alluvial aquifers in Utah were disaggregated to stream-valley aquifers associated with seven major rivers (fig. 25, table 3). Stream-valley aquifer withdrawals were mostly for irrigation (19.9 Mgal/d) and public-supply (4.48 Mgal/d) uses. About 82 percent of streamvalley aquifer withdrawals were from the Sevier (17.3 Mgal/d) and Fremont (3.12 Mgal/d) Rivers and were used mostly for irrigation.

Withdrawals of $0.77 \mathrm{Mgal} / \mathrm{d}$ from the Basin and Range basin-fill aquifers (fig. 25, table 1) were reassigned to Alluvial aquifers. The reassignment increased withdrawals from Alluvial aquifers for public-supply use from 8.20 to $8.97 \mathrm{Mgal} / \mathrm{d}$ in Utah in 2000, and decreased withdrawals from Basin and Range basin-fill aquifers for public-supply use from 208 to $207 \mathrm{Mgal} / \mathrm{d}$. Consequently, the revised total withdrawals for 


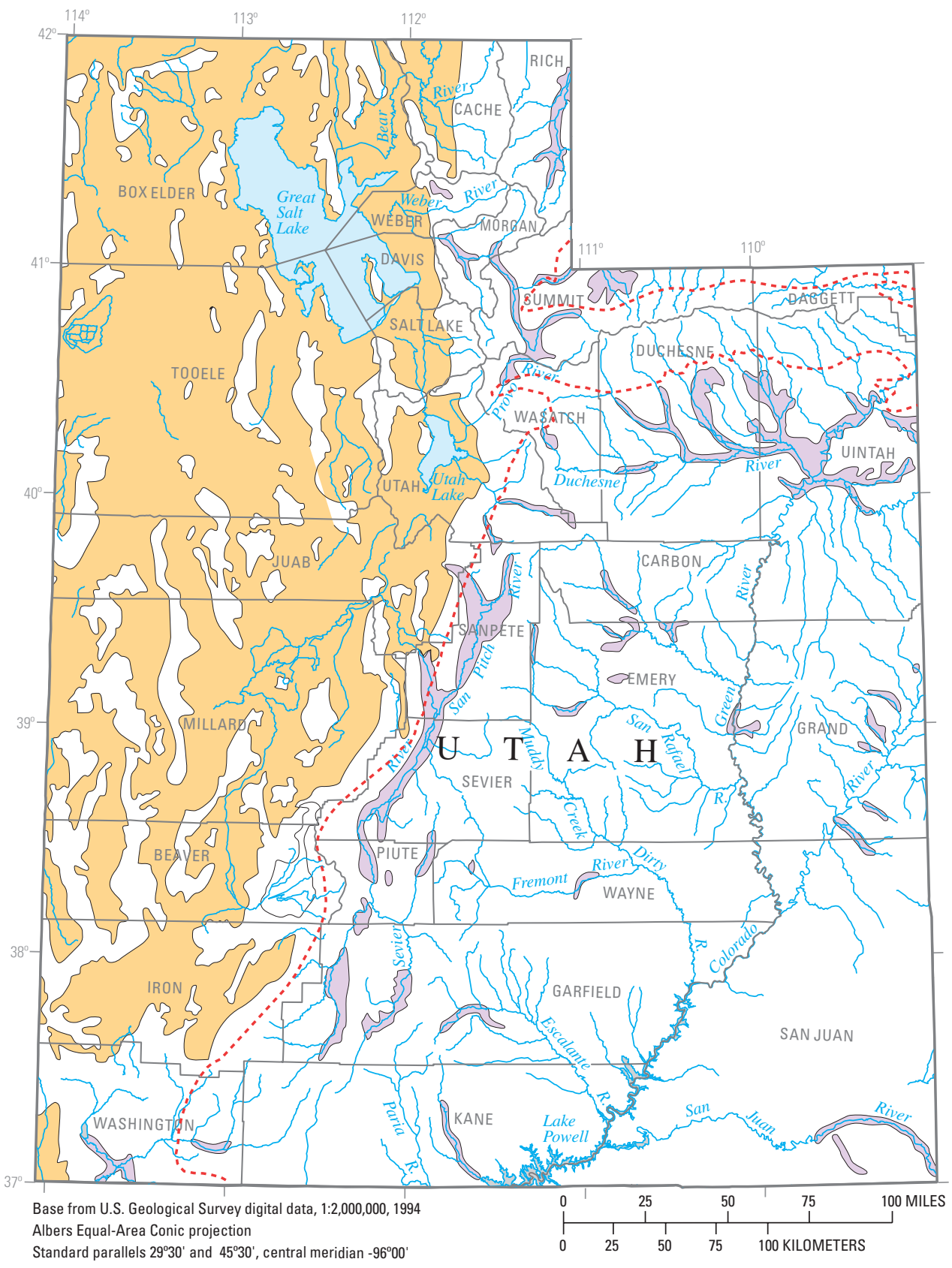

EXPLANATION

Extent of alluvial or eolian deposits

Mountainous area

Basin and range area

Colorado Plateaus aquifers

Figure 25. Extent of alluvial deposits in Utah where withdrawals from Alluvial aquifers were associated with stream-valley aquifers (source: Miller, 2000, fig. 18, p. C7). Withdrawals from stream-valley aquifers were identified from a subset of the mountainous area alluvial deposits, and also from small, unmapped stream-valley aquifers along the Bear and Weber Rivers. 
Alluvial aquifers in Utah, excluding withdrawals assigned to stream-valley aquifers, increased from 6.73 to $7.50 \mathrm{Mgal} / \mathrm{d}$ (tables 1 and 3), and total Basin and Range basin-fill aquifers withdrawals decreased from $679 \mathrm{Mgal} / \mathrm{d}$ to $678 \mathrm{Mgal} / \mathrm{d}$ (table 1). No withdrawals from Other aquifers in Utah in 2000 were attributed to stream-valley aquifers, but withdrawals generally were attributed to unspecified bedrock units or basin-fill alluvial aquifers (table 4).

\section{West Virginia}

In 2000, total ground-water withdrawals for all categories of use in West Virginia were $90.9 \mathrm{Mgal} / \mathrm{d}$ (Hutson and others, 2004). About 56 percent (51.3 Mgal/d) of the withdrawals were for public-supply, self-supplied industrial, and irrigation uses, and were assigned to five principal and Other aquifers (Maupin and Barber, 2005) (appendix 2).
Withdrawals from Alluvial and Other aquifers were 23.2 Mgal/d and accounted for 45 percent of withdrawals from principal and Other aquifers for the three uses (appendix 2 ). Withdrawals were used mostly for public supply from Alluvial (20.8 Mgal/d) and Other (1.58 Mgal/d) aquifers (appendix 2).

About 99 percent $(21.3 \mathrm{Mgal} / \mathrm{d})$ of the withdrawals from Alluvial aquifers in West Virginia were attributed to stream-valley aquifers associated with the Ohio (21.2 Mgal/d), Kanawha (0.09 Mgal/d), Monongahela (0.03 Mgal/d), and Potomac (0.01 Mgal/d) Rivers (fig. 26, table 3). All withdrawals from Alluvial aquifers for public-supply (20.8 Mgal/d) were attributed to the Ohio stream-valley aquifer. Withdrawals of $0.16 \mathrm{Mgal} / \mathrm{d}$ from Alluvial aquifers could not be disaggregated and assigned to a specific aquifer or aquifer system (table 1). Withdrawals of $1.72 \mathrm{Mgal} / \mathrm{d}$ from Other aquifers (table 4) were not attributed to stream-valley aquifers, but

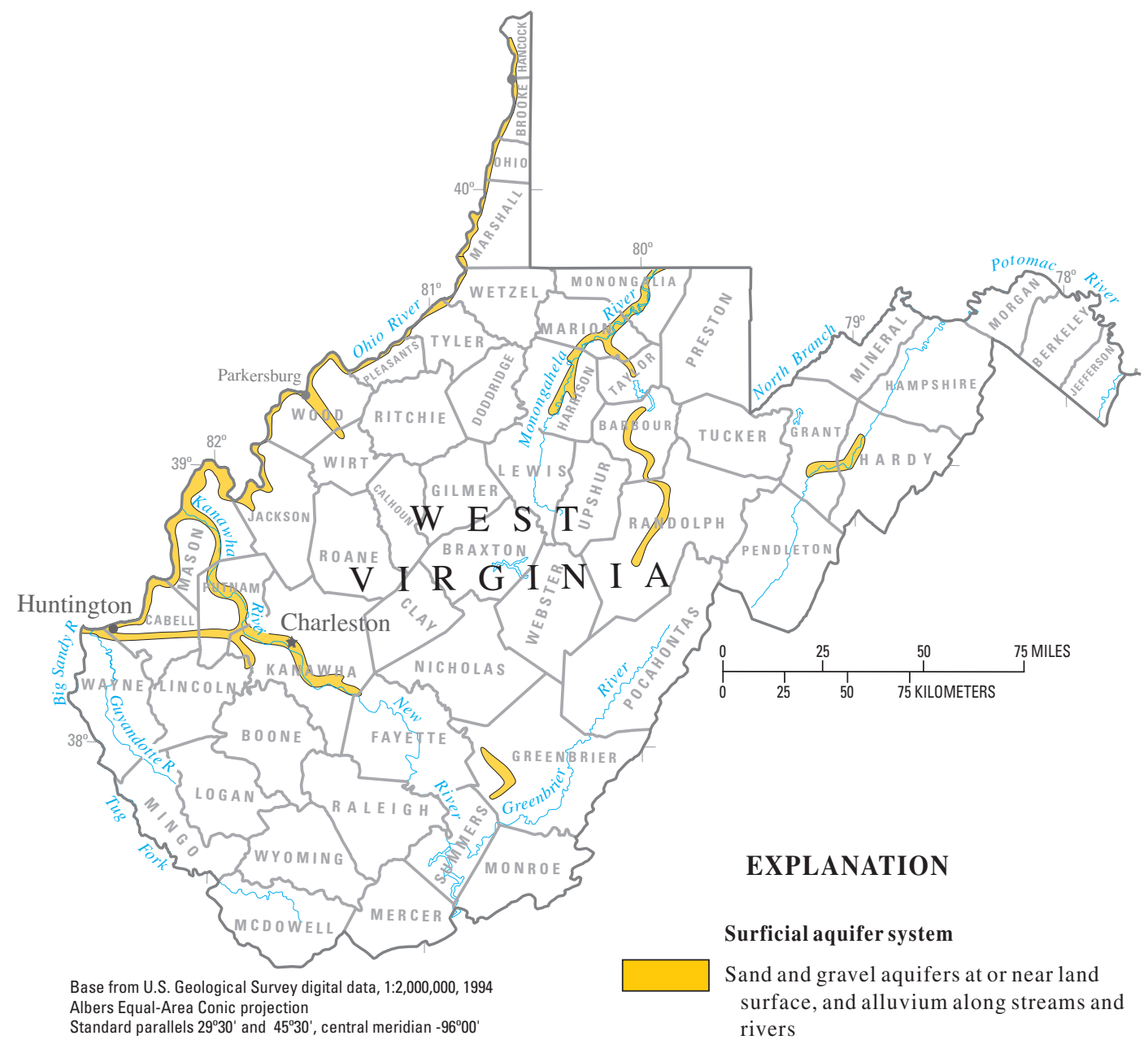

Figure 26. Extent of alluvial deposits in West Virginia where withdrawals from Alluvial aquifers were associated with stream-valley aquifers (source: Miller, 2000, fig. 6, p. L3). Withdrawals from stream-valley aquifers were identified from a subset of the alluvial deposits. 
were attributed to Appalachian Plateau aquifers along the eastern side of the State and to unnamed aquifers in areas labeled, "not a principal aquifer" in the atlas (Trapp and Horn, 1997).

\section{Wyoming}

In 2000, total ground-water withdrawals for all categories of use in Wyoming were about $541 \mathrm{Mgal} / \mathrm{d}$ (Hutson and others, 2004). About 88 percent (475 Mgal/d) of the withdrawals were for public-supply, self-supplied industrial, and irrigation uses, and were assigned to six principal and Other aquifers (Maupin and Barber, 2005) (appendix 2). Withdrawals from Alluvial aquifers accounted for 14 percent $(67.1 \mathrm{Mgal} / \mathrm{d})$ of the withdrawals from principal and Other aquifers in Wyoming. Withdrawals from the Alluvial aquifers were mostly for irriga- tion (50.4 Mgal/d), public-supply (15.7 Mgal/d), and self-supplied industrial (1.02 Mgal/d) uses. Withdrawals (3.30 Mgal/d) from Other aquifers accounted for less than 1 percent of the total principal and Other aquifer withdrawals, and were used mostly for irrigation (2.42 Mgal/d) (appendix 2).

About 14 percent $(9.59 \mathrm{Mgal} / \mathrm{d})$ of withdrawals from Alluvial aquifers were disaggregated to stream-valley aquifers associated with the Niobrara River (5.77 Mgal/d), Sand Creek (2.67 Mgal/d), and Belle Fourche River (1.15 Mgal/d) (fig. 27, table 3). The withdrawals were used mostly for irrigation $(9.58 \mathrm{Mgal} / \mathrm{d})$. Withdrawals of $57.5 \mathrm{Mgal} / \mathrm{d}$ from Alluvial aquifers could not be disaggregated and assigned to a specific aquifer or aquifer system (tables 1 and 3). No withdrawals from Other aquifers were attributed to stream-valley aquifers.

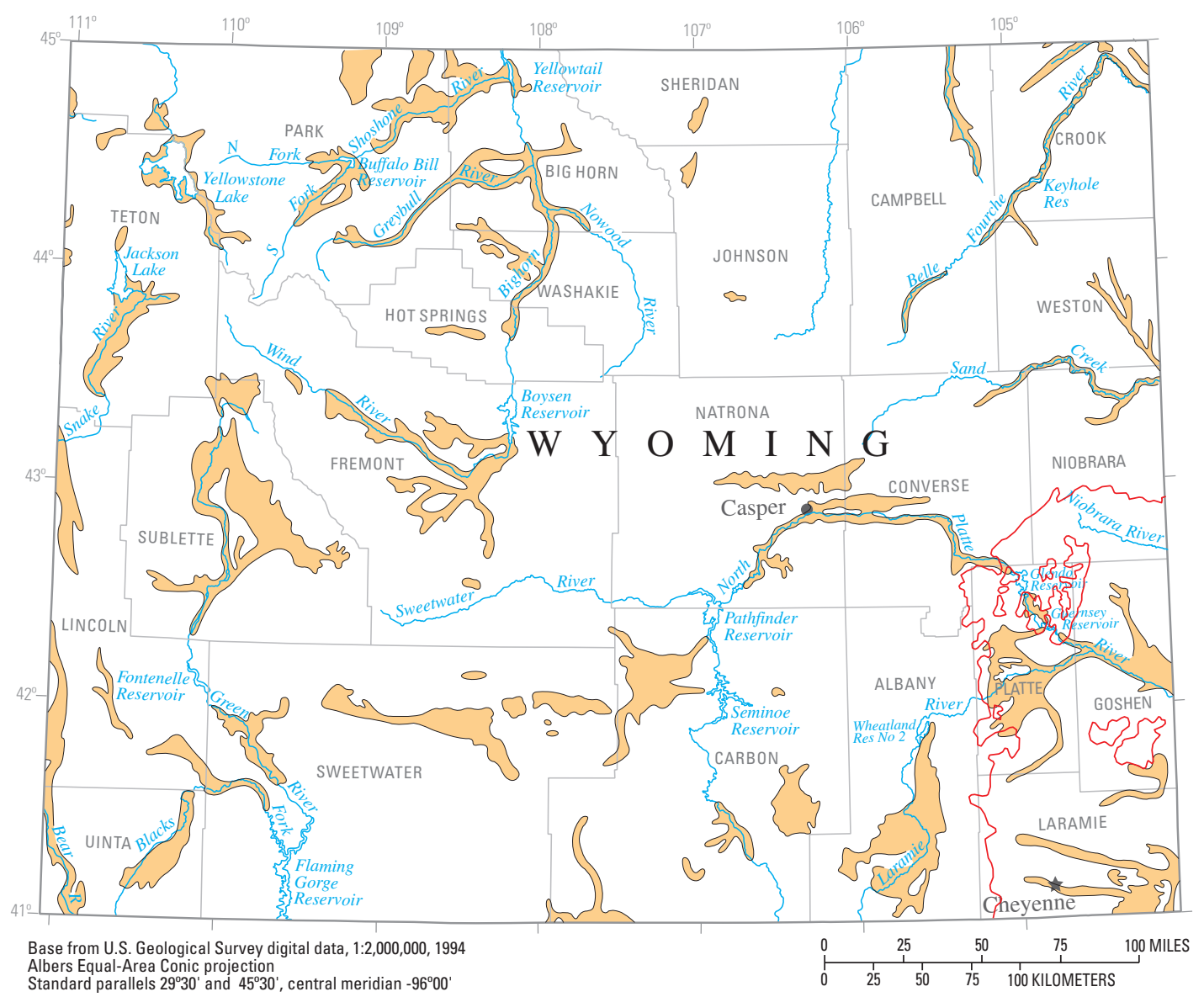

EXPLANATION

Stream-valley alluvium or basin fill

Extent of High Plains aquifer in Wyoming

Figure 27. Extent of stream-valley alluvium and basin-fill deposits in Wyoming where withdrawals from Alluvial aquifers were associated with stream-valley aquifers (source: Miller, 2000, fig. 6, p. 13). Withdrawals from stream-valley aquifers were identified from a subset of the alluvial deposits along Sand Creek and the Belle Fourche Rivers and from unmapped sediments along the Niobrara River. (See fig. 1 for full extent of the High Plains aquifer.) 


\section{Water-Resources Regions}

The 21 water-resources regions in the United States are geographic areas (hydrologic areas based on surface topography) that contain either the drainage area of a major river, such as the Missouri region, or the combined drainage areas of a series of rivers, such as the Texas-Gulf Region, which includes a number of rivers draining into the Gulf of Mexico (fig. 28) (Seaber and others, 1987). The regions were defined to provide a standardized base for use by water-resources organizations in locating, storing, retrieving, and exchanging hydrologic data.

Analysis of withdrawals from Alluvial, selected principal, and Other aquifers assigned 1,560 Mgal/d to stream-valley aquifers associated with major rivers, creeks, and areas where multiple streams are present. Stream-valley aquifer withdrawals were identified in eight water-resources regions (table 5).

\section{Arkansas-White-Red Region}

Withdrawals of $532 \mathrm{Mgal} / \mathrm{d}$ were assigned to streamvalley aquifers associated with 10 major rivers (table 5) in five states in the Arkansas-White-Red Region. Withdrawals from stream-valley aquifers associated with the Arkansas River in Arkansas, Colorado, Kansas, and Oklahoma accounted for about 74 percent (395 Mgal/d) of withdrawals from streamvalley aquifers in the region. About 19 percent $(100 \mathrm{Mgal} / \mathrm{d})$ of the withdrawals were from stream-valley aquifers associated with rivers in Oklahoma. About 80 percent (423 Mgal/d) of the withdrawals from stream-valley aquifers in the region were used for irrigation (table 5).

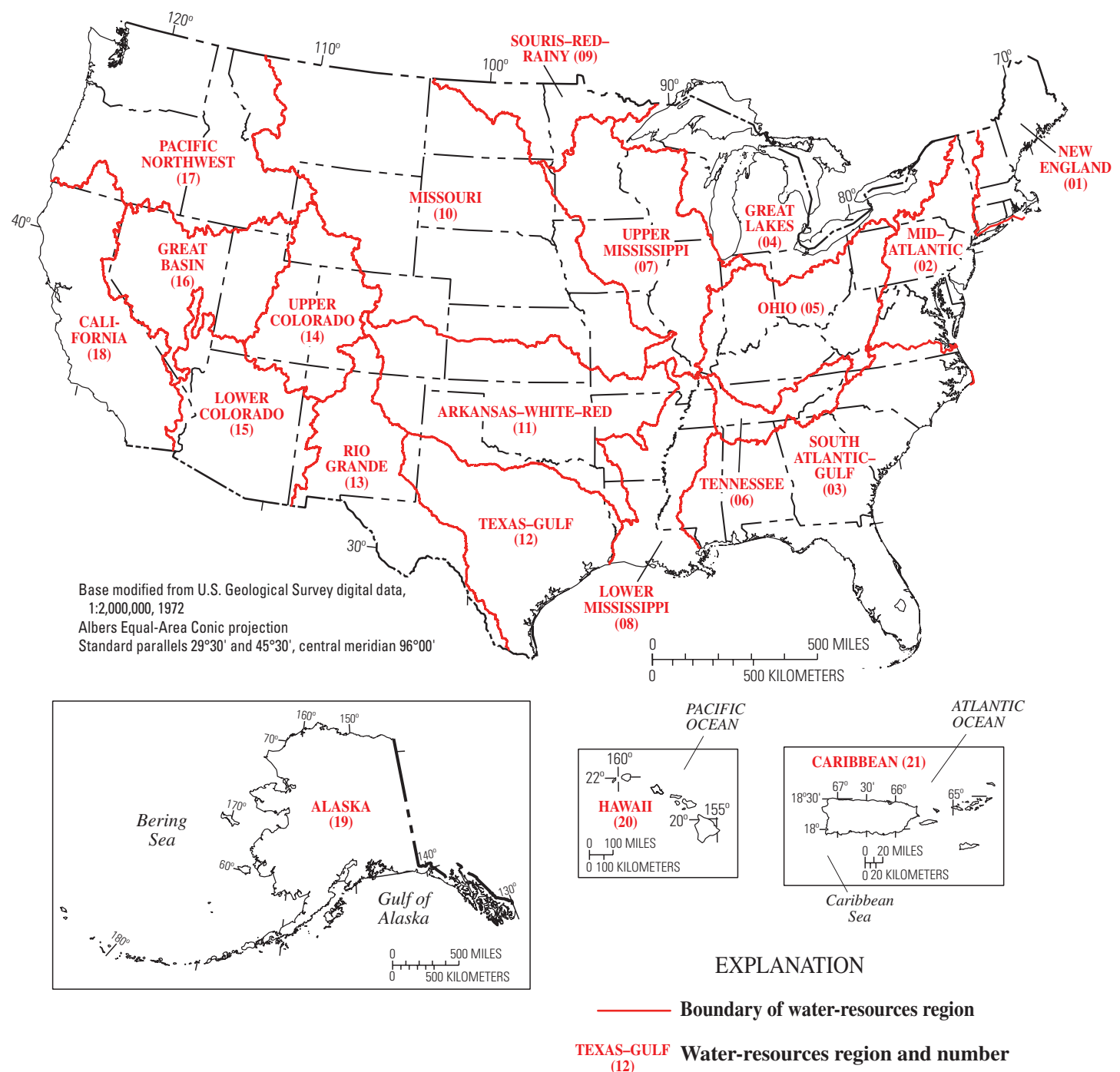

Figure 28. Water-resources regions of the United States (Seaber and others, 1987). 
Table 5. Estimated withdrawals from stream-valley aquifers associated with major rivers, creeks, and areas by waterresources region, 2000.

[Values are rounded]

\begin{tabular}{|c|c|c|c|c|}
\hline \multirow{2}{*}{ Major river, creek, or area } & \multicolumn{4}{|c|}{ Withdrawals, in million gallons per day, by water-use category } \\
\hline & Irrigation & Public supply & Self-supplied industrial & Total \\
\hline \multicolumn{5}{|c|}{ Arkansas-White-Red Region } \\
\hline Arkansas River & 328 & 44.6 & 22.1 & 395 \\
\hline Canadian River & 8.27 & 4.59 & .01 & 12.9 \\
\hline Cimarron River & 17.8 & 12.9 & .06 & 30.7 \\
\hline Neosho River & .21 & .33 & .01 & .55 \\
\hline North Canadian River & 12.4 & 11.4 & .44 & 24.3 \\
\hline Ouachita-Saline River & .05 & .14 & .02 & .21 \\
\hline Red River & 41.9 & 9.78 & .26 & 51.9 \\
\hline Verdigris River & .00 & .13 & .00 & .13 \\
\hline Walnut River & 8.90 & .57 & .05 & 9.52 \\
\hline Washita River & 5.43 & .95 & .00 & 6.38 \\
\hline Total & 423 & 85.4 & 22.9 & 532 \\
\hline \multicolumn{5}{|c|}{ Mid-Atlantic Region } \\
\hline Delaware River & .00 & .10 & .00 & .10 \\
\hline Potomac River & .00 & .00 & .01 & .01 \\
\hline Total & .00 & .10 & .01 & .11 \\
\hline \multicolumn{5}{|c|}{ Missouri Region } \\
\hline Bear Butte Creek & .08 & .00 & .00 & .08 \\
\hline Belle Fourche River & 1.16 & .00 & .00 & 1.16 \\
\hline Big Blue River & .31 & 2.91 & 1.67 & 4.89 \\
\hline Cheyenne River & .05 & 13.2 & .14 & 13.4 \\
\hline Kansas River & 3.01 & 1.53 & 3.04 & 7.58 \\
\hline Little Missouri River & .32 & .08 & .00 & .40 \\
\hline Marais des Cygnes River & .00 & .05 & .00 & .05 \\
\hline Missouri River & 1.30 & 47.4 & 2.34 & 51.0 \\
\hline Niobrara River & 5.77 & .00 & .00 & 5.77 \\
\hline Osage River & .33 & .07 & .00 & .40 \\
\hline Republican River & 64.3 & 9.40 & .10 & 73.8 \\
\hline Saline River & 2.74 & .55 & .00 & 3.29 \\
\hline Sand Creek & 2.66 & .00 & .01 & 2.67 \\
\hline Smoky Hill River & 21.2 & 8.56 & .02 & 29.8 \\
\hline Solomon River & 18.9 & 3.31 & .00 & 22.2 \\
\hline South Grand River & .21 & .19 & .00 & .40 \\
\hline South Platte River & 387 & 5.87 & 10.8 & 404 \\
\hline White River & .05 & .05 & .00 & .10 \\
\hline Yellowstone River & 5.20 & 1.54 & .10 & 6.84 \\
\hline Total & 515 & 94.7 & 18.2 & 628 \\
\hline \multicolumn{5}{|c|}{ Ohio Region } \\
\hline Allegheny River & .00 & 17.1 & 26.3 & 43.5 \\
\hline Beaver River & .00 & 1.13 & .30 & 1.43 \\
\hline Hocking River & .00 & 4.32 & .00 & 4.32 \\
\hline Kanawha River & .00 & .00 & .09 & .09 \\
\hline Lower East Fork White River & .00 & 1.09 & .10 & 1.19 \\
\hline Miscellaneous rivers and creeks & .00 & .25 & .00 & .25 \\
\hline Monongahela River & .00 & .91 & 2.47 & 3.38 \\
\hline Muskingum River & .00 & 15.7 & 1.98 & 17.7 \\
\hline Ohio River & 2.61 & 130 & 88.4 & 221 \\
\hline Sandy Creek & .00 & 1.32 & .28 & 1.60 \\
\hline Scioto River & .00 & 6.60 & .01 & 6.61 \\
\hline Tuscarawas River & .12 & 17.4 & 14.2 & 31.7 \\
\hline Wabash River & .37 & .43 & .00 & .80 \\
\hline Walhonding River & .00 & 8.18 & .00 & 8.18 \\
\hline Total & 3.1 & 205 & 134 & 342 \\
\hline
\end{tabular}


Table 5. Estimated withdrawals from stream-valley aquifers associated with major rivers, creeks, and areas by waterresources region, 2000-Continued.

[Values are rounded]

\begin{tabular}{|c|c|c|c|c|}
\hline \multirow{2}{*}{ Major river, creek, or area } & \multicolumn{4}{|c|}{ Withdrawals, in million gallons per day, by water-use category } \\
\hline & Irrigation & Public supply & Self-supplied industrial & Total \\
\hline \multicolumn{5}{|c|}{ Tennessee Region } \\
\hline Tennessee River & 0.00 & 2.30 & 0.00 & 2.30 \\
\hline \multicolumn{5}{|c|}{ Texas-Gulf Region } \\
\hline Brazos River & 12.6 & .01 & .00 & 12.6 \\
\hline \multicolumn{5}{|c|}{ Upper Colorado Region } \\
\hline Bear River & .89 & .00 & .00 & .89 \\
\hline Duchesne River & .89 & .00 & .00 & .89 \\
\hline Fremont River & 3.12 & .00 & .00 & 3.12 \\
\hline Provo River & .89 & .53 & .00 & 1.42 \\
\hline San Pitch River & .00 & .22 & .47 & .69 \\
\hline Sevier River & 14.0 & 3.30 & .00 & 17.3 \\
\hline $\begin{array}{l}\text { Miscellaneous rivers in mountain- } \\
\text { ous areas }\end{array}$ & 9.85 & 3.86 & .94 & 14.7 \\
\hline Weber River & .09 & .43 & .00 & .52 \\
\hline Total & 29.7 & 8.34 & 1.41 & 39.5 \\
\hline \multicolumn{5}{|c|}{ Upper Mississippi Region } \\
\hline Mississippi River below St. Louis & .41 & 4.02 & .29 & 4.72 \\
\hline Grand Total & 984 & 400 & 177 & 1,560 \\
\hline
\end{tabular}

\section{Mid-Atlantic Region}

Withdrawals of $0.11 \mathrm{Mgal} / \mathrm{d}$ were assigned to streamvalley aquifers in the Mid-Atlantic Region (table 5). Withdrawals from stream-valley aquifers were associated with the Delaware River $(0.10 \mathrm{Mgal} / \mathrm{d})$ in Pennsylvania and the Potomac River (0.01 Mgal/d) in West Virginia. About 91 percent $(0.10 \mathrm{Mgal} / \mathrm{d})$ of the withdrawals were used for public-supply uses (table 5).

\section{Missouri Region}

Withdrawals of $628 \mathrm{Mgal} / \mathrm{d}$ were assigned to streamvalley aquifers associated with 20 rivers or creeks (table 5) in seven states in the Missouri Region. Withdrawals from stream-valley aquifers associated with the South Platte River in Colorado were $404 \mathrm{Mgal} / \mathrm{d}$ and accounted for about 64 percent of withdrawals from stream-valley aquifers in the region. About 82 percent $(515 \mathrm{Mgal} / \mathrm{d})$ of the withdrawals were used for irrigation (table 5).

\section{Ohio Region}

Withdrawals of $342 \mathrm{Mgal} / \mathrm{d}$ were assigned to streamvalley aquifers associated with 13 rivers and creeks (table 5) and a group of three rivers and creeks (miscellaneous rivers and creeks) in seven states in the Ohio Region. Withdrawals from stream-valley aquifers associated with the Ohio River in six states accounted for about 65 percent $(221 \mathrm{Mgal} / \mathrm{d})$ of withdrawals from stream-valley aquifers in the region. About 59 percent $(202 \mathrm{Mgal} / \mathrm{d})$ of the withdrawals were from streamvalley aquifers in Kentucky and Ohio. About 60 percent (205 Mgal/d) of the withdrawals from stream-valley aquifers in the region were used for public supply (table 5).

\section{Tennessee Region}

Withdrawals of $2.30 \mathrm{Mgal} / \mathrm{d}$ were assigned to streamvalley aquifers (table 5) associated with the Tennessee River in the Tennessee Region. All of the withdrawals were for publicsupply uses in Tennessee.

\section{Texas-Gulf Region}

Withdrawals of $12.6 \mathrm{Mgal} / \mathrm{d}$ were assigned to streamvalley aquifers (table 5) associated with the Brazos River in the Texas-Gulf Region. Almost all of the withdrawals were for irrigation uses in Texas.

\section{Upper Colorado Region}

Withdrawals of $39.5 \mathrm{Mgal} / \mathrm{d}$ were assigned to streamvalley aquifers in the Upper Colorado Region (table 5). Only the states of Colorado and Utah have stream-valley aquifer withdrawals in this region. The stream-valley aquifers were associated with seven major rivers in Utah and miscellaneous rivers in mountainous areas in Colorado. Withdrawals 
from stream-valley aquifers associated with the Sevier River accounted for about 44 percent $(17.3 \mathrm{Mgal} / \mathrm{d})$ of withdrawals from stream-valley aquifers in the region. About 75 percent (29.7 Mgal/d) of the withdrawals from stream-valley aquifers in the region were used for irrigation (table 5).

\section{Upper Mississippi Region}

Withdrawals of $4.72 \mathrm{Mgal} / \mathrm{d}$ were assigned to streamvalley aquifers associated with the Mississippi River below St. Louis in Illinois and Missouri in the Upper Mississippi Region (table 5). About 85 percent (4.02 Mgal/d) of the withdrawals were for public-supply uses (table 5).

\section{Summary}

The U.S. Geological Survey National Water Use Information Program compiles estimates of fresh ground-water withdrawals in the United States on a 5-year interval. In the year-2000 compilation, withdrawals were reported from principal aquifers and aquifer systems, including two general aquifers-Alluvial and Other aquifers. Withdrawals from Alluvial and Other aquifers were the 10th and 11th largest within the ranking of total withdrawals from principal aquifers and aquifer systems. Further differentiation and identification of water-use data categorized by Alluvial and Other aquifers was needed to determine whether another potentially important group of aquifers - stream-valley aquifers-provides substantial amounts of water for public-supply, self-supplied industrial, and irrigation uses. In 2004, an investigation was initiated to estimate withdrawals from stream-valley aquifers. In addition to examining Alluvial and Other aquifers, the investigation examined selected principal aquifers where appropriate.

Stream-valley aquifers are alluvial aquifers located in the valleys of major streams and rivers. Stream-valley aquifers are long but narrow aquifers that are in direct hydraulic connection with associated streams; they have limited extent compared to most principal aquifers, but are important sources of ground water. Withdrawals from this widespread aquifer group were not specifically identified in the year-2000 compilation.

Based in large part on information published in U.S. Geological Survey reports, preliminary analysis of withdrawal data and hydrogeologic and surface-water information indicated areas in the United States where possible stream-valley aquifers were located. The report focused on 24 states and the Commonwealth of Puerto Rico. Withdrawals reported from Alluvial aquifers and (or) Other aquifers in 22 states and the Commonwealth of Puerto Rico were investigated. Two additional states_-Arkansas and New Jersey-were investigated because withdrawals reported from other principal aquifers in these two states may be from stream-valley aquifers.
States in the study area were selected by generally excluding areas that lie completely within the maximum extent of Quaternary continental glaciation, areas west of the Rocky Mountain/Colorado Plateau region, and areas coincident with the North Atlantic Coastal Plain aquifer systems, Basin and Range basin-fill aquifers, and Northern Rocky Mountains Intermontane Basins aquifer system. In these excluded areas, stream-valley aquifers and their withdrawals typically cannot be differentiated from other principal aquifers consisting of the same types of materials.

Twenty states were determined to have withdrawals from stream-valley aquifers. The results of the analysis indicate that stream-valley aquifer withdrawals (about $1,560 \mathrm{Mgal} / \mathrm{d}$ ) are comparable to withdrawals from the 10th most productive principal aquifers in the United States. Of the $1,560 \mathrm{Mgal} / \mathrm{d}$ of withdrawals attributed to stream-valley aquifers, 1,240 Mgal/d were disaggregated from Alluvial aquifers, $116 \mathrm{Mgal} / \mathrm{d}$ from $O$ ther aquifers, $150 \mathrm{Mgal} / \mathrm{d}$ from glacial sand and gravel aquifers, 28.1 Mgal/d from Pennsylvanian aquifers, and 24.9 Mgal/d from the Mississippi River Valley alluvial aquifer.

Five states, including Colorado (552 Mgal/d), Kansas (384 Mgal/d), Oklahoma (126 Mgal/d), Kentucky (102 Mgal/d), and Ohio (100 Mgal/d), accounted for 81 percent of estimated stream-valley aquifer withdrawals. Of the total withdrawals from stream-valley aquifers, about 63 percent (984 Mgal/d) were used for irrigation, 26 percent (400 Mgal/d) were used for public-supply, and 11 percent (177 Mgal/d) were for self-supplied industrial uses. The largest estimated water withdrawals were from stream-valley aquifers associated with the South Platte (404 Mgal/d), Arkansas (395 Mgal/d), and Ohio (221 Mgal/d) Rivers.

The estimates of stream-valley aquifer withdrawals presented in this report represent an approximation of the minimum rate of withdrawals from stream-valley aquifers in the United States; nevertheless, this estimate provides a quantitative assessment on their importance. As such, this estimate may be useful for researchers evaluating groundwater resources at regional and national scales.

\section{References Cited}

Agnew, A. F., Tipton, M.J., and Steece, F.V., 1962, South Dakota's ground water needs and supplies: South Dakota State Geological Survey, MI-04, accessed December 3, 2004, at URL http://jurassic2.sdgs.usd.edu/pubs/pdf/ MI-04\%20-\%2024\%20pages.pdf.

Bowman, J.A., and Collins, M.A., 1987, Impacts of irrigation and drought on Illinois ground-water resources: Illinois State Water Survey, Report of Investigation 109, 31 p.

Burden, C.B., 2001, Ground-water conditions in Utah, spring of 2001: Utah Department of Natural Resources, Division of Water Resources, Cooperative Investigations Report no. $42,120 \mathrm{p}$. 
Fenelon, J.M., Bobay, K.E., Greeman, T.K., Hoover, M.E., Cohen, D.A., Fowler, K.K., Woodfield, M.C., Doss, P.K., and Durbin, J.M., 1994, Hydrogeologic atlas of aquifers in Indiana: U.S. Geological Survey Water-Resources Investigations Report 92-4142, 197 p.

Heath, R.C., 1984, Ground-water regions of the United States: U.S. Geological Survey Water-Supply Paper 2242, 78 p.

Hutson, S.S., Barber, N.L., Kenny, J.F., Linsey, K.S., Lumia, D.S., and Maupin, M.A., 2004, Estimated use of water in the United States in 2000: U.S. Geological Survey Circular 1268, 46 p., accessed October 5, 2004, at URL http://water. usgs.gov/pubs/circ/2004/circ1268

Kenny, J.F., ed., 2004, Guidelines for preparation of state water-use estimates for 2000: U.S. Geological Survey Techniques and Methods 4-4A, 49 p., accessed February 9 , 2006, at URL http://pubs.water.usgs.gov/tm4a4/

Lapham, W.W., Hamilton, P.A., and Myers, D.N., 2005, National Water-Quality Assessment Program-Cycle II Regional Assessments of Aquifers: U.S. Geological Survey Fact Sheet 2005-3013, 4 p., accessed September 28, 2006, at URL http://pubs.usgs.gov/fs/2005/3013

Lloyd, O.B. Jr., and Lyke, W.L., 1995, Ground water atlas of the United States, Segment 10, Illinois, Indiana, Kentucky, Ohio, and Tennessee: U.S. Geological Survey Hydrologic Investigations Atlas 730-K, 30 p.

Maupin, M.A., and Barber, N.L., 2005, Estimated withdrawals from principal aquifers in the United States, 2000: U.S. Geological Survey Circular 1279, 46 p., accessed September 13, 2006, at URL http://pubs.usgs.gov/circ/2005/1279

Miller, J.A., ed., 2000, Ground water atlas of the United States: U.S. Geological Survey Hydrologic Investigations Atlas 730, $404 \mathrm{p}$.

Miller, J.A., and Appel, C.L., 1997, Ground water atlas of the United States, Segment 3, Kansas, Missouri, and Nebraska: U.S. Geological Survey Hydrologic Investigations Atlas 730-D, 24 p.

Miller, J.A., Whitehead, R.L., Gingerich, S.B., Oki, D.S., and Olcott, P.G., 1999, Ground water atlas of the United States, Segment 13, Alaska, Hawaii, Puerto Rico, and the U.S. Virgin Islands: U.S. Geological Survey Hydrologic Investigations Atlas 730-N, 36 p.

Molina-Rivera, W.L., 2005, Estimated water use in Puerto Rico, 2000: U.S. Geological Survey Open-File Report 2005-1201, 26 p., accessed September 13, 2006, at URL http://pubs.usgs.gov/of/2005/1201/

Nebraska Department of Economic Development, 2004, 2004 Nebraska Manufacturers Directory, accessed September 14, 2006, at URL http://pio.neded.org/manufacture/ index.htm
North Dakota State Water Commission, 2007, Reports and Publications: accessed December 5, 2007, at URL http://www.swc.state.nd.us/4dlink9/4dcgi/ GetSubCategoryRecord/Reports\%20and\%20Publications/ County\%20Ground\%20Water\%20Studies

Northern Arizona University, 1999, Arizona Regional Geology: accessed June 22, 2006, at URL http://dana.ucc.nau. edu/ are-p/road_map/eco/geology.html

Office of Management and Budget, 1987, Standard industrial classification manual: Washington D.C., Executive Office of the President, U.S. Government Printing Office, 64 p.

Ohio State University, 2008, Ohioline-Environment: College of Food, Agricultural, and Environmental Sciences, accessed January 7, 2008, at URL http://ohioline.osu.edu/ lines/ennr.html

Olcott, P.G., 1995, Ground water atlas of the United StatesSegment 12, Connecticut, Maine, Massachusetts, New Hampshire, New York, Rhode Island, and Vermont: U.S. Geological Survey Hydrologic Investigations Atlas 730-M, $28 \mathrm{p}$.

Renken, R.A., 1998, Ground water atlas of the United States, Segment 5, Arkansas, Louisiana, and Mississippi: U.S. Geological Survey Hydrologic Investigations Atlas 730-F, $28 \mathrm{p}$.

Robson, S.G., and Banta, E.R., 1995, Ground water atlas of the United States, Segment 2, Arizona, Colorado, New Mexico, and Utah: U.S. Geological Survey Hydrologic Investigations Atlas 730-C, 32 p.

Rosenshein, J.S., 1988, Chapter 21: Region 18, Alluvial valleys, in Back, William, Rosenshein, J.S., and Seaber, P.R., eds., Hydrogeology-The geology of North America, Volume O-2: Boulder, Colorado, The Geological Society of America, $524 \mathrm{p}$.

Ryder P.D., 1996, Ground water atlas of the United States, Segment 4, Oklahoma and Texas: U.S. Geological Survey Hydrologic Investigations Atlas 730-E, 30 p.

Seaber, P.R., Kapinos, F.P., and Knapp, G.L., 1987, Hydrologic unit maps: U.S. Geological Survey Water-Supply Paper 2294, 63 p., 1 pl. accessed October 12, 2006, at URL http://pubs.usgs.gov/wsp/wsp2294/pdf/wsp_2294.pdf

Trapp, Henry, Jr., and Horn, M.A., 1997, Ground water atlas of the United States, Segment 11, Delaware, Maryland, New Jersey, North Carolina, Pennsylvania, Virginia, and West Virginia: U.S. Geological Survey Hydrologic Investigations Atlas 730-L, 24 p.

U.S, Department of Agriculture, 1987, Photo gallery: Natural Resources Conservation Service, accessed January 14, 2008, at URL http://photogallery.nrcs.usda.gov/Detail.asp 
U.S, Department of Agriculture, 2002, Photo gallery: Natural Resources Conservation Service, accessed January 14, 2008, at URL http://photogallery.nrcs.usda.gov/Detail.asp

U.S. Geological Survey, 1998, National Water Information System (NWIS): U.S. Geological Survey Fact Sheet FS-027-98, 2 p., accessed February 6, 2007, at URL http://pubs.usgs.gov/fs/FS-027-98

U.S. Geological Survey, 2003, Principal aquifers of the 48 conterminous United States, Hawaii, Puerto Rico, and the U.S. Virgin Islands: U.S. Geological Survey 1:2,500,000 digital data, accessed February 7, 2007, at URL http://www. nationalatlas.gov/wallmaps.html\#aquifers
Utah Division of Water Rights, 2003, Utah water use program: accessed February 7, 2007, at URL http://waterrights.utah. gov/distinfo/wuse.asp

Utah Geological Survey, 2005, Utah Geological Survey: accessed September 22, 2006, at URL http://geology.utah. gov/

Whitehead, R.L., 1996, Ground water atlas of the United States, Segment 8, Montana, North Dakota, South Dakota and Wyoming: U.S. Geological Survey Hydrologic Investigations Atlas 730-I, 24 p. 
Blank Page 
Appendix 1 
Blank Page 


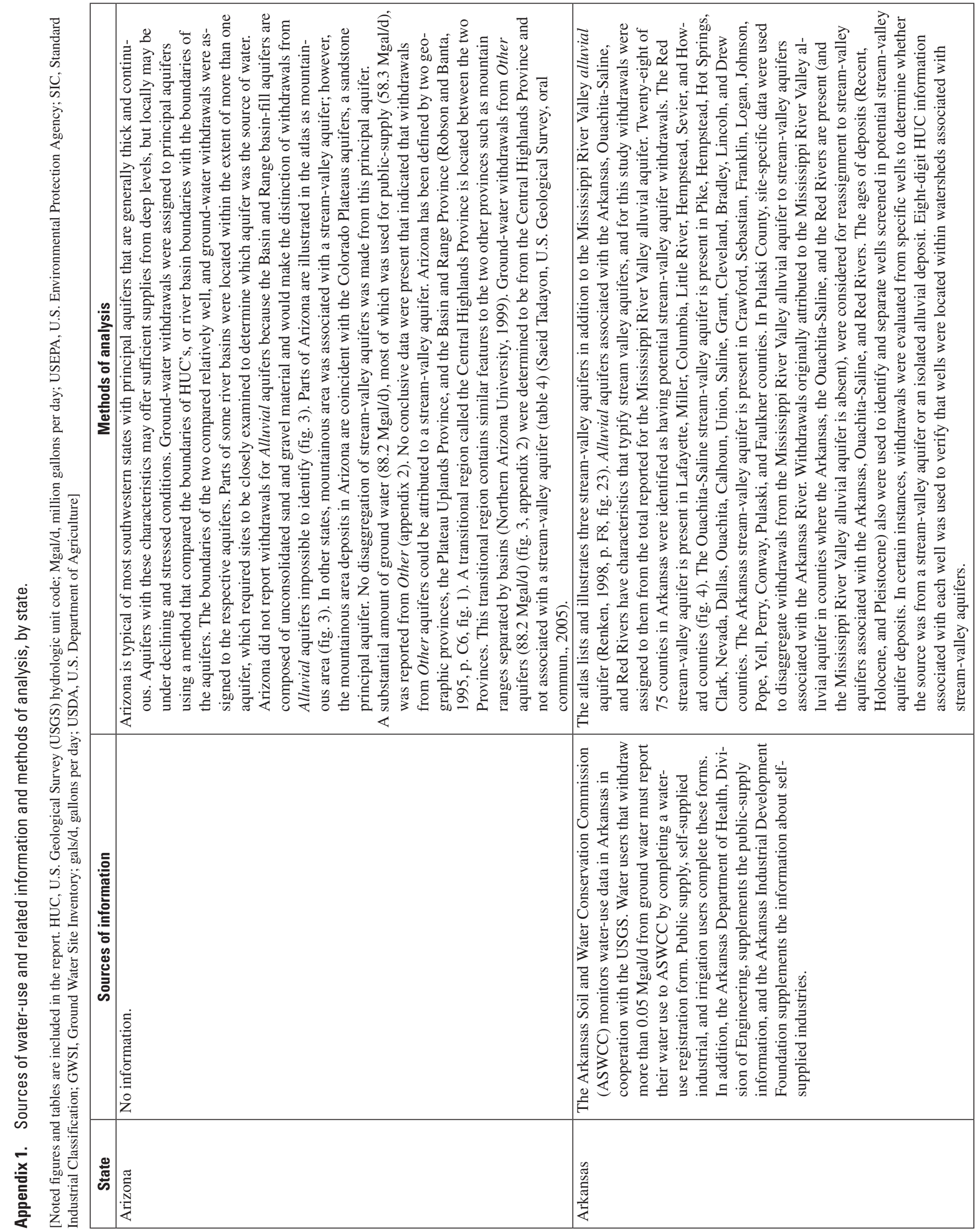




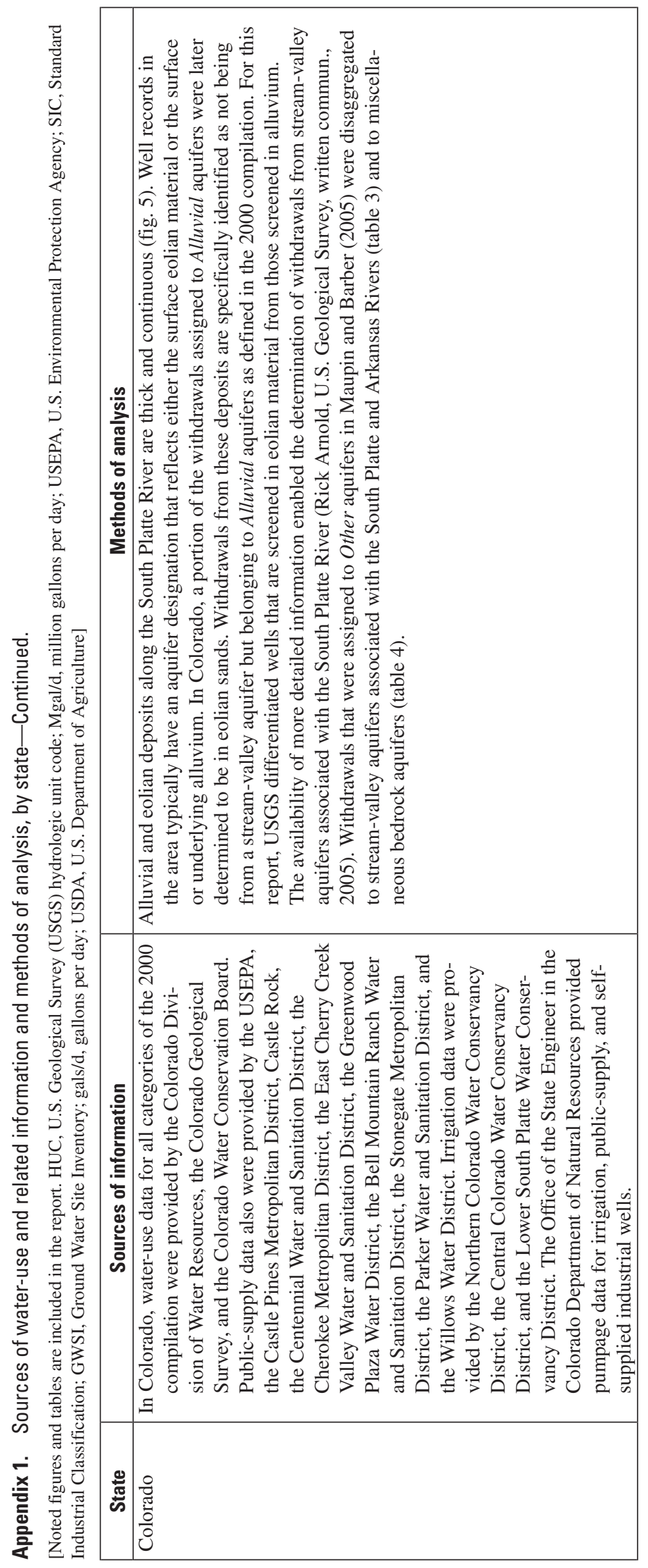




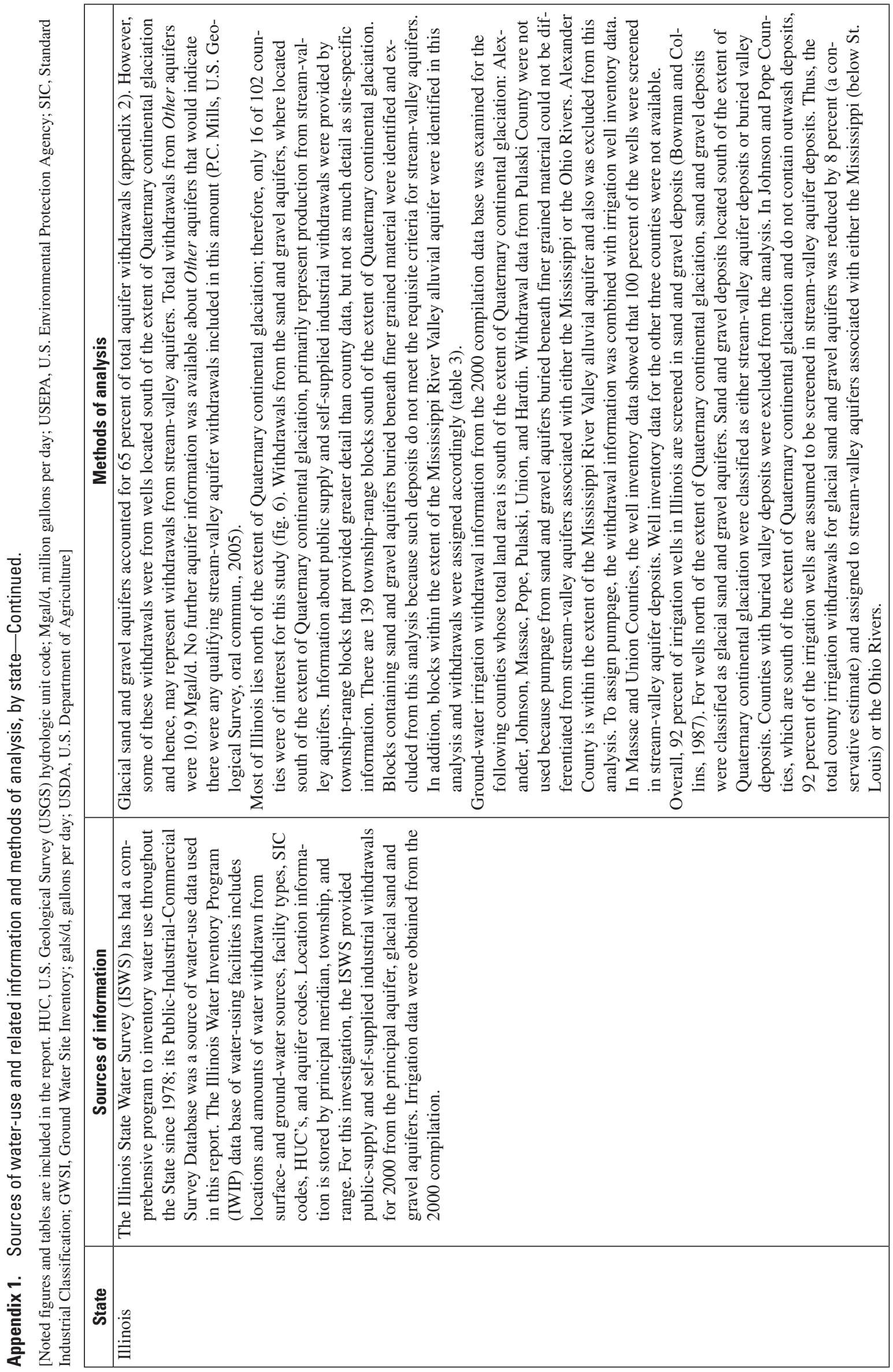




\begin{tabular}{|c|c|c|c|}
\hline 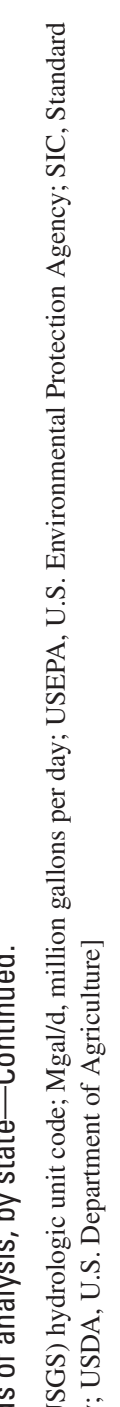 & & 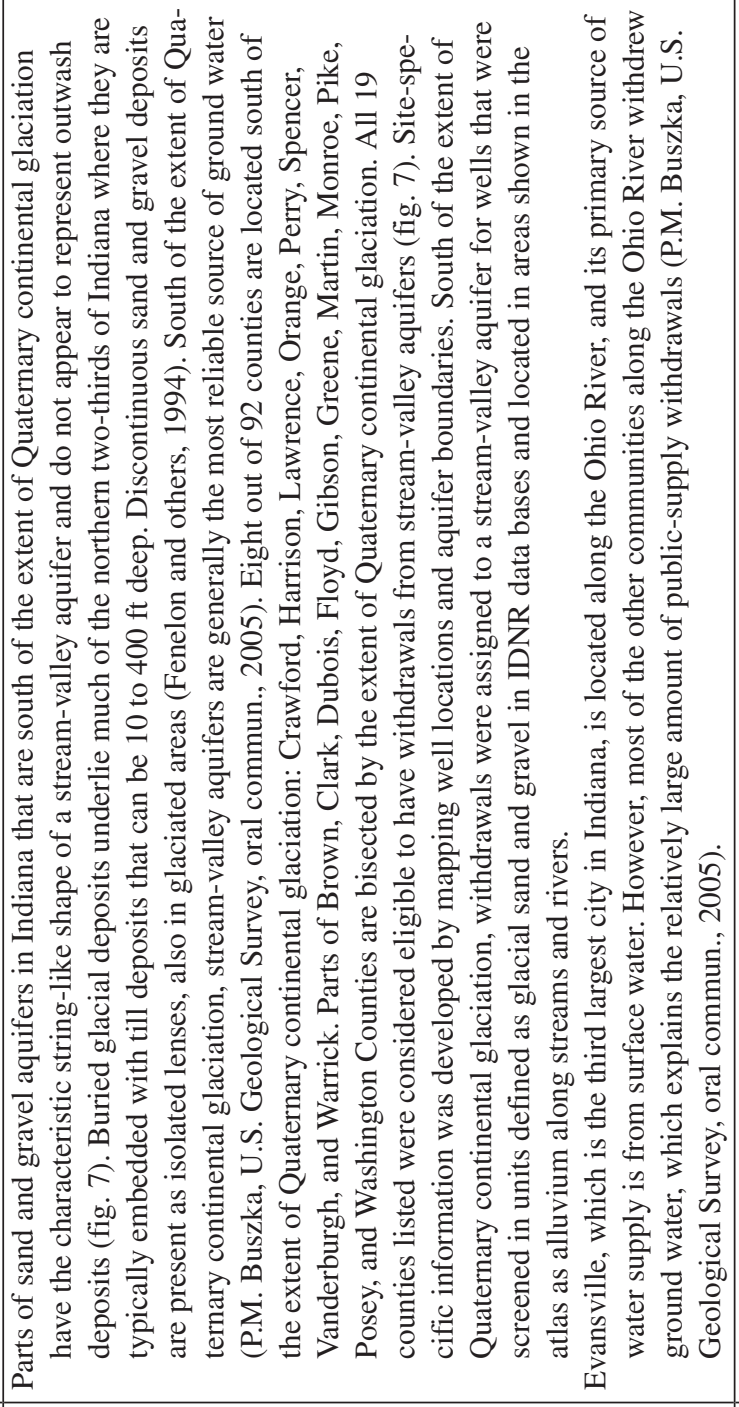 & 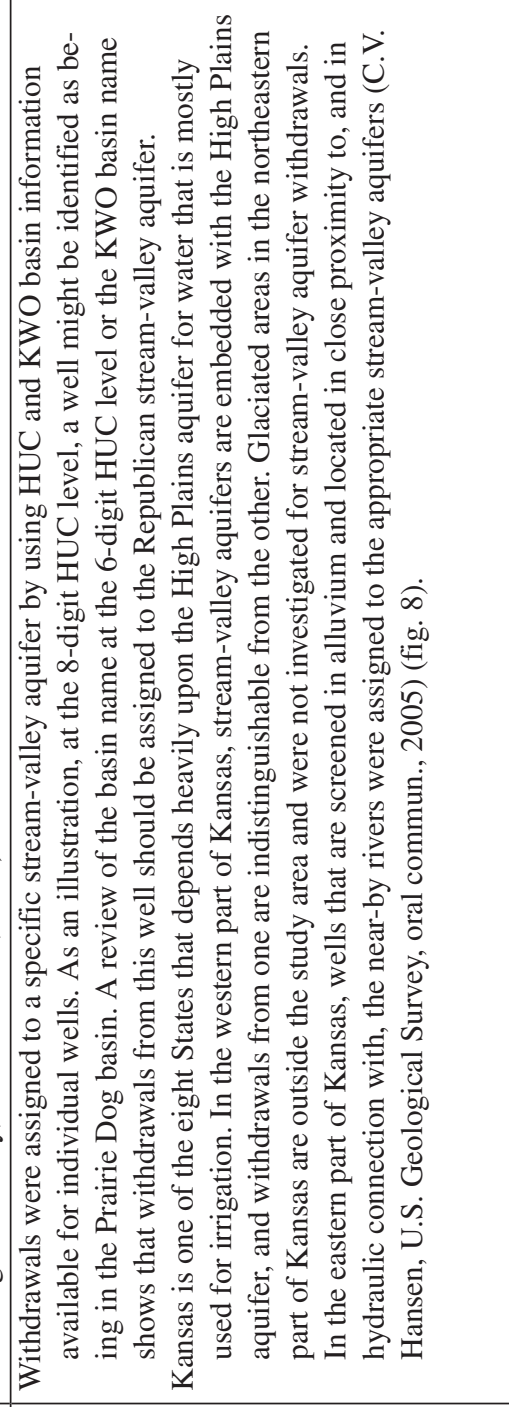 \\
\hline 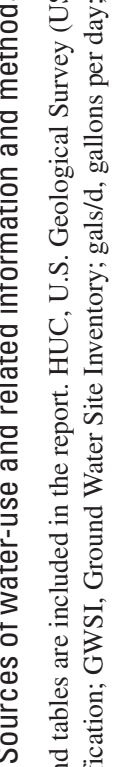 & & 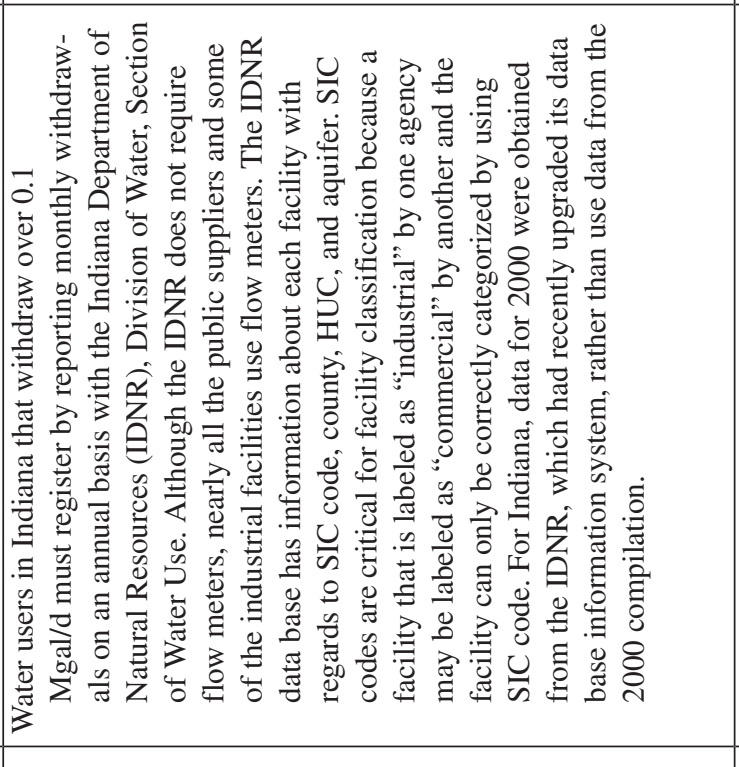 & 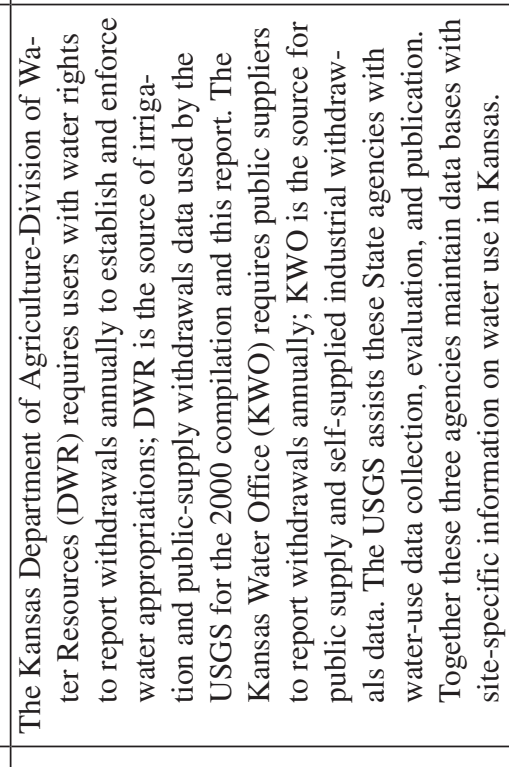 \\
\hline 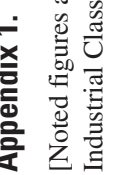 & & & \\
\hline
\end{tabular}




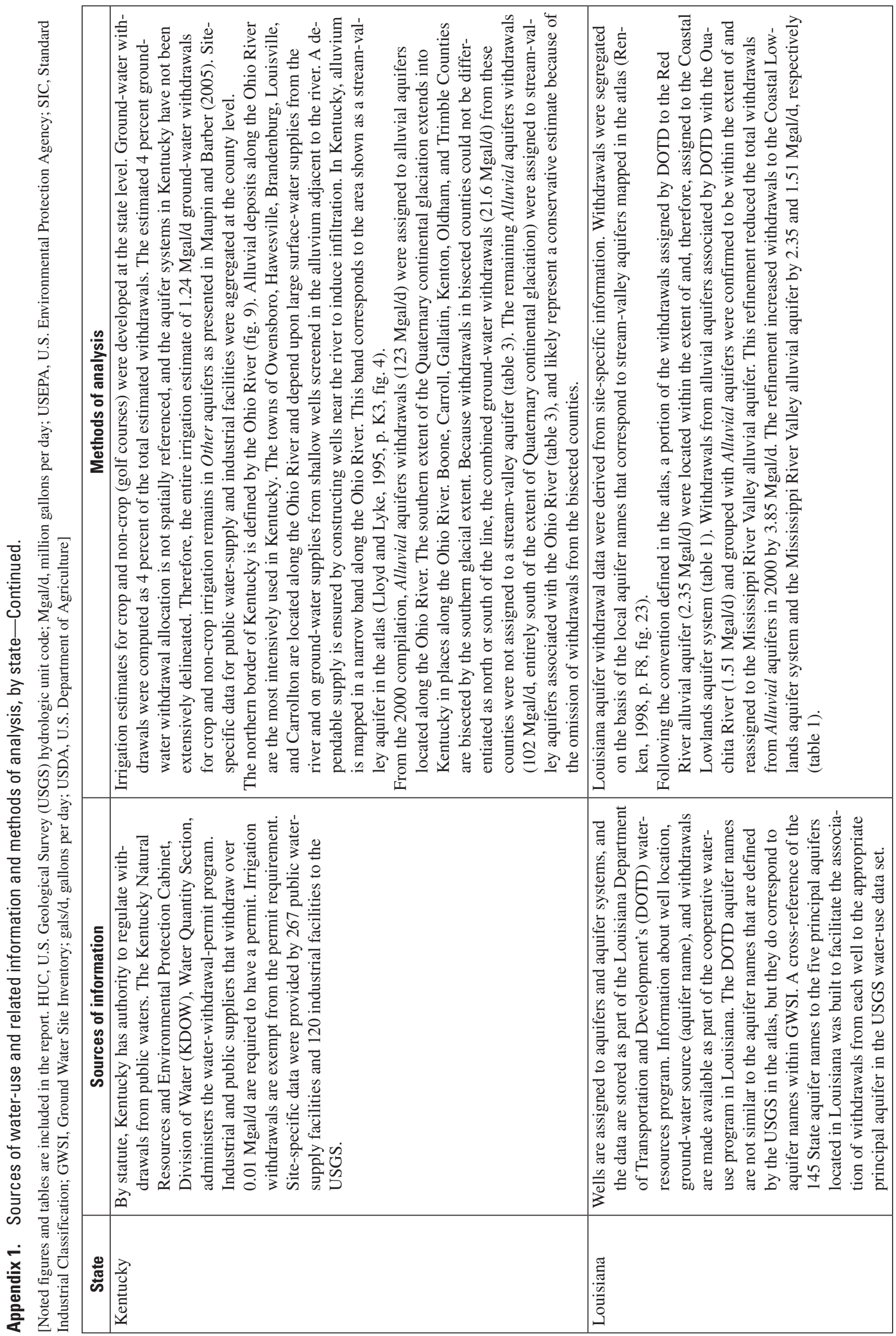




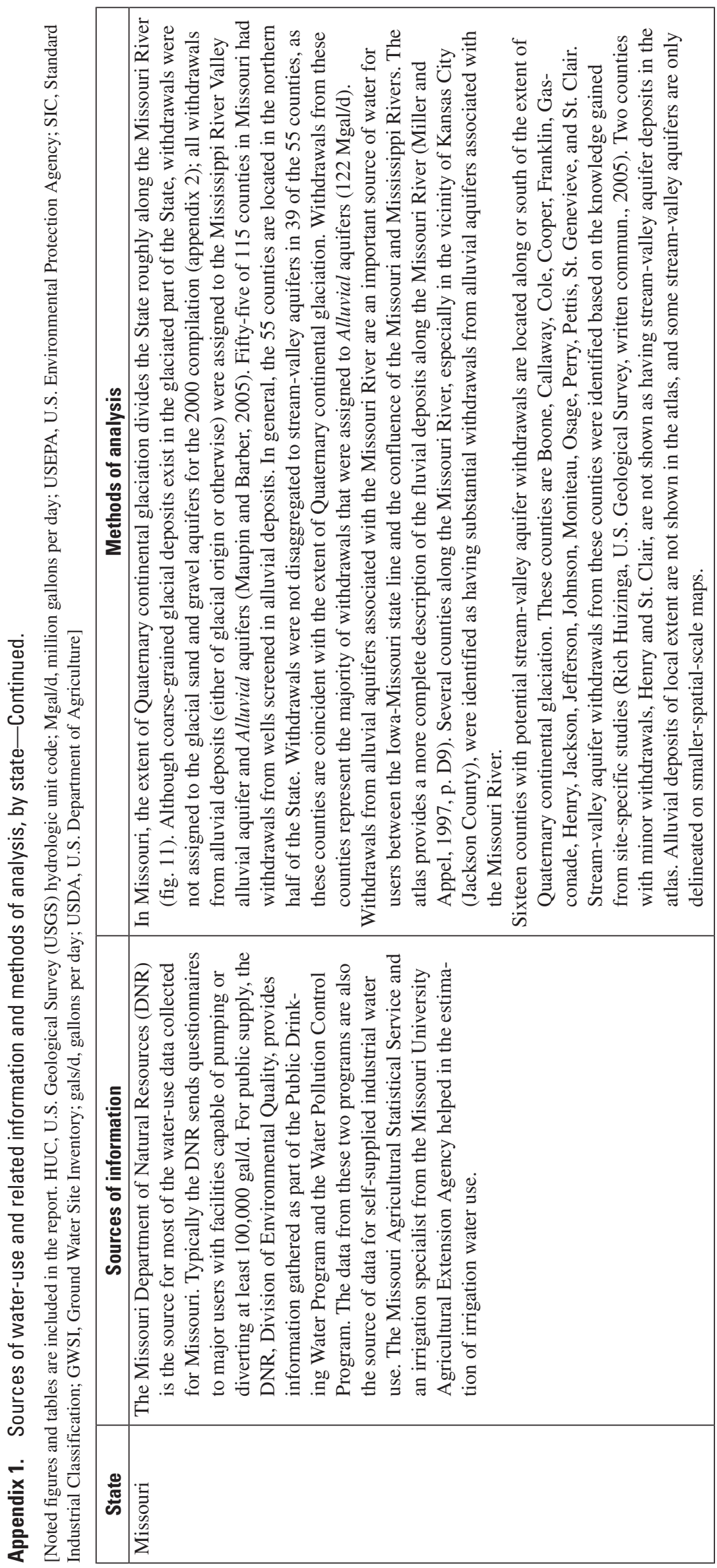




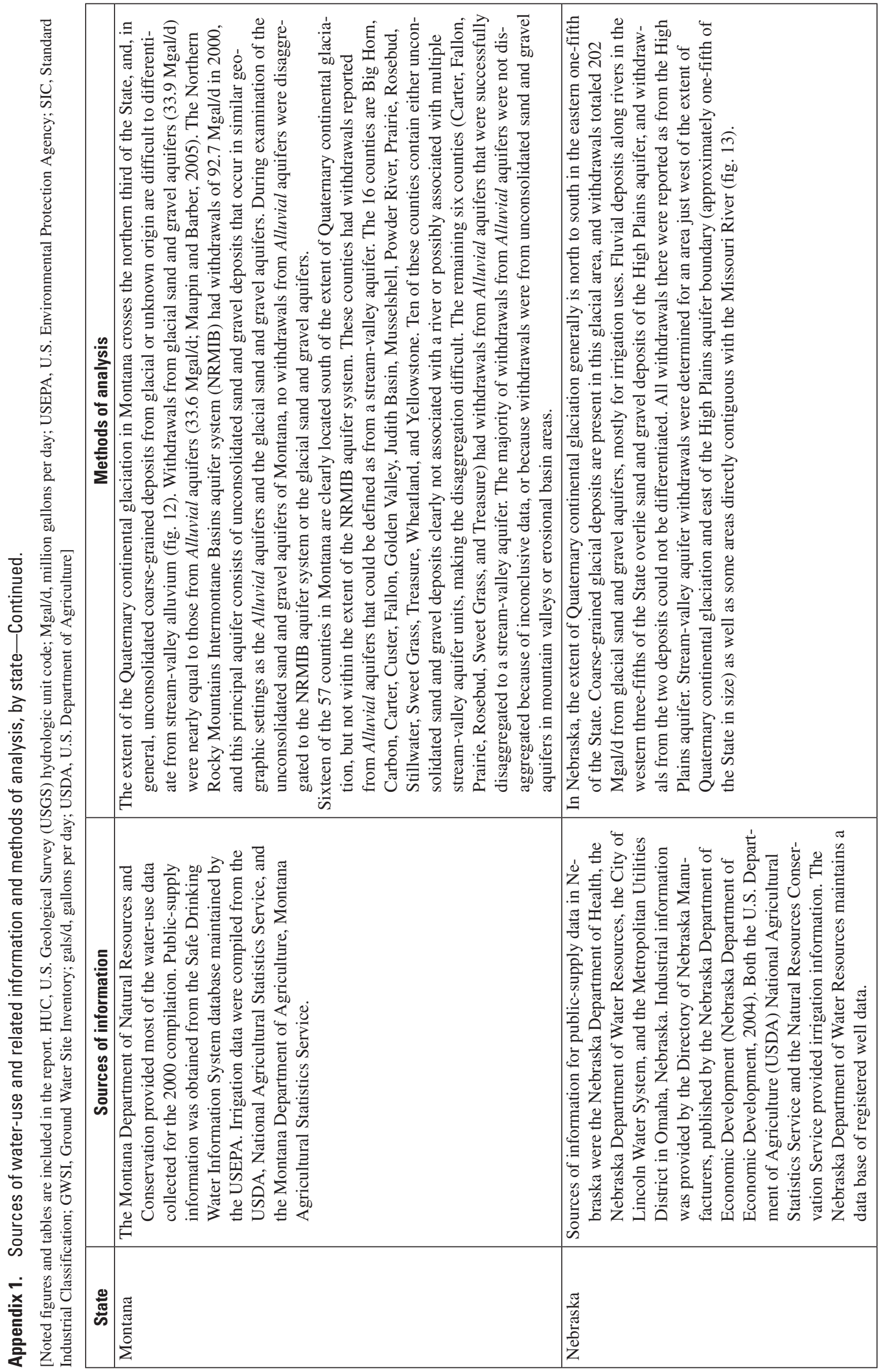




\begin{tabular}{|c|c|c|c|c|}
\hline 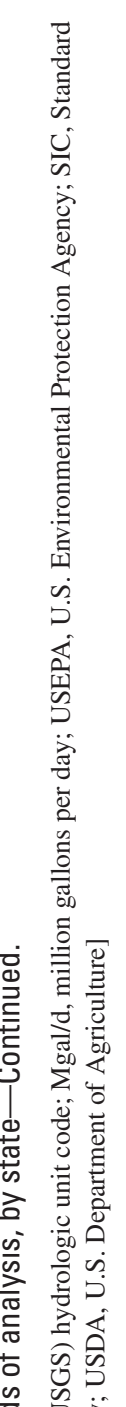 & & 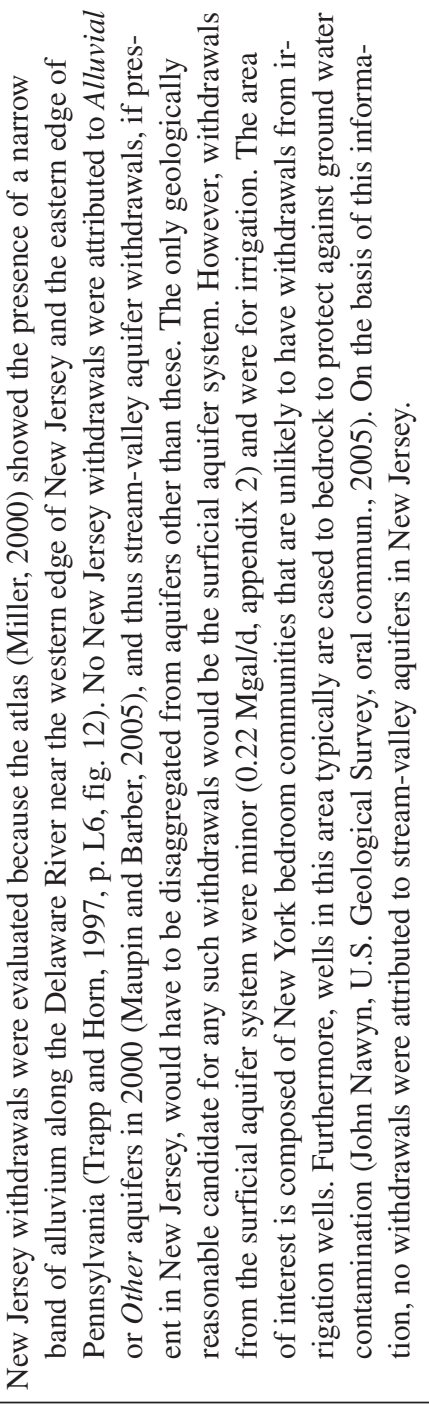 & 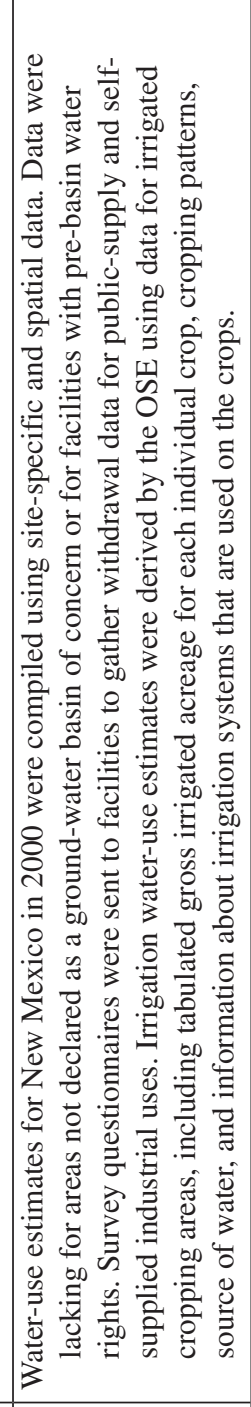 & 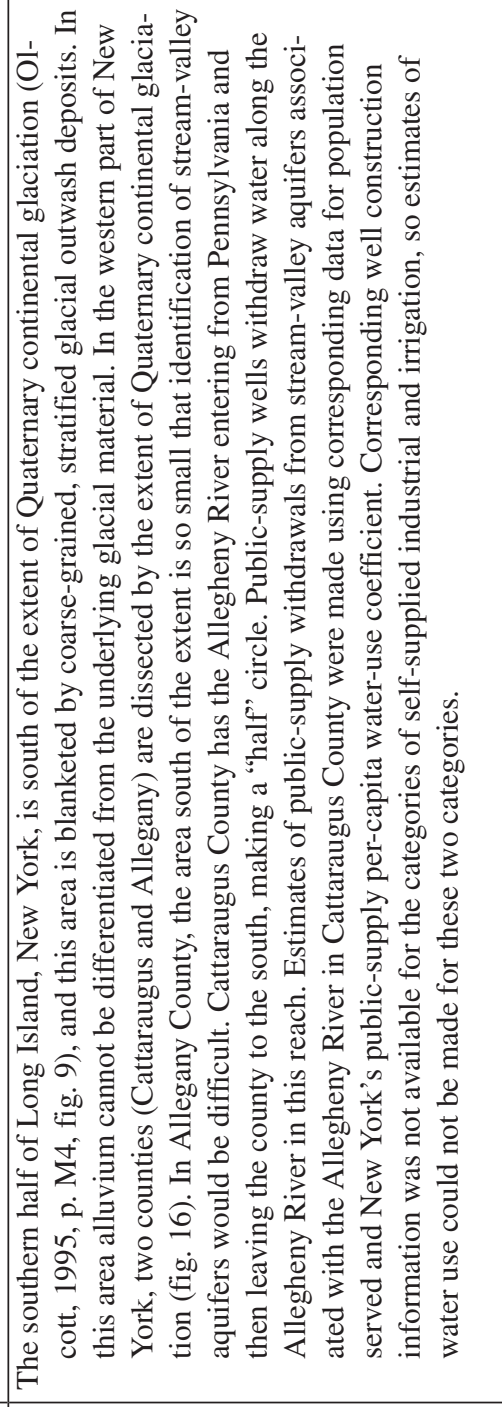 \\
\hline 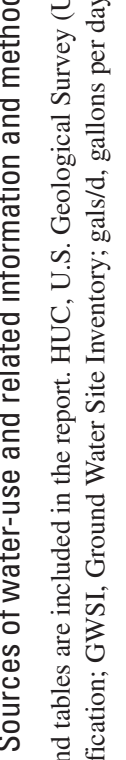 & 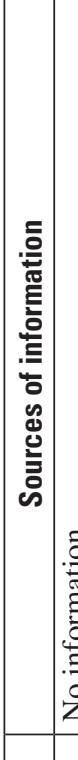 & & 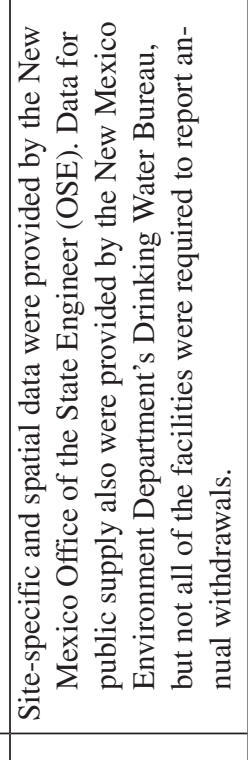 & 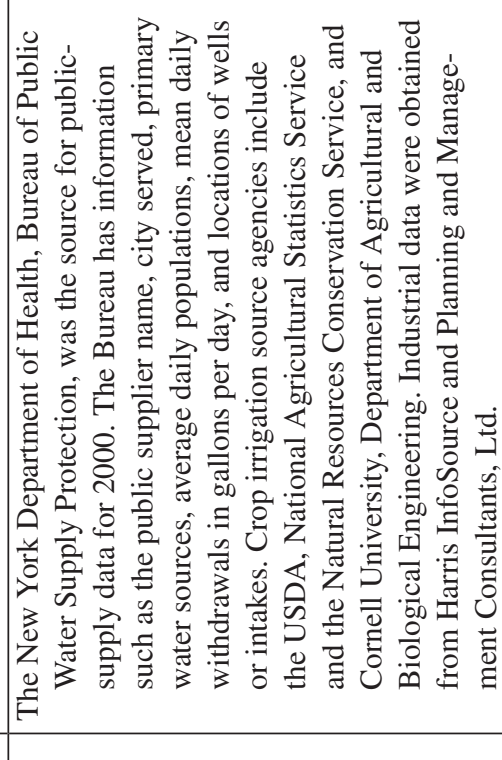 \\
\hline$\frac{\pi}{\tilde{U}}$ & & & 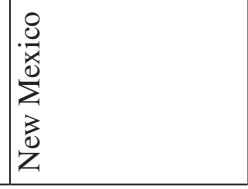 & \\
\hline
\end{tabular}




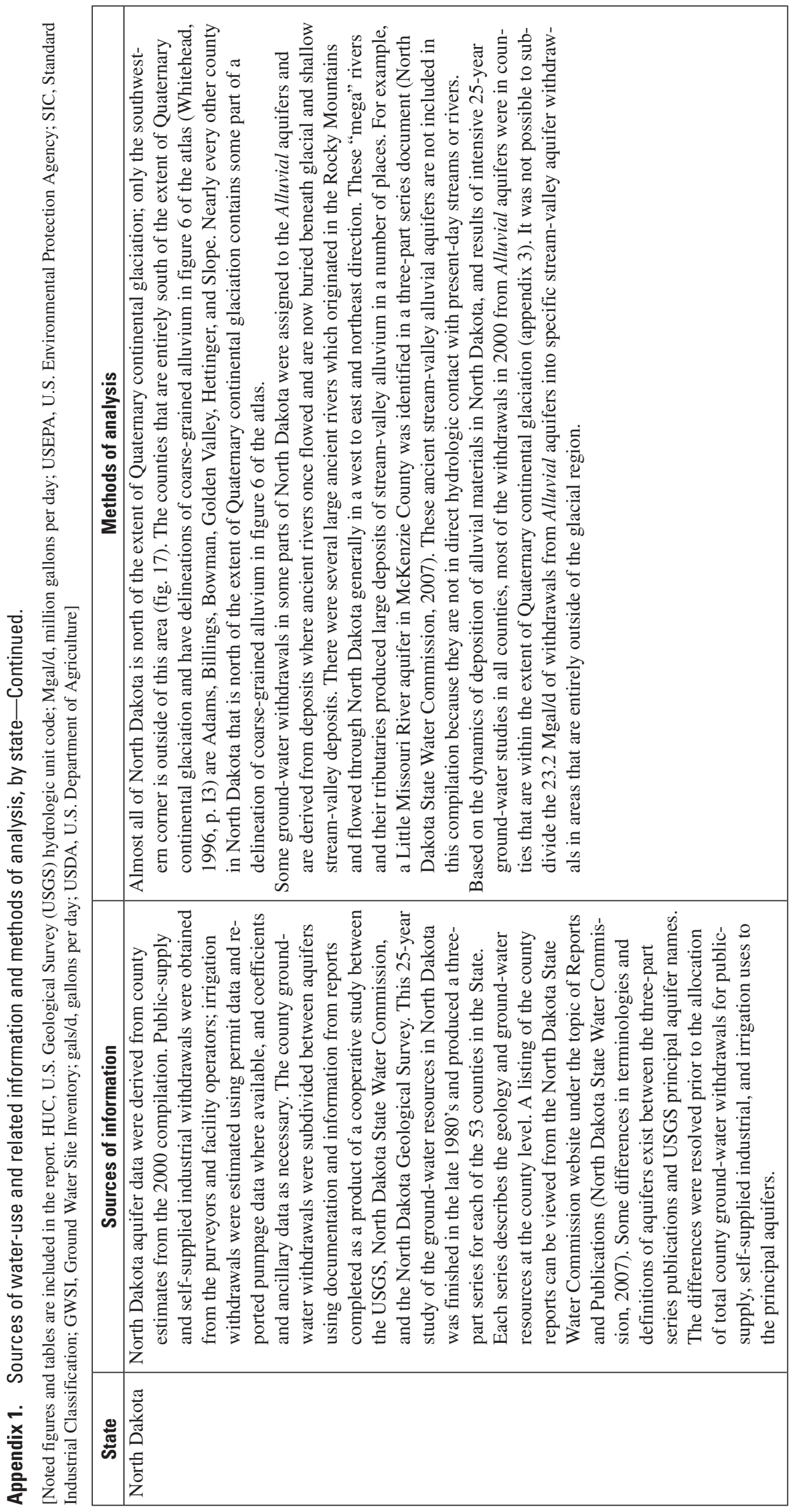




\begin{tabular}{|c|c|c|c|c|}
\hline 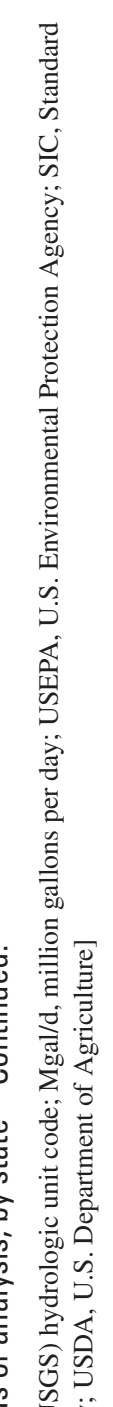 & & 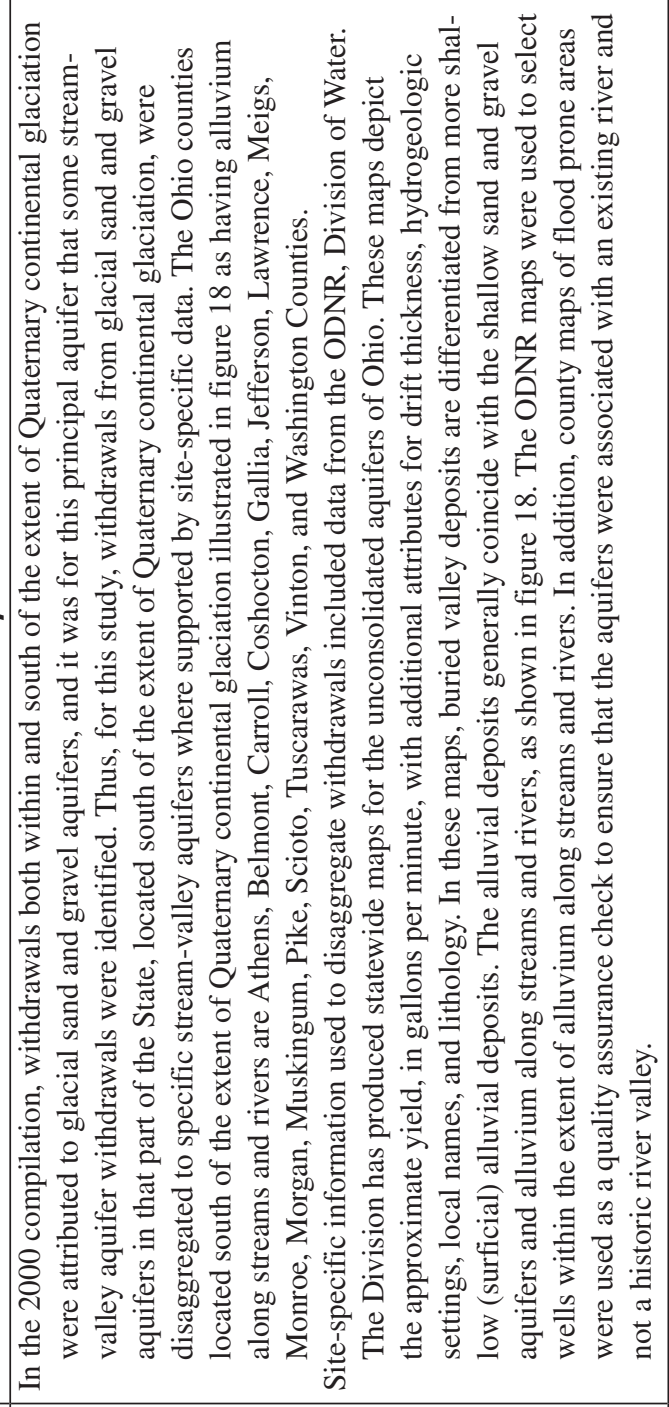 & 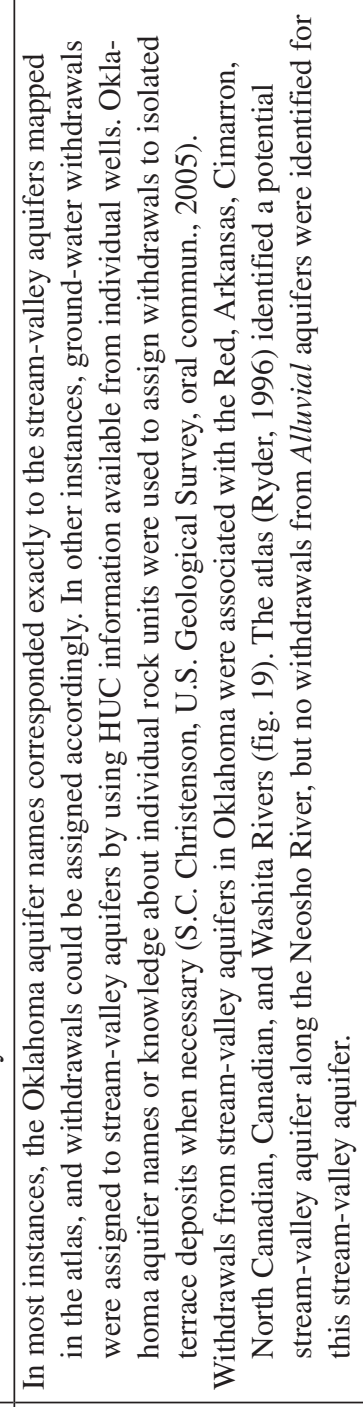 & 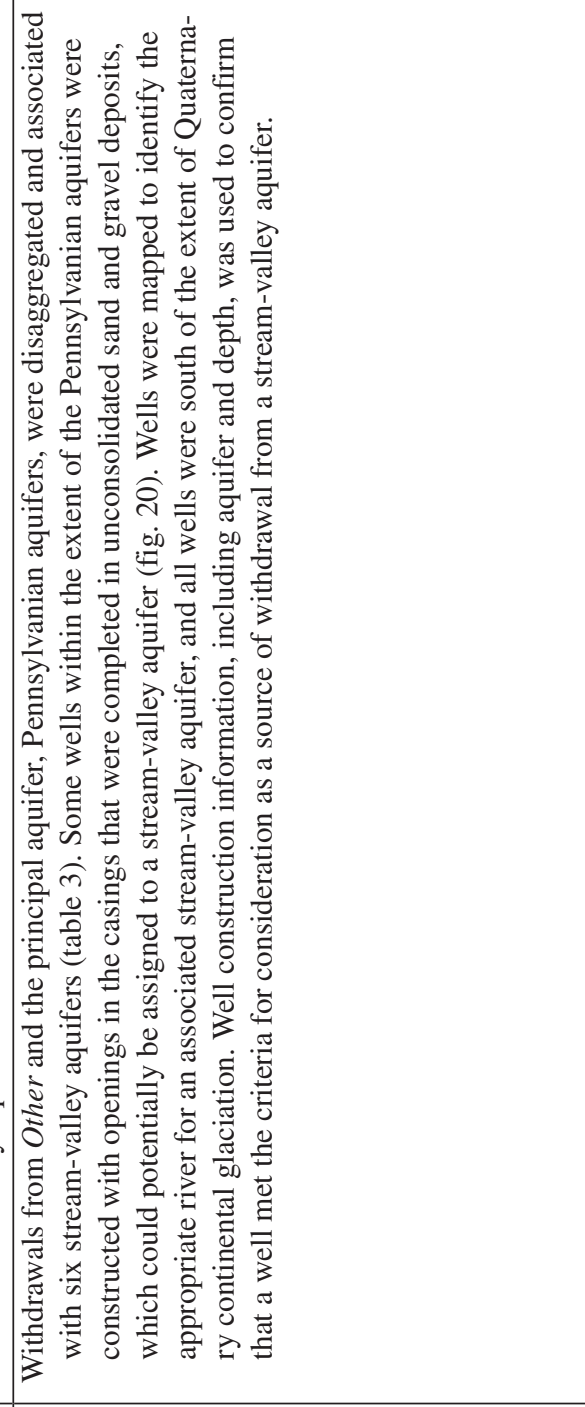 \\
\hline 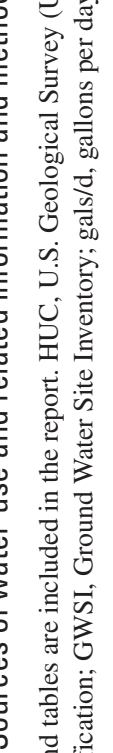 & & 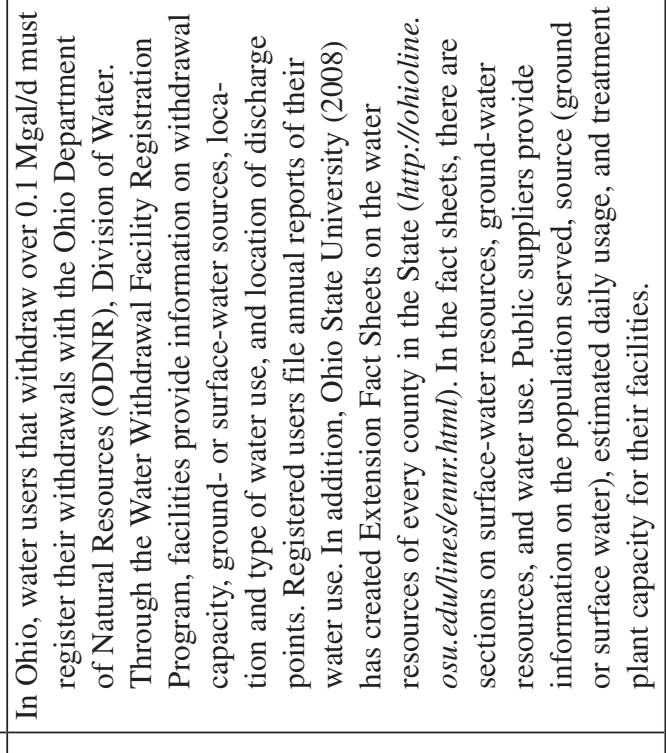 & 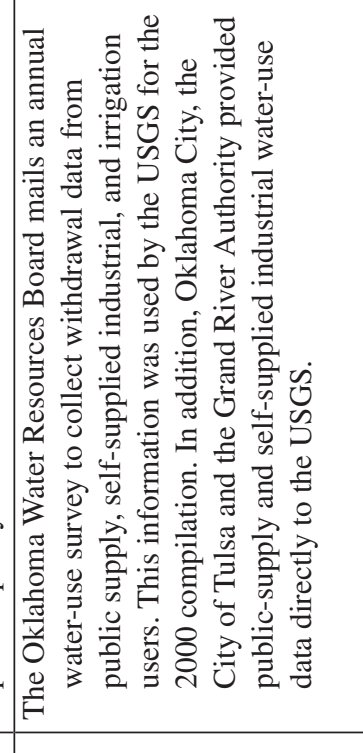 & 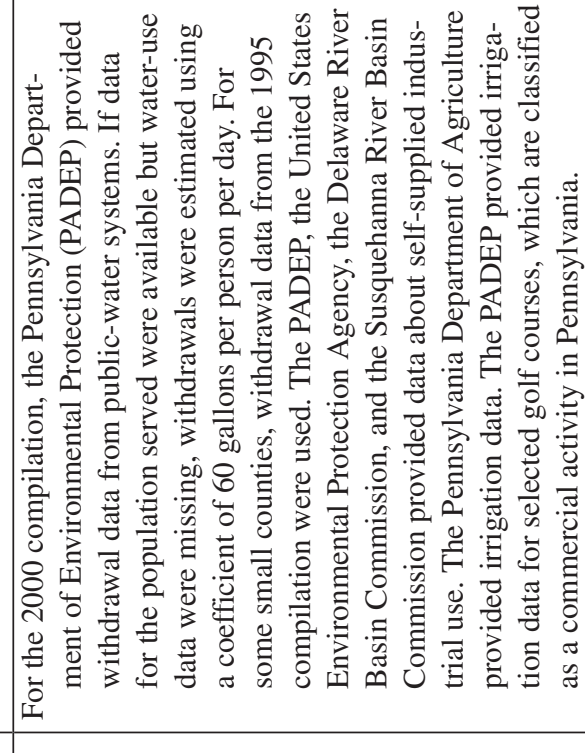 \\
\hline$\frac{3}{9}$ & 总 & & 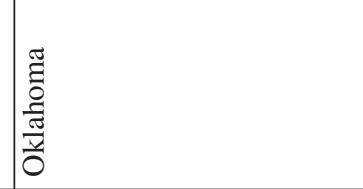 & \\
\hline
\end{tabular}




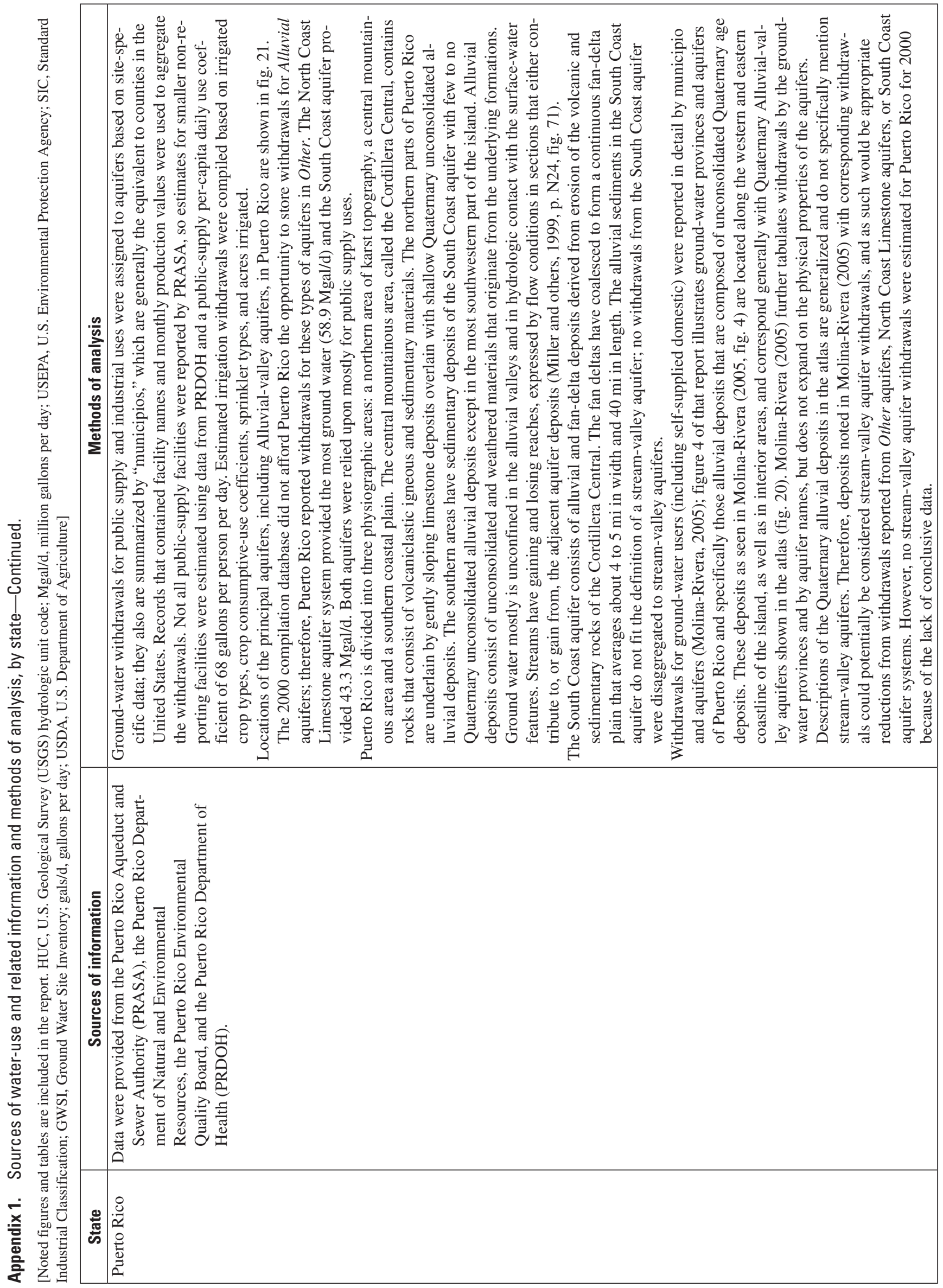




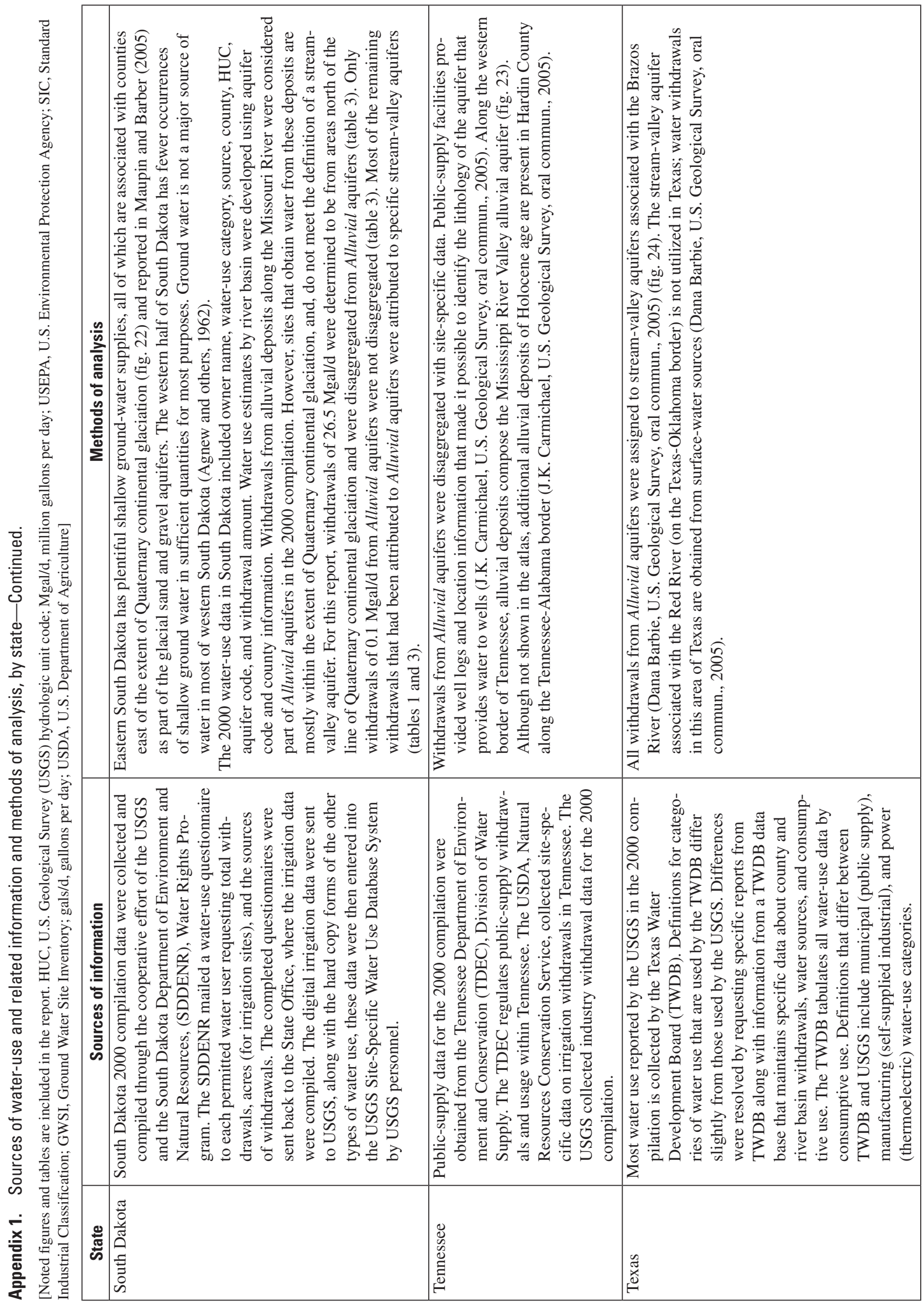


Appendix 1

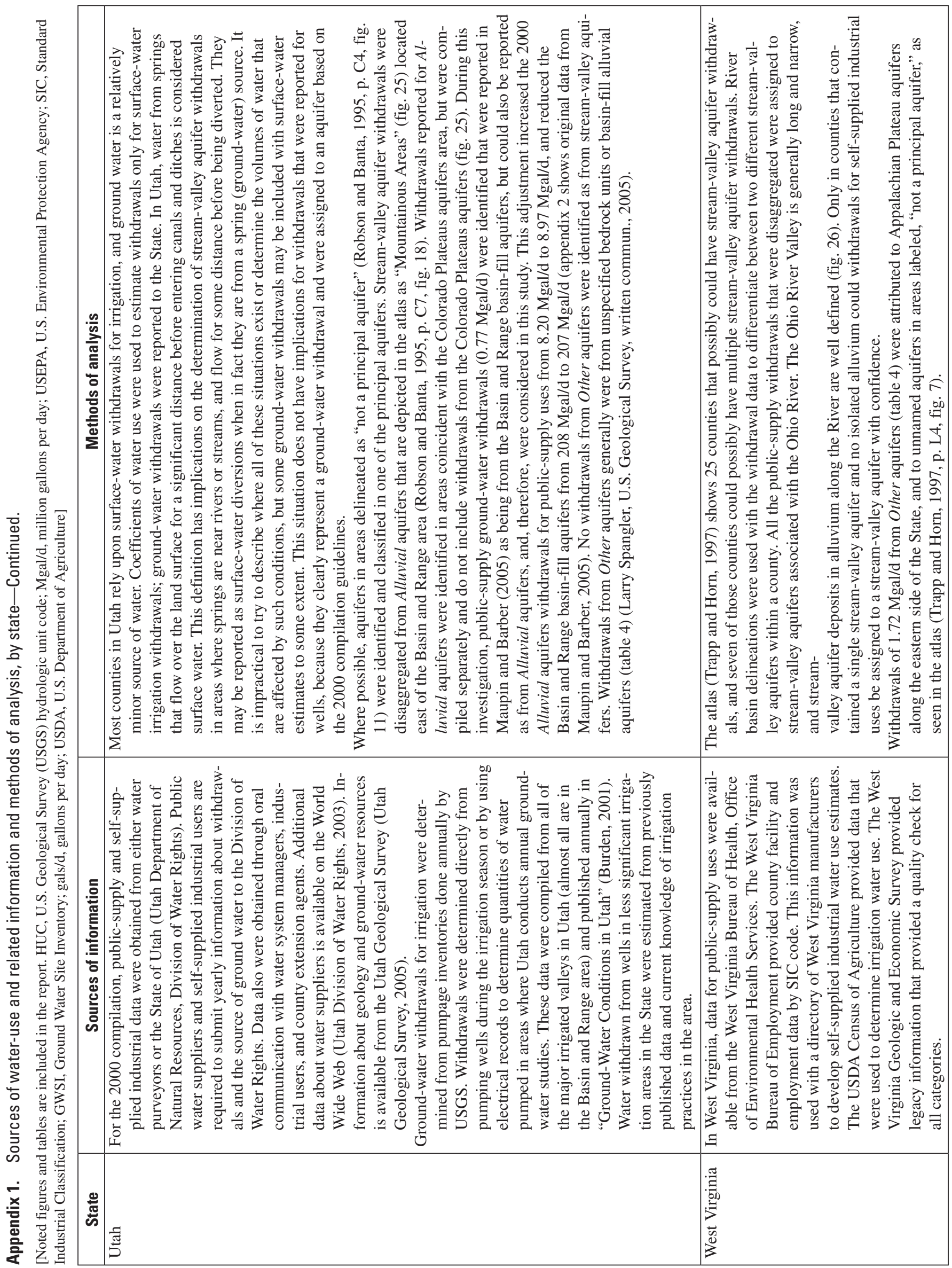




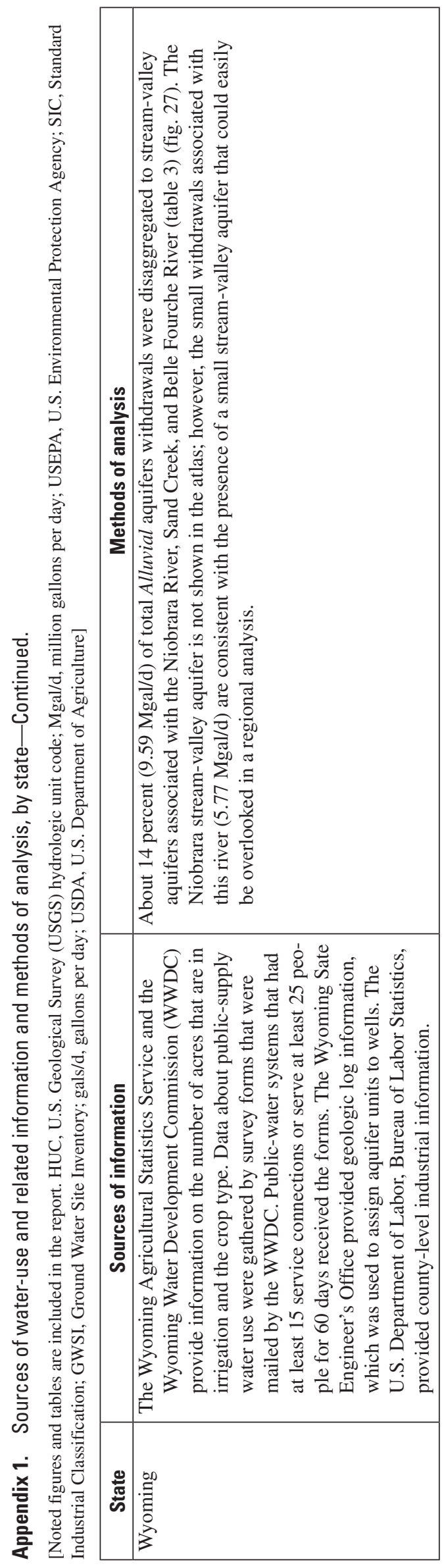


Appendix 2 
Blank Page 
Appendix 2. Estimated withdrawals for irrigation, public-supply, and self-supplied industrial uses from principal and Other aquifers in 24 States and the Commonwealth of Puerto Rico, 2000.

[Values have been rounded. Source: Maupin and Barber (2005)]

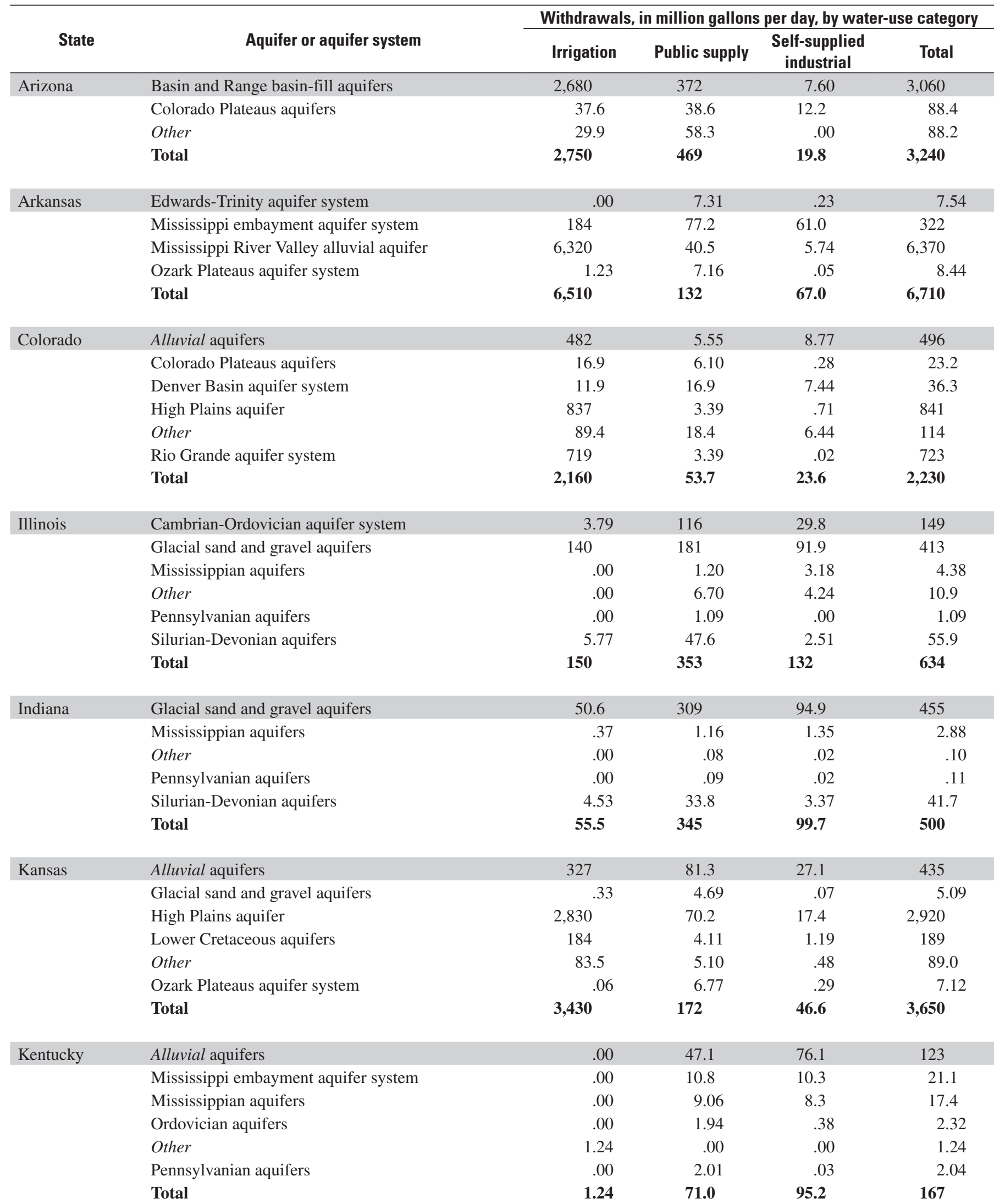


Appendix 2. Estimated withdrawals for irrigation, public-supply, and self-supplied industrial uses from principal and Other aquifers in 24 States and the Commonwealth of Puerto Rico, 2000-Continued.

[Values have been rounded. Source: Maupin and Barber (2005)]

\begin{tabular}{|c|c|c|c|c|c|}
\hline \multirow[b]{2}{*}{ State } & \multirow[b]{2}{*}{ Aquifer or aquifer system } & \multicolumn{4}{|c|}{ Withdrawals, in million gallons per day, by water-use category } \\
\hline & & Irrigation & Public supply & $\begin{array}{l}\text { Self-supplied } \\
\text { industrial }\end{array}$ & Total \\
\hline \multirow[t]{4}{*}{ Louisiana } & Alluvial aquifers & 6.62 & 0.16 & 0.00 & 6.78 \\
\hline & Mississippi embayment aquifer system & 6.26 & 64.9 & 30.9 & 102 \\
\hline & Mississippi River Valley alluvial aquifer & 221 & 7.27 & 54.3 & 282 \\
\hline & Total & 791 & 352 & 285 & 1,430 \\
\hline \multirow{6}{*}{ Missouri } & Alluvial aquifers & 59.0 & 106 & 11.1 & 176 \\
\hline & Cambrian-Ordovician aquifer system & 3.29 & 18.7 & .48 & 22.5 \\
\hline & Mississippi embayment aquifer system & .00 & 10.2 & .09 & 10.3 \\
\hline & Mississippi River Valley alluvial aquifer & 1,300 & 11.7 & 3.68 & 1,310 \\
\hline & Mississippian aquifers & 3.29 & 18.7 & .48 & 22.5 \\
\hline & Ozark Plateaus aquifer system & 19.2 & 113 & 13.4 & 145 \\
\hline \multirow{3}{*}{ Montana } & Northern Great Plains aquifer system & 4.55 & 5.84 & .58 & 11.0 \\
\hline & $\begin{array}{l}\text { Northern Rocky Mountains Intermontane Basins } \\
\text { aquifer systems }\end{array}$ & 28.3 & 33.9 & 30.5 & 92.7 \\
\hline & Total & 83.0 & 56.1 & 31.9 & 171 \\
\hline \multirow[t]{6}{*}{ Nebraska } & Alluvial aquifers & 92.2 & 50.0 & 7.68 & 150 \\
\hline & Glacial sand and gravel aquifers & 200 & 2.04 & .01 & 202 \\
\hline & High Plains aquifer & 7,050 & 191 & 25.2 & 7,270 \\
\hline & Lower Cretaceous aquifers & 73.2 & 12.8 & 1.47 & 87.5 \\
\hline & Other & 4.12 & 10.3 & 1.08 & 15.5 \\
\hline & Total & 7,420 & 266 & 35.4 & 7,720 \\
\hline \multirow{2}{*}{ New Jersey } & Valley and Ridge carbonate-rock aquifers & .12 & 9.66 & 3.07 & 12.8 \\
\hline & Total & 22.8 & 400 & 65.3 & 489 \\
\hline \multirow[t]{8}{*}{ New Mexico } & Basin and Range basin-fill aquifers & 164 & 16.6 & .08 & 181 \\
\hline & Colorado Plateaus aquifers & .59 & 12.0 & .95 & 13.5 \\
\hline & High Plains aquifer & 498 & 23.1 & 1.06 & 522 \\
\hline & Other & 66.5 & 17.0 & .38 & 83.9 \\
\hline & Pecos River Basin alluvial aquifer & .11 & 2.02 & 1.36 & 3.49 \\
\hline & Rio Grande aquifer system & 136 & 171 & 3.75 & 311 \\
\hline & Roswell Basin aquifer system & 364 & 21.1 & 1.17 & 386 \\
\hline & Total & 1,230 & 262 & 8.75 & 1,500 \\
\hline \multirow[t]{7}{*}{ New York } & Glacial sand and gravel aquifers & 16.4 & 175 & 71.6 & 263 \\
\hline & New England crystalline-rock aquifers & .17 & 7.40 & .58 & 8.15 \\
\hline & New York and New England carbonate-rock aquifers & 1.34 & 30.6 & 8.29 & 40.3 \\
\hline & New York Sandstone aquifers & .87 & 34.3 & 20.8 & 55.9 \\
\hline & Northern Atlantic Coastal Plain aquifer system & 4.28 & 326 & 28.3 & 359 \\
\hline & Other & .25 & 9.20 & 15.8 & 25.2 \\
\hline & Total & 23.3 & 583 & 145 & 752 \\
\hline
\end{tabular}


Appendix 2. Estimated withdrawals for irrigation, public-supply, and self-supplied industrial uses from principal and Other aquifers in 24 States and the Commonwealth of Puerto Rico, 2000-Continued.

[Values have been rounded. Source: Maupin and Barber (2005)]

\begin{tabular}{|c|c|c|c|c|c|}
\hline \multirow[b]{2}{*}{ State } & \multirow[b]{2}{*}{ Aquifer or aquifer system } & \multicolumn{4}{|c|}{ Withdrawals, in million gallons per day, by water-use category } \\
\hline & & Irrigation & Public supply & $\begin{array}{l}\text { Self-supplied } \\
\text { industrial }\end{array}$ & Total \\
\hline \multirow[t]{3}{*}{ North Dakota } & Alluvial aquifers & 15.6 & 4.29 & 3.25 & 23.2 \\
\hline & Northern Great Plains aquifer system & 1.59 & 3.42 & .34 & 5.35 \\
\hline & Other & 2.34 & 4.28 & .44 & 7.06 \\
\hline \multirow[t]{5}{*}{ Ohio } & Alluvial aquifers & .87 & 39.4 & 12.8 & 53.0 \\
\hline & Glacial sand and gravel aquifers & 8.20 & 312 & 101 & 421 \\
\hline & Mississippian aquifers & .00 & 119 & 38.6 & 158 \\
\hline & Other & .06 & 4.35 & 1.40 & 5.81 \\
\hline & Pennsylvanian aquifers & .00 & 2.00 & .65 & 2.65 \\
\hline \multirow{10}{*}{ Oklahoma } & Alluvial aquifers & 74.9 & 49.3 & 3.55 & 128 \\
\hline & Arbuckle-Simpson aquifer & 1.19 & 2.38 & .61 & 4.18 \\
\hline & Blaine aquifer & 19.7 & .00 & 69 & 20.4 \\
\hline & Central Oklahoma aquifer & 5.25 & 25.6 & .82 & 31.7 \\
\hline & Edwards-Trinity aquifer system & 1.96 & 2.12 & .18 & 4.26 \\
\hline & High Plains aquifer & 400 & 13.5 & .12 & 414 \\
\hline & Other & 13.3 & 5.83 & .17 & 19.3 \\
\hline & Ozark Plateaus aquifer system & .00 & 4.02 & .28 & 4.30 \\
\hline & Rush Springs aquifer & 49.7 & 6.20 & .37 & 56.2 \\
\hline & Total & 566 & 113 & 6.81 & 686 \\
\hline \multirow{4}{*}{ Pennsylvania } & Piedmont and Blue Ridge crystalline-rock aquifers & .20 & 13.2 & 7.26 & 20.7 \\
\hline & Valley and Ridge aquifers & .37 & 18.5 & 26.8 & 45.6 \\
\hline & Valley and Ridge carbonate-rock aquifers & .16 & 25.7 & 44.0 & 69.9 \\
\hline & Total & 1.37 & 212 & 155 & 368 \\
\hline \multirow[t]{4}{*}{ Puerto Rico } & North Coast Limestone aquifer system (Puerto Rico) & 5.71 & 46.8 & 6.41 & 58.9 \\
\hline & Other & 14.4 & 16.2 & 2.60 & 33.2 \\
\hline & South Coast (Puerto Rico) aquifer & 15.6 & 25.5 & 2.15 & 43.3 \\
\hline & Total & 35.7 & 88.5 & 11.2 & 135 \\
\hline \multirow[t]{7}{*}{ South Dakota } & Alluvial aquifers & 24.9 & 15.1 & .21 & 40.2 \\
\hline & Glacial sand and gravel aquifers & 90.9 & 26.4 & .17 & 118 \\
\hline & High Plains aquifer & 16.7 & 2.46 & .00 & 19.2 \\
\hline & Northern Great Plains aquifer system & .95 & 5.26 & .07 & 6.28 \\
\hline & Other & .00 & .51 & 1.39 & 1.90 \\
\hline & Paleozoic aquifers & 3.40 & 4.35 & 1.32 & 9.07 \\
\hline & Total & 137 & 54.1 & 3.16 & 195 \\
\hline
\end{tabular}


Appendix 2. Estimated withdrawals for irrigation, public-supply, and self-supplied industrial uses from principal and Other aquifers in 24 States and the Commonwealth of Puerto Rico, 2000-Continued.

[Values have been rounded. Source: Maupin and Barber (2005)]

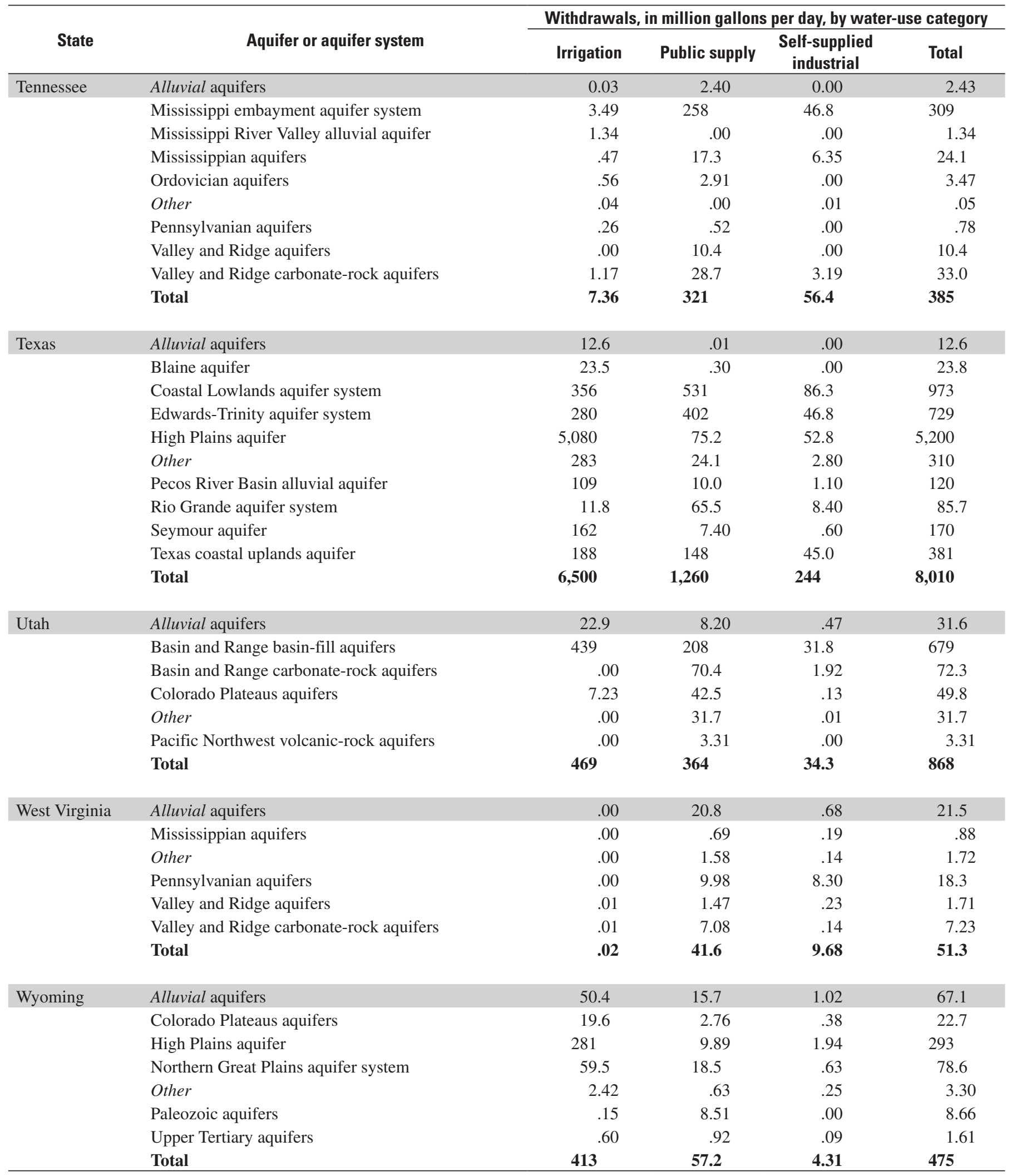


Appendix 3 
Blank Page 
Appendix 3. Estimated withdrawals for irrigation, public-supply, and self-supplied industrial uses for aquifers and aquifer units disaggregated from withdrawals from Alluvial aquifers north of the extent of Quaternary continental glaciation in North Dakota, 2000.

[Values have been rounded]

\begin{tabular}{|c|c|c|c|c|}
\hline \multirow{2}{*}{ Stream, river, or aquifer name } & \multicolumn{4}{|c|}{ Withdrawals, in million gallons per day, by water-use category } \\
\hline & Total & Irrigation & Public supply & Self-supplied industrial \\
\hline Lower Apple Creek & 0.16 & 0.05 & 0.00 & 0.11 \\
\hline Cattail & .00 & .00 & .00 & .00 \\
\hline Denbigh & .94 & .59 & .20 & .15 \\
\hline Elliot & .19 & .19 & .00 & .00 \\
\hline Glencoe Channel & .00 & .00 & .00 & .00 \\
\hline Guelph & 1.07 & .76 & .31 & .00 \\
\hline Heart River aquifer & .01 & .00 & .01 & .00 \\
\hline Hofflund & .13 & .13 & .00 & .00 \\
\hline Knife River & 2.69 & .00 & .03 & .00 \\
\hline Little Knife River & .38 & .38 & .00 & .00 \\
\hline Lower Souris & .11 & .11 & .00 & .00 \\
\hline Martin & .43 & .43 & .00 & .00 \\
\hline McVille & .01 & .00 & .00 & .01 \\
\hline Midway & 7.47 & 6.32 & 1.15 & .00 \\
\hline Milnor Channel & .02 & .02 & .00 & .00 \\
\hline Missouri River & .07 & .07 & .00 & .00 \\
\hline Shell Creek & .69 & .17 & .51 & .01 \\
\hline Shell Valley & .04 & .00 & .03 & .01 \\
\hline Sheyenne Channel & .52 & .00 & .32 & .20 \\
\hline Strasburg & .42 & .00 & .42 & .00 \\
\hline Strawberry Lake & .03 & .03 & .00 & .00 \\
\hline Tobacco Garden Creek & .07 & .00 & .07 & .00 \\
\hline Wahpeton Buried Valley & .13 & .13 & .00 & .00 \\
\hline Windsor & .03 & .00 & .03 & .00 \\
\hline Total & 23.2 & 15.6 & 4.29 & .59 \\
\hline
\end{tabular}


Publishing support provided by: Lafayette Publishing Service Center 